\title{
ISSUES ON WAR \& PEACE: PROCEEDINGS OF THE 14TH BIENNIAL LABOUR HISTORY CONFERENCE
}

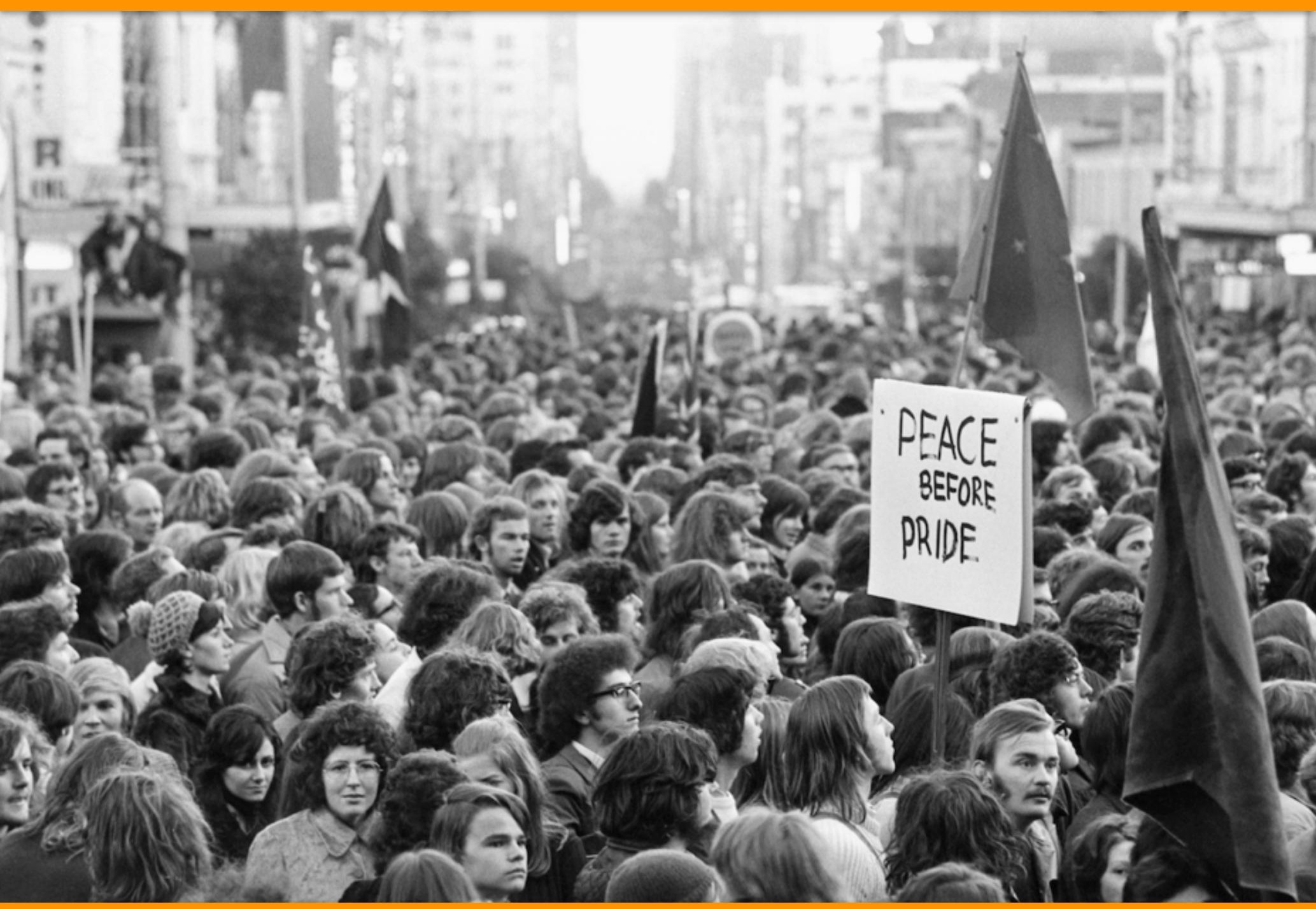

EDITED BY PHILLIP DEERY AND JULIE KIMBER 
WWW.LABOURHISTORYMELBOURNE.ORG

AUSTRALIAN SOCIETY FOR THE STUDY OF LABOUR HISTORY

MELBOURNE, AUSTRALIA

COPYRIGHT ${ }^{\oplus}$ AUSTRALIAN SOCIETY FOR THE STUDY OF LABOUR HISTORY 2015

OUR COVER IMAGE WAS TAKEN BY GRAHAM HOWE AT THE 1971 MORATORIUM TO END THE WAR IN VIETNAM. IT IS USED HERE WITH GRAHAM’S PERMISSION. COPYRIGHT REMAINS WITH THE PHOTOGRAPHER ${ }^{\circledR}$ GRAHAM HOWE 2014.

ALL RIGHTS RESERVED. EXCEPT AS PERMITTED UNDER THE ACT (FOR EXAMPLE A

FAIR DEALING FOR THE PURPOSES OF STUDY, RESEARCH, CRITICISM, OR REVIEW) NO

PART OF THIS PUBLICATION MAY BE REPRODUCED, STORED IN A RETRIEVAL SYSTEM,

COMMUNICATED OR TRANSMITTED IN ANY FORM OR BY ANY MEANS WITHOUT

PERMISSION FROM THE PUBLISHER AND/OR INDIVIDUAL AUTHORS.

ISBN: 978-0-9803883-3-6. 


\section{INTRODUCTION}

These proceedings carry some of the papers delivered at the 14th Biennial Labour History Conference, 11-13 February 2015. Titled Fighting Against War: Peace Activism in the Twentieth Century, the conference was held at the University of Melbourne. A conference book of refereed papers has been published under that title and these proceedings carry the non-refereed papers received for publication. There is one exception to that rule: the paper written by Warwick Eather and Drew Cottle, published below, which underwent double blind refereeing. It is an important paper, which demonstrates with compelling evidence that the rabbit was anything but a curse to the many men, women, and children who took advantage of the rabbit industry's resilience during the economic storms for much of the twentieth century. It exemplifies how meticulous research in labour history can provide an entirely new understanding of an otherwise much-maligned animal in Australia.

The next three papers all concern opposition to nuclear testing, from the 1950s to the 1980s. When read together, they provide a convincing argument for the importance and efficacy of the diverse anti-nuclear movements in Australia, New Zealand and the Pacific Islands. Whilst there are inevitable overlaps, these papers emphasise different and often neglected dimensions: the struggle for recognition of and compensation for the devastating effects of nuclear testing; the internal dynamics of the various nuclear disarmament organisations; and an evaluation of their impact on government policy, culminating in the Rarotonga Treaty of 1985.

The last three papers cover aspects of World War I, the Cold War, and the Vietnam War. The first focuses on the role of one redoubtable woman, Ettie Rout, in challenging popular misconceptions about venereal disease held by military authorities and the soldiers themselves. The next paper examines the life of a Czech Lutheran pastor, Professor Josef Hromádka, who visited Australia twice during the 1950s. Hromádka attempted to juggle Christianity with Socialism, which - in the prevailing climate of strident anti-communism - provoked hostile receptions and Cold War invective. The final paper in this collection brings to life, through the reflections of a "participant observer", the preparations, conduct and impact of Adelaide's largest anti-war demonstration: the protest against the invasion of Iraq in 2003 organised by the NoWar collective. Its efforts, undertaken by a broad range of rank and file activists, is a fitting reminder, and exemplar, of the theme of our conference: peace activism in the twentieth century.

Phillip Deery and Julie Kimber 


\section{CONTENTS}

1

THE RABBIT INDUSTRY IN SOUTH-EAST AUSTRALIA, 1870-1970

WARWICK EATHER AND DREW COTTLE

21

GRAPPLING WITH THE BOMB: OPPOSITION TO PACIFIC NUCLEAR TESTING IN THE 1950S

NIC MACLELLAND

39

THE AUSTRALIAN NUCLEAR DISARMAMENT MOVEMENT IN THE 1980S

JONATHAN STRAUSS

51

antinuClear Campaigning and the SOUth PaCiFic Nuclear-Free Zone (Rarotonga) Treaty, 1960-85

MICHAEL HAMEL-GreEN

63

VENEREAL DISEASE IN WORLD WAR I

JEANETTE DEBNEY-JOYCE

70

WORKER FOR PEACE FROM BEHIND THE IRON CURTAIN

DORIS LEROY

83

“Today We OWN the Streets”: The Adelaide NoWar Rally OF 16 FEBRUARY 2003. A PARTICIPANT OBSERVER MEMOIR DAVID FABER 
Warwick Eather and Drew Cottle, "The Rabbit Industry in South-East Australia, 1870-1970", Proceedings of the 14th Biennial Labour History Conference, eds, Phillip Deery and Julie Kimber (Melbourne: Australian Society for the Study of Labour History, 2015), 1-20. ISBN: 978-0-9803883-3-6.

\title{
The Rabbit Industry in South-East Australia, 1870-1970
}

\author{
Warwick Eather and Drew Cottle*
}

In 1929 the rabbit industry was reported to be the largest employer of labour in Australia. During the hundred years covered by this paper, over 20 billion rabbits were trapped or poisoned in southeast Australia for commercial purposes. Each rabbit carcase or skin was worth money. Carcase prices varied from $3 d$ a pair in the 1890s to $24 d$ a pair in the early 1950s, while skins were worth between $1.5 d$ and $10 d$ a pound in the 1890s and reached $249 d$ a pound in 1946. Thousands of rabbiters in New South Wales, Victoria, Tasmania, South Australia and southern Queensland earned in a week up to ten times the rates of pay earned by building and metal industry tradesmen, and earnings remained high until 1970. Trappers were independent suppliers who chose when to work, how long to work, what to work for, skins or carcases, or a mixture of both, and who to sell to. Unlike other rural workers, who had to travel continuously in search of seasonal or intermittent work, rabbiters were able to reside in one location all year. The rabbit industry revolutionised work practices in rural areas and stimulated local businesses like no other industry. Wool remained the nation's major export earner but income from wool ended up in relatively few hands, while the rabbit industry provided cash money on a daily basis to thousands of trappers and workers. This money was spent locally in hundreds of rural businesses, used to buy cars, homes and farms, or saved. Unlike other rural industries, the rabbit industry prospered during war, depression and drought.

By the late 1920s the rabbit industry in south-eastern Australia (southern Queensland, New South Wales (NSW), Victoria, Tasmania and eastern South Australia) was one of the largest employers of labour in the country. Over 20,000 trappers worked full-time trapping for carcases or skins, or poisoning for skins. Thousands were employed in numerous freezer works located in rural towns and capital cities, grading, sorting, packing, skinning and transporting carcases by the tens of millions. Thousands more were employed by the multitude of skin buying firms located throughout rural areas and in capital cities. Hundreds sold rabbits in the streets of cities or worked in small goods shops that retailed rabbits. Nearly 10,000 workers made felt hats out of rabbit skins, pine boxes for the rabbit export trade, gelatine from skin scraps, and fertilizer and animal feed from the remains of rabbits unfit for human consumption. ${ }^{1}$

The focus of this paper is on the commercialisation of the rabbit and how the rabbit industry became an economic powerhouse in rural Australia. The central argument is that the export of preserved rabbit meat, rabbit skins and frozen carcases, and major increases in rates of local consumption established and enlarged the industry. Also important is the dramatic economic impact the industry had on rural workers and the communities they lived in. The paper highlights that instead of poorly paid seasonal work, unskilled and semi-skilled rural workers who trapped had well paid employment all year and earned large amounts of money. This money was spent in local businesses. Workers could reside in one location and did not have to travel continuously in search of paid work. The paper also shows that urban-based workers in many different occupations rushed to enter the industry. Trappers, as independent suppliers, chose when to work and for how long, whether to work for skins or carcases or both, and who to sell to. After the literature review and a brief account of the introduction of the wild rabbit, the paper 
analyses the preserving industry, the skin and carcase export trade, local consumption and the financial benefits enjoyed by the trappers and the communities they lived in.

This paper is part of a larger project that is on going. Papers on specific topics such as the rabbiters and the wider working experience, the conflict over land use between farming and grazing interests and the rabbit industry, the Danysz experiments during 1906 and 1908, class, power and status relationships in rural towns, the benefits of the industry to the rural economy, and the rabbit industry in the nineteenth century have been submitted to academic journals or are in the process of being written.

\section{Literature Review}

The rabbit as a pest is one of the most studied topics in Australia. Scientists seeking answers as to how to stop the spread of rabbits and how to eliminate them entirely began their research in the 1880 s and it continues today. There is no need to review the scientific literature other than to say it exists as none of it moves beyond the rabbit as a pest. ${ }^{2}$ Over the last 90 years, James Matthams (1921), David Stead (1928), Eric Rolls (1969), Rae Pennycuick (1995) Brian Coman (1999) and Stephen Dando-Collins (2008) have all published work on the rabbit as a pest that includes sections on the rabbit industry. They all regard the industry in a negative light and argue that commercialisation has produced more harm than good. ${ }^{3}$

The most comprehensive study of the rabbit industry is L.J. Dunn's 1948 economic survey compiled for the Federal government's Bureau of Agricultural Economics. Dunn lists all the major groups in the industry from its inception and provides detailed statistics on the carcase and skin export trade from 1904 to 1948 for each state and the commonwealth. There is little analysis of the industry and its impact on individual trappers and the communities in which they lived and worked. ${ }^{4}$

Other secondary sources have touched on aspects of the rabbit industry. Catherine Watson's 1996 biography of Jack McCraith shows that McCraith started buying and selling rabbits as a 15-year-old in Melbourne in the early 1930s and by the late 1940s his company was one of the largest exporters of rabbits in Victoria (over 130 million rabbits were exported during nearly 40 years of operations). The study highlights how McCraith grew his business and its profitability (he was a millionaire by the early 1950s), the work done in the factory and the relationship between McCraith and his workers and trappers. Watson shows that while myxomatosis killed millions of rabbits after its release in 1951 it did not kill the rabbit industry. After 1951 McCraith sourced his rabbits from central Australia, an area that was too dry for the virus carrying mosquitoes, and continued to export until the early $1970 \mathrm{~s}^{5}$

G.B. Eggleton's 1982 study of rabbiters and the industry in the Mildura area during the first half of the twentieth century is a positive study of the trapper and the rabbit industry. Eggleton emphasises how the rabbit industry was one of the more profitable businesses in Mildura during the 1929-32 Depression. He believed the industry was a far better solution to the rabbit "problem" than either poisoning or myxomatosis. The wider impact of the industry on rural life is not discussed. ${ }^{6}$

In 2010, the Australian Broadcasting Commission published a book of stories about rabbits and life in rural Australia that had been sent to Radio Australia as part of the station's "Rabbiting On" storytelling competition. While entertaining, the stories add little to the story of the rabbit industry. ${ }^{7}$ Publications on the stock and station agent industry in Australia, the Australian Mercantile Land and Finance Company, and life in the nineteenth century add little to this study. ${ }^{8}$ Studies of the manufacturing industries linked to the rabbit industry are scarce. C.B. Schedvin's pioneering work published in 1967 on Lysaght Brothers and Company Proprietary Limited and the production of rabbit proof fencing highlights the rapid growth in demand for this product and how Lysaght supplied up to two-thirds of local demand. ${ }^{9}$ K.T.H. Farrer in his 1980 
study of food technology in the nineteenth century provides little more than a summary of the rabbit preserving industry. ${ }^{10}$ Academic publications on the wool industry add little to this study. ${ }^{11}$

The trapping and poisoning of the rabbit for its fur was one part of a very large skin and fur industry. The possum, kangaroo, koala, wallaby and fox were also hunted. N.L. Howlett has highlighted how in Queensland from 1915 to the late 1920s large numbers of koalas were slaughtered each year and the trappers/shooters made very good money. The Queensland government supported koala hunting because it employed surplus labour in rural towns and benefited local businesses. The hunts stopped in the late 1920s after the government came up against an increasingly vocal environmental lobby. ${ }^{12}$

\section{The Rabbits}

Rabbits are not native to Australia. Five rabbits arrived with the first fleet in 1788 and a second consignment from Capetown arrived in 1791. By the mid-1820s rabbits were breeding around houses in Sydney. Wild rabbits were released in Tasmania in the early 1820 s and by 1824 a firm in Hobart was manufacturing felt hats out of rabbit skins. On the mainland the Hentys "imported" rabbits to Swan River in 1829 and to Portland in 1834, while rabbits were recorded in Adelaide in 1837 and around Ballarat in $1839 .{ }^{13}$ Thomas Austin imported wild rabbits in 1859 and bred them at his property at Barwon, near modern day Geelong, for hunting. Austin was one of many landowners breeding rabbits at this time. Within eight years the offspring of Austin's rabbits were located at Barwon Heads, 35 miles away, and north-west of Winchelsea on the Bellarine Peninsular. In the early 1890s rabbits were in plague proportions in western Victoria around Colac, Hamilton, Portland and Warrnambool, and in south-east South Australia around Mount Gambier. ${ }^{14}$ In Sydney in the early 1860s, Thomas Holt bred rabbits at his Marrickville property on the Cook's River. Within 20 years the offspring had spread west to Camden and south to Bulli. ${ }^{15}$

Settlers often carried rabbits over long distances and released them. In 1862 rabbits were taken to the New England area of NSW, in 1866 two settlers near Donald in Victoria released four pairs and they flourished, and there were two significant releases in the 1870s, in the Kapunda district in South Australia and around Wentworth and Balranald in NSW. ${ }^{16}$ The releases at Wentworth and Balranald were decisive:

Wentworth is at the junction of the Murray and Darling Rivers. Balranald is on the Murrumbidgee. Putting a pair of rabbits on a river-bank is like putting a passenger on a slow train. Eventually and almost certainly he will reach the end of the line ... The Darling was a broad track to Queensland; and the Murrumbidgee and its tributary, the Lachlan, were signposts to the centre of New South Wales. ${ }^{17}$

The rabbits spread north and north-west reaching the rabbit proof fence on the Queensland-NSW border by 1891, Dubbo and Coonamble in 1898, Armidale in 1903 and Boggabri around 1905. ${ }^{18}$ They also spread eastwards along the rivers; millions of rabbits were being caught around Wagga Wagga in the 1890s. ${ }^{19}$ In 1895, at the beginning of the eight-year Federation Drought, dead rabbits were found two-feet deep along fences west of Nyngan in western NSW and gates couldn't be opened until the dead had been scrapped away. ${ }^{20}$

\section{Commercialisation}

Commercialisation of the rabbit commenced in the first half of the nineteenth century but it only became important after 1870 . Rabbits priced between $4 \mathrm{~s} 6 \mathrm{~d}$ and $8 \mathrm{~s}$ a pair were being sold in markets in Sydney, Melbourne, and Adelaide during the 1840s and 1850s. The Melbourne trade grew rapidly from the early 1870s. Trappers from Bacchus Marsh sent over 200 tons of carcases (approximately 150,000 rabbits) to the Melbourne Fish Market between 1872 and $1874 .{ }^{21}$ During 
the winter of 1875, trappers from Colac sent 8,000 rabbits a week to markets in Melbourne, Geelong and Ballarat. ${ }^{22} \mathrm{~A}$ rabbit preserving factory was established at Colac in 1871 and, despite several closures, canned over 6,650,000 rabbits in its 15 years of operations. ${ }^{23}$ In Tasmania bales of skins were exported from the 1830s. During the 1870s the colony exported around 650,000 skins a year, with a Hobart firm making $£ 5,000$ a year out of the trade. ${ }^{24}$ In Melbourne in the 1860 s, an unknown journeyman hatter who had served his time at a leading London hat manufacturer began buying quantities of skins and exporting them to London. By the end of the 1870s the colonial trade in rabbit skins was substantial, with over 3 million skins auctioned in London in 1878 and close to 6 million skins in $1879 .{ }^{25}$ The number of establishments in Victoria making hats doubled between 1870 and 1880. In one year in the mid-1880s a Melbourne firm manufacturing felt hats spent $£ 2,500$ purchasing 240,000 rabbit skins at an average price of 2 s $6 \mathrm{~d}$ a dozen. Joesph Bidencope's hat factory in Hobart used 350,000 rabbit skins a year from 1874 until it closed in the late 1890s. ${ }^{26}$ In 1882, J.D. Fitzgerald, a rabbit skin buyer employed by Messrs Charles Cox and Company, a Melbourne firm that was buying skins for export, argued in letters to regional Victorian newspapers for greater commercialisation of the rabbit. He wrote that poisoning rabbits in their burrows was wasteful and costly; the skin could be used to make hats, gloves, fake furs, glue, and for stuffing bed mattresses, while the carcase could be eaten by humans or used for poultry and pig feed; the manufacture in Victoria of felt hats would offset a large part of a yearly import bill of over $£ 200,000$ for felt and like products; and trapping would pay well with skins at $1 \mathrm{~s} 8 \mathrm{~d}$ to $2 \mathrm{~s}$ a dozen. ${ }^{27} \mathrm{His}$ argument was ignored: colonial politicians and landowners were determined to exterminate the rabbit not to commercialise it.

Parliaments from Queensland to South Australia attempted to legislate the rabbit away. Tasmania passed the first act in 1871, South Australia followed in 1875, Queensland and Victoria in 1880 and NSW in 1883. All legislation made it compulsory for landholders to destroy all rabbits on their farms and stations and made it illegal to aid the spread of the rabbit. The NSW, Victoria, South Australia and Queensland governments funded the erection of rabbit proof fences along colonial borders and within colonies. The 648 mile fence erected between 1886-90 along the Queensland and NSW border cost the Queensland government $£ 123,000$ to erect and $£ 11,000$ a year to supervise and maintain, while the NSW government spent $£ 69,808$ on 1,330 miles of rabbit proof fencing from 1883 to June 1905. Given that the fences did not stop the rabbits, they were costly failures. The Victorian Act paid for the destruction of rabbits on crown lands, and payment of up to 1 s $9 \mathrm{~d}$ per dozen skins cost the government over $£ 414,000$ to 1903 . The 1883 Act in NSW compelled the government to pay three-quarters of all costs related to killing the rabbits, with landholders or leaseholders to pay the final quarter. By 1890 the government and landholders had paid trappers $£ 1,543,000$ for rabbit scalps at a penny each. ${ }^{28}$

\section{Preserved Rabbit}

Commercialisation of the rabbit continued during the last two decades of the nineteenth century despite opposition from governments and landholders. The meat preserving industry was at the forefront of this growth. In addition to its Colac works, the Colac Meat Preserving Company opened a branch factory in Camperdown in 1881, which treated up to 1 million rabbits from April to October each year. Up to 90 men and boys worked in the factory and between 200 and 300 trappers supplied it. ${ }^{29} \mathrm{~A}$ Melbourne syndicate headed by Robert Inglis, a landowner in western Victoria, formed the Stonyford Pastoral and Preserving Company in 1884 and commenced work at Stonyford in March 1885 in competition to the Colac firm. It treated a minimum of 600,000 rabbits each year. ${ }^{30}$ Inglis was the prime mover behind the establishment of a factory in Hamilton in 1892, which during its first six months purchased 960,000 rabbits. High railway freights and lack of sales lead to its closure in mid-1893. It reopened as a co-operative in 
February 1895, following a concerted campaign by local landholders and businessmen. Profits from buying and canning 1 million rabbits a year were small, sale of the canned product normally just covered costs, while sale of the skins generated the profits, but the co-operative venture paid dividends of between 10 and 25 per cent a year until the early twentieth century. ${ }^{31}$ The Euroa/Longwood, Port Fairy, and Portland works each purchased between 400,000 and 750,000 rabbits a year during the $1890 \mathrm{~s}^{32}$ The works in Victoria canned 2,800,000 rabbits in 1896, and similar numbers were recorded before and after this date. ${ }^{33}$

In South Australia preserving works were first established by the Northern Rabbit Meat Preserving Company between Kapunda and Eudunda in 1877. The company purchased 45,000 rabbits a month until the factory closed in $1879 .{ }^{34}$ In June 1897, the Mount Gambier Rabbit and Meat Preserving Company opened works at Compton. The company operated for just under 20 years and during peak times purchased around four million rabbits a year. ${ }^{35}$ In 1896 five southeastern District Councils opened a factory at Millicent to combat the rabbit, reduce expenditure on rabbit destruction, and generate local employment and business activity. It was taken over by a private company on 5 May 1897. The following two years were hectic with large orders warranting larger purchases of rabbits and the working of double shifts in the factory. ${ }^{36}$ Factories were also located at Robe and Port Augusta, both of which operated for a short time. ${ }^{37}$

Preserving rabbits was not as popular in NSW despite the plenitude of rabbits. The Bourke Meat Preserving Company, the Menindee Boiling Down, Freezing and Meat Preserving Company Limited, located in Menindee on the Darling River in western NSW, and the Euroa Preserving Company's factory at Whitton, a small township located north-west of Wagga Wagga, preserved rabbits for the local and export markets during the 1890s. All three works canned for short periods but production at all sites stopped in the late 1890s due to a shortage of water, a consequence of the Federation Drought. ${ }^{38}$

The preserving industry struggled in the first two decades of the twentieth century. It could not compete with the frozen carcase trade and was badly affected by the 1906 Chicago meat scandal, where meat-producing factories were guilty of "using foul or diseased waste meat to make cheap products." In response, the English public briefly stopped buying preserved meats, which closed the industry's largest market. Large military orders from Japan (1904), the British Admiralty $(1908,1910)$ and from the British and Australian governments during World War I sustained the industry. Factories in south-east South Australia, Victoria and in NSW at Wyndham (1911-12), Berrima (1913) and Merriwa (from 1917) produced the canned rabbit. ${ }^{39}$ Most works had closed by 1920 and the British Admiralty removed preserved rabbit from its list of service provisions in $1922 .{ }^{40}$ Modern authors have condemned the quality of the preserved rabbit given the rudimentary production methods used in the late nineteenth and early twentieth centuries, but the contents of a tin produced in Mount Gambier in 1910 was consumed by boarders and guests at the town's Federal Hotel in 1944 and "all were loud in praise of the quality of the meat." 41

\section{The Skin Trade}

During the 1890s Victoria exported between 6 million and 10.5 million skins a year (skins from western NSW were "imported" through Echuca and "exported" through Melbourne) and Tasmania exported between 3 and 4 million skins a year over the decade, while in 1894 South Australia exported 835,086 skins. ${ }^{42}$ Local sales commenced in Sydney, Melbourne, and Adelaide and prices ranged between $9 \mathrm{~d}$ to $18 \mathrm{~d}$ a dozen skins or $1.5 \mathrm{~d}$ to $10.75 \mathrm{~d}$ a pound. ${ }^{43}$ The skins were sourced from a wide area of the south east. In 1891, at Terowie, a settlement 220 miles north of Adelaide, one settler accumulated 25,000 skins during the year and sold them for approximately $£ 78 .{ }^{44}$ During January and February 1893 , Mr C.J. Miller, the managing director of the Riverina 
Skin and Hide Purchasing Company Limited at Hay, in south-western NSW, spent $£ 60115 \mathrm{~s} 0 \mathrm{~d}$ purchasing 288,604 rabbit skins at $6 \mathrm{~d}$ a pound. Other buyers from Sydney, Melbourne and overseas were also in Hay "competing for the various large parcels very keenly," and purchased a further 300,000 rabbit skins. At this time 200,000 skins were purchased in Whitton. ${ }^{45}$ Close to 150,000 skins were purchased at Warrnambool, in western Victoria, during 1893 at $18 \mathrm{~d}$ a dozen and by 1895 the trade was worth $£ 5,000$ a year. ${ }^{46}$ The Harrow correspondent for The Horsham Times, reported in May 1899 that, "rabbit trapping is the chief industry in our district at present. Trappers are at work on all the stations, and seem to be making very good wages ... They are trapping chiefly for skins, which are bringing high prices." ${ }^{\prime 7}$

The trade in rabbit skins grew rapidly in the 20 century. Figures provided by Dunn show that $411,867,000$ pounds of skins (approximately four billion skins) were exported between 1904 and 1947. After 1905 just over 67 per cent (278,355,000 pounds) of the skins went to America, while Great Britain accounted for most of the remainder. Each year the trade accounted for between 10 and 28 per cent of total exports to America. Among other uses, American companies treated the skins with various processes and chemicals and made them resemble more expensive furs and exported the finished product. Large quantities of fake furs and fur coats were imported into Australia and sold at exorbitant prices to the unsuspecting and naïve, many of whom were wealthy members of the local elites. Local hat and furrier manufacturers took between 20-25 per cent of all skins each year, and for the period 1904-47 they purchased around 1 billion skins. Offerings at the fortnightly Sydney auctions regularly exceeded 100 tons of skins. Prices fluctuated wildly from lows of 1.5d a pound to highs during 1918-20,1926-29, 1935-39 and 1941-49 of between $120 \mathrm{~d}$ to $249 \mathrm{~d}$ a pound (in 1946 rabbit skins made a $£$ a pound, six years before wool did the same thing). ${ }^{48}$

Skin buyers made big money. Local store owners in Victoria started buying large quantities of rabbit skins in the 1870s and made excellent profits, which prompted a number of shire councils in the colony to enter the trade in the early 1880s. The Bacchus Marsh Shire Council, for example, started buying in 1882 but lost over $£ 130$ in the first year, which convinced the majority of councillors to accept an offer from Tait, Smith and Company of Melbourne to take over the local trade. ${ }^{49}$ Storekeepers in NSW followed the lead of their Victorian counterparts in the twentieth century. After taking over the family store in Bungendore in 1902, Albert Daniels spent $£ 8,000$ buying over one million skins over the next four years. Daniels made substantial profits from these purchases, which enabled him to buy larger premises in Bungendore and to make other investments. He continued to buy skins and trade in Bungendore until, as a wealthy man, he and his family relocated to Sydney in October 1913. During 1906 Daniels' counterpart at Bimbi, a small town located near Young, paid out "over $£ 70$ [on one day and] is in the habit of paying out large sums for rabbit skins almost daily," while Mr J. Morgan, the storekeeper in Boomey, a small town located to the north-east of Molong, started "buying rabbit skins on a large scale, and the trade is opening up." ${ }^{\text {" }}$ Mr H.L. Tebbutt, a "prosperous Boggabri storekeeper" who still worked in his shop in his late eighties, told Eric Rolls in the mid-1960s how the profits from buying rabbit skins had enabled him to purchase his shop. ${ }^{51}$

At Wagga Wagga, Edward Collins established a skin merchant business in the town in 1903 and he regularly travelled by train between Wagga Wagga and Goulburn buying rabbit skins at every railway station along the way. Over a four month period in 1904 he spent $£ 5,800$ to purchase over 90 tons of skins (approximately 1.3 million skins). Collins or an employee repeated these trips each year until he opened branch offices at Murrumburrah and Yass, and he continued to trade in rabbit skins up until his death on 8 April 1936. It made him a wealthy man and an influential member of the Wagga Wagga community. ${ }^{52}$ Collins's counterparts in Wellington and Dubbo in mid-western NSW paid out over $£ 500$ a week for rabbit skins during $1905 .{ }^{53}$ 
Collins and his skin buying compatriots either sold or consigned the skins for sale to the pastoral and stock and station companies. Dalgety and Company Limited, The Australian Mercantile Land and Finance Company Limited, The Co-operative Wool and Produce Company Limited, The New Zealand Loan and Mercantile Agency Company Limited, John Bridge and Company Limited, Younghusband, Row and Company, The Australian Estates and Mortgage and Agency Company, Harrison, Jones and Devlin Limited, J.C. Young and Company, McBurney, Wallis and Company, F.L. Barker and Company, the Pastoral Finance Association Limited and James Fay, McDonald and Company Limited were all heavily involved in the trade. The company with the heaviest involvement, however, was Winchcombe, Carson and Company, whose Sydney office placed letters in the farming and country newspapers on how to prepare rabbit skins and regularly sold around 1,000 tons a year. ${ }^{54}$

\section{Carcase Export}

By far the greatest impetus to the commercialisation of the rabbit was the export trade in frozen carcases. The export trade in frozen beef and mutton from Australasia to England commenced in the early 1880 s. $^{55}$ Rabbits were not part of this trade, despite the English having eaten rabbit meat for centuries. Joan Druett claimed in her 1983 study of introduced pests in New Zealand that "rabbit stew is so well founded in English recipe books that it could be rated a national dish." To satisfy this national craving Britain had imported up to 2 million rabbits a year from Ostend in Belgium from the 1830s and each year during the 1880s and 1890s imports of rabbit meat cost the nation between $£ 300,000$ and $£ 400,000$. $^{56}$

The Fresh Food and Ice Company in Sydney started exporting rabbits and hares to England in 1891. The initial shipment was small but the trade had grown to 7,000 rabbits and 10,000 hares in 1892. In this year the company received an order for 1 million rabbits but could not fill it as it was unable to obtain sufficient rabbits. The bulk of the rabbits were found in western NSW and most trappers worked for skins due to uncertainties of transporting carcases long distances over the rail network. Inland freezing works, at locations like Narrandera, only commenced freezing rabbits in $1895 .{ }^{57} \mathrm{~A} \mathrm{Mr}$ F. Newby, from Sydney, of whom little is known, exported 7,200 frozen rabbits to Messrs Chate and Harris, produce merchants in London, in mid1894. They arrived in "good condition" and were "sold privately." 58

Further private consignments were exported from NSW and Victoria and sold well in London. The success of these initiatives and the fact that state financed destruction was an expensive failure, prompted the governments of NSW and Victoria to support a number of trial shipments of frozen rabbit and hare carcases to England in 1894. The shipments consisted of 5,000 rabbits frozen in crates from NSW and over 20 tons of rabbits and hares hung, frozen in boxes from Victoria. The Victorian rabbits were larger by a pound a pair and presented better when unpacked; the hanging maintained their shape while the freezing in crates resulted in the NSW rabbits emerging "in all kinds of shapes". The Victorian rabbits sold for 1s each while the NSW shipment made $9 \mathrm{~d}$ each; a profit of $4.5 \mathrm{~d}$ and $1.5 \mathrm{~d}$ respectively a rabbit. ${ }^{59}$

The success of the trials, knowledge that the British market for rabbit meat was substantial, positive advice from the New Zealand Loan and Mercantile Agency about the future prospects of the trade and the need to generate employment and raise revenue to reduce government debt, the result of financial calamities during the previous three years of depression, convinced George Turner's government in Victoria to enter the trade through its Agricultural Department. The Victorian trade grew quickly. The Agricultural Department provided at minimum charges workers and facilities for grading, inspection, freezing and storage, and private firms, with contracts with British counterparts, purchased the rabbits from the trappers who had consigned them to Melbourne and exported them. By 1895, as more firms entered the trade and competition for rabbits became fierce, buyers were placed at country railway stations. Exports 
grew from 178,834 rabbits and hares in the first year to 5,678,224 in 1900 (these figures also include exports to NSW and Western Australia).$^{60}$

NSW did not follow Victoria's lead. A combination of a lack of inland freezer works, problems with the railroad network, and opposition from farming and grazing interests stymied attempts to start an export trade. However, opponents of the trade were fighting a losing battle. State financed destruction of rabbits continued to be costly. The Stock and Pasture Boards in NSW in 1896 spent $£ 5,800$ buying rabbit scalps, while Victoria, who had encouraged exports, was making "about $£ 200,000$ a year" from the trade. Delegates from the English Co-operative Societies visited Sydney in August 1896 and at receptions hosted by the Premier, George Reid, and the Governor, Viscount Hampton, and in meetings with the press, stated they could take all the rabbits and hares the colony could export. In 1897 the colony was in the third year of drought. Solutions were needed to lessen the environmental and economic damage wrought by the drought. The NSW Board of Exports decided that export of rabbits should commence, and James Stephenson, the Board's secretary, conducted a tour of inland towns and spoke in favour of exporting. The Minister of Agriculture, Mr Sydney Smith, "determined that the colony shall no longer lie under the stigma of neglecting to turn the rabbit and hare pest to useful account ... completed arrangements for inaugurating an export trade in these animals with London." The first shipment of five tons of hares left Sydney on 30 May $1897 .{ }^{61}$

Government sponsored exports of rabbits and hares proceeded slowly over the next three years. Despite Stephenson claiming during his country tour that half a million rabbits and hares a year were expected the Board of Exports exported only 250,000 over this period, a consequence of the Federation Drought and increased local demand. The majority were hares that were sourced from around Cooma, Bathurst, Goulburn and Bungendore, areas close to Sydney, while the rabbits came from Condobolin, Junee and "down the Hay [railway] line" in the west of the colony. The Board of Exports followed the example of the Victorian Department of Agriculture by providing to private exporters at minimal cost facilities and staff to receive, grade, pack and freeze the produce. Initially the trappers forwarded the rabbits by train to the exporters in Sydney, but buyers were located in rural centres from 1897. Limited freezer space and problems with the railways restricted exports until the early twentieth century. The rate of rejection, for example, was between 15 and 50 per cent due to slow trains or poor handling on the trains or by the trappers (rejects that were still fit for human consumption were sold in Sydney). ${ }^{62}$ In 1900, one Sydney firm received an order for 10,000 crates of rabbits $(240,000$ head) which was difficult to fill as freezer space was limited in Sydney. Privately owned companies erected freezer works around the state (at between $£ 3,000$ to $£ 6,000$ each) from 1902 or leased established ice works or dairy co-operative cool rooms in rural towns and froze the rabbits before railing them to depots in Sydney and Newcastle, or directly to the ship. This reduced the number of rejects as the rabbits were graded by government approved graders and frozen shortly after being trapped, ensured trappers were paid in cash immediately they handed over the rabbits and allowed trapping to be carried on for longer periods each year. The state railway started running special rabbit trains three days a week from 1902 and up to 50,000 rabbits arrived at Darling Harbour by train every day, the majority from stations in small towns and hamlets in the south west of the state. The advances in freezing and transport pushed exports from 570,736 rabbits in 1901 to 11,877,036 in $1906 .{ }^{63}$

Carcase exports remained strong during the twentieth century. A total of 522,134,000 carcases were exported from 1904 to 1947. NSW was the largest exporter of rabbits with Victoria, Queensland, South Australia and Tasmania providing smaller totals. Exports remained high during World War I, despite a shortage of shipping, the Great Depression and in the late 1940s. The lack of shipping during World War II stopped exports, but the loss of this market was offset 
by the rapid growth in local consumption. ${ }^{64}$ Exports slowed after the release of the myxomatosis virus by the Commonwealth Scientific and Industrial Research Organisation in 1951. The spread of the mosquito borne virus was helped along by diligent rabbit inspectors, aided and abetted by their employers, the Pastures Protection Boards, who inoculated rabbits with the virus and by farmers, who had read articles about how to spread the virus in farming newspapers, deliberately mixing infected rabbits with healthy ones. By mid-1953 it was estimated that four-fifths of all rabbits in south-east Australia had died. ${ }^{65}$ The only landholders not rejoicing about the release of the virus where those in far western NSW who had been rabbit farming on land unsuitable for sheep and cattle grazing for at least two decades and who, in the 1940 s, earned $£ 3,000$ to $£ 4,000$ a year from rabbit skins. ${ }^{66}$ Townships where the rabbit industry was the major industry continued to depend on the rabbits until the virus wiped them out in the surrounding countryside. Weethalle, a small town located due west of West Wyalong in western NSW, and Nyngan, for example, were still heavily dependent on the rabbit industry for their economic survival during 1952. After 1952, exporters sourced their rabbits from central Australia, an area too dry for the virus-carrying mosquito, and continued to export until the early 1970 s. $^{67}$

\section{Local Consumption}

Increased consumption of rabbit meat by Australians provided a stable market for rabbit carcases. Increased demand was not just from the larger urban areas, it included rural areas as well, and it was not just from the poorer classes, it included rich and poor alike. In 1896 each person in Australasia (the six colonies and New Zealand) consumed on average 256 pounds of beef, mutton and pork a year, the highest by a factor of two of any country in the world at that time. ${ }^{68}$ The consumption of rabbit meat did not feature in these calculations, but rabbits too were being consumed in large numbers.

Victorians were the largest consumers. The Melbourne Fish Market wholesaled around a million rabbits a year during 1880-1900, with a major spike in numbers to around 5 million rabbits a year in the early to mid-1890s. Other markets in Melbourne, and in Geelong and Ballarat, also wholesaled rabbits. By the end of the decade Melbournians were consuming over 10,000 rabbits a day. ${ }^{69}$ Rural towns and hamlets in the colony were usually supplied by local trappers. In Castlemaine in 1894, the Mount Alexander Common Trust hired Mr H.R. McNiece to clear the commons of rabbits, and paid him a subsidy of $£ 20$ and allowed him sell the trapped rabbits. In six months McNiece and his assistants had dispatched approximately 30,000 rabbits to markets in Melbourne as well as supplying all demand in the Castlemaine area. ${ }^{70}$

Although NSW was overrun by rabbits, the colony prior to 1894 imported rabbit carcases from Victoria and Tasmania for consumption in Sydney. ${ }^{71}$ Problems with not knowing if the rabbit from the interior of the colony had been poisoned and the inability of the colony's rail network to transport rabbit carcases from the western areas without the carcases putrefying during the journey prompted the imports. In February 1890, Robert Hudson shipped 50 frozen mutton carcases in insulated rail trucks from Narrandera to Sydney and they arrived in "excellent condition", despite a 30-hour journey. This experiment showed that rabbit carcases could be carried long distances by rail, which eventually opened up the rabbit infested country to the city market. The Australasian reported that on 28 April 1894 "over 6,500 rabbits left from the stations on the Hay line and Narrandera per train ... for Sydney" and further shipments followed in $1895 .{ }^{72}$ By 1895 Sydneysiders were reported to be consuming 20,000 rabbits a week, and by the end of the decade the figure had grown to 30,000 rabbits a week. ${ }^{73}$ By the late 1890 s rabbits were being sourced from all areas of the colony that was serviced by rail; upwards of 50,000 rabbits and hares a month were dispatched to Sydney from railway stations around Bathurst from 1897 to $1900 .{ }^{74}$ When demand outstripped supply as it did during 1899 in the depths of the Federation 
Drought, frozen rabbits were imported from Victoria; Joseph Cook, the Minister for Mines and Agriculture, reported in June that "considerable numbers ... [arrived] from Melbourne to meet the Sydney requirements." ${ }^{\prime 5}$

There are no figures for rates of consumption in rural NSW in the late nineteenth century. Reports in regional newspapers indicate that rabbits and hares were being sold locally from the early 1890s. ${ }^{76}$ The following reports from 1902, at the end of the Federation Drought, support the claim that rural people also consumed large quantities of rabbit meat. On 4 September 1902, the Bathurst Free Press and Mining Journal reported:

By far the greatest bulk of the rabbits trapped are sent to Sydney, but in addition to these, many hundreds are consumed locally. The butchers' meat is so scarce and dear that many householders are glad to procure the rabbit for food. As proof of this we might mention that a few days ago a dealer with 40 or 50 pairs was making his way to Sofala with the object of disposing of them. [When he] arrived at Wattle Flat [a small mining town north of Bathurst] the people became aware of what the man was offering for sale, and before he passed through that township his stock was exhausted. The man will doubtless be tempted to take another consignment at the earliest opportunity. ${ }^{77}$

This occurred daily in nearly every town in rural NSW. If country people could not find a trapper they increasingly bought rabbit from the town butcher but the price was a lot higher; in Tumut in August 1902 trappers were getting 5d for a pair of rabbits, while local butchers retailed the same rabbits for $12 \mathrm{~d}$ a pair and couldn't meet local demand. ${ }^{78}$

Rates of consumption remained high during the first half of the twentieth century. Sydneysiders consumed between 2 million to 6 million rabbits a year between 1910 and 1950, and up to 9 million were consumed in the state each year. ${ }^{79}$ The well-to-do also ate their fair share of rabbit, which belies the claim that rabbit was only fit for the poor. A Sydney rabbit-o was quoted in the Evening News (Sydney) in February 1914 as claiming that:

Potts Point likes its little bit of rabbit pie as much as Woolloomooloo, only they're too modest to own up to it ... This thing [his barrow] ain't no cop for toffs. It's too loud for her ladyship. Yer wants a basket with the rabbits tucked out of sight underneath a clean white cloth so as not to give the show away. Then you sneak up to the kitchen door and do a deal with me lady on the QT. ${ }^{80}$

The Adelaide fish and game market sold around 150,000 rabbits a year from 1900 to 1914, while the Melbourne fish market continued to wholesale up to a million rabbits a year up until the mid1920s. Sales spiked at the fish market between 1924 and 1930 to between two million and four million rabbits a year, possibly a consequence of the large industrial disputes in the shipping and timber industries. Numbers fell back to just under two million a year through the worst of the Great Depression, which also raises doubts about the argument that it was only the poor consuming rabbits. ${ }^{81}$ Residents of Brisbane and Adelaide consumed between 10,000 and 20,000 rabbits a week during the depression. ${ }^{82}$

The rate of consumption rose across the country during the late 1930s. The 27,000 residents in Launceston consumed between 80,000 and 100,000 rabbits each financial year, nearly double the figure achieved in 1928-29. Demand was so strong in Sydney in October 1936 that local authorities started "importing" an unknown number of carcases from Melbourne. During this year one large Sydney firm spent $£ 50,000$ buying rabbits in rural NSW to sell through 500 city and suburban shops. "Last spring," the firm, 
put away 20,000 pairs for the winter, and soon these in addition to the normal winter supplies, were consumed. It sells close on 1,500,000 rabbits to shops in the metropolitan area every year, and has 52 chilling depots in the country, all of which buy rabbits from trappers ... Demand for rabbits as a food in the city has increased so tremendously in the last 12 months that export figures have fallen as a result. The local price is so good it would be unprofitable for dealers to send the rabbits overseas. ${ }^{83}$

Rabbit meat was also scarce in country districts. The Wellington Times reported in September 1938 that "many people enjoyed eating a rabbit just as much as poultry. They could be had for the mere asking at one time, but now they cannot be bought." ${ }^{\prime 4}$ The Brisbane Worker claimed that NSW no longer had a rabbit problem. "The situation has been reversed; and, instead of 'the rabbits eating the settlers out', the danger now to be feared in NSW ... is that the humans will eat the rabbits out and then have to face a severer stage of starvation." 85 Adelaide, too, was dealing with a severe shortage of rabbits in butcher shops and for street hawkers. The Mail (Adelaide) reported that "more rabbits are being eaten now than ever before. Many people who had not previously eaten rabbits had them on their tables, and acquired a taste for rabbit, which has been retained." ${ }^{\prime 6}$

Rates of consumption spiked during World War II. The cessation of exports resulted in increased local supplies of rabbit meat while supplies of beef, mutton and lamb were rationed. Dunn estimates that Australians consumed 27 million rabbits a year during the 1940s and figures published in The Official Year Book of New South Wales, which showed that consumption of rabbit meat "per head per annum" increased from 9.7 pounds in 1938-39 to 16.1 pounds in 1948, support this claim. ${ }^{87}$

Following the release of the myxomatosis virus retailed rabbits could not be purchased anywhere in Australia for under $4 \mathrm{~s}$ a pair, which priced them out of most household budgets. ${ }^{88}$ Chicken replaced rabbit on household tables from 1960 onwards. Andrea Insch and Bradley Bowden estimate that during the last third of the twentieth century "chicken meat consumption per person rose from 4.4 to 32.9 kilograms, rivalling beef in totals of consumption." ${ }^{9}$

\section{The Trappers}

The majority of trappers were from the ranks of the casual labour force that lived and worked in rural areas. These workers usually found work on farms as additional labour during harvest, ploughing and shearing times at the beginning and end of each year. The winter months were normally a time of deprivation with little money and little or no work. Rabbiting also attracted building and metal industry tradesmen who were in secure employment, urban workers employed on low wages, shearers, policemen, miners, clerks, boot makers, blacksmiths, storekeepers, publicans, bank managers, urban professionals, seamen, undertakers, newspaper editors, railway workers, rabbit inspectors, printers and a former cabinet secretary. These men believed they would lead easier lives rabbiting and they could make more money than following their normal occupations. Whole families rabbited as a unit, which impacted on the children's attendance at school, and regularly earned up to $£ 10$ a week..$^{90}$

Continual waves of new workers entered the industry, with contemporaries likening each influx to the 1850s gold rush. In NSW in 1906:

there was a 'rush' something like that caused by a new discovery of gold. Quite a remarkable state of things is revealed by the report of the Labour Bureau. 'Practically all the unemployed in the country districts turned to rabbiting,' the report says. One of the country school inspectors reported: 'At the present juncture it is a difficult task to get children to do any home lessons [because they are rabbiting half the night]' ... In some 
parts of the state a wood famine existed, because carters would not waste their time in getting wood when they can earn such huge profits rabbit trapping ... In the Forbes district men could not be obtained for ploughing, fencing or wood-carting. They were all rabbiting. ${ }^{91}$

In mid-1906, the Sunday Times (Sydney) reported that it has been "inundated with inquiries from city labouring men, clerks and others for information as to how, when, and where to go trapping." On 3 June 1906 the paper published an interview with an employee of Curtis and Curtis, one of the bigger exporters of rabbits in NSW, who highlighted how trappers working around Wellington, Molong, Forbes, Gundagai and Crookwell were making $£ 3$ to $£ 4$ a week clear of all expenses, advised how men could enter the industry and offered the company's help to get men started. Each day the following week 100 to 150 men, mostly lowly paid workers employed in Sydney, called in at the company's offices at Darling Harbour hoping to take advantage of the offer, and after placing 60 men the company was forced to withdraw its offer. Hundreds of men also rushed the offices of the other six rabbit exporters in Sydney. ${ }^{92}$ Fifteen years later after prices for rabbit skins made 12s a pound thousands of trappers "flocked" to rural areas "as though it was gold rush". The same occurred in the late 1920s, the late 1930s and the 1940s when the prices for skins or carcases reached new highs. In 1941 when trappers were easily earning £ 40 a week, "the little town of Adaminaby, in the southern highlands, [became] rich overnight, and scenes like those of the gold rush days are being enacted on the main street. Rabbits, not gold, are the source of Adaminaby's new-found wealth" ${ }^{93}$ Five years later, when skin prices made $£ 1$ a pound rural areas were overrun with trappers and the rabbit inspector employed by the Tamworth Pastures Protection Board claimed "it is a wild rush similar to that for gold many years ago". ${ }^{4}$

The rabbit industry absorbed so many workers that there were severe labour shortages across all sectors and even when wages were increased there were few takers. Labour was unprocurable for land clearing, general farm work, wood carting, potato digging, road repair work, rock splitting (used in road construction) and harvest work; and there were shortages of rouseabouts, shearers, shed hands, chaff cutters, ploughmen, fencers and council workers. Several rabbit inspectors resigned and went rabbiting, while in 1919 the Tamworth Pastures Protection Board could not hire men to destroy rabbits because all available men were rabbiting for themselves and earning between $£ 10$ and $£ 30$ a week.${ }^{95}$ Labour shortages pushed up wages for many other occupations in the bush and made all work far more expensive. Rates for land clearing rose from between 10s and 20s an acre in 1907 to between 60s and 140s an acre in 1927. Rates demanded for fencing doubled in the same period. ${ }^{96}$ In 1907, Dr John Langley, the Anglican Bishop of Bendigo, suggested that unless districts in the diocese increased stipends paid to local clergy from $£ 100$ a year to $£ 300$ a year, they should be allowed to go rabbiting, where they could earn $£ 5$ a week. ${ }^{97}$ During 1917 wheat lumpers in NSW and Victoria told employers that they would go rabbiting unless daily rates were doubled to 20 s a day, and many walked off jobs to start rabbiting even after the higher rates were paid. ${ }^{98}$ Local councils could not attract tenders for road work even after increasing contract rates by 25 per cent and private building contactors could not hire tradesmen even after offering to double the award rate. ${ }^{99}$

Rabbiting became the economic mainstay in many rural towns. Geurie, a hamlet located south-east of Dubbo had "50 to 60 tenements" in 1906 and "over 150 trappers", while over 15 per cent of Tumut's residents were trappers in this year. ${ }^{100}$ When Billy Hughes, the federal ALP politician, visited Bathurst in early 1906 he was told by the largest shopkeeper in the town that 500 people, just over five per cent of residents, were earning their living by trapping and the town would be in a "very bad way" without the income from the trappers. ${ }^{101}$ The following list, while being far from exhaustive and only relating to small areas of NSW and Victoria, shows that at 
times during the twentieth century there were 650 trappers working around Murrumburrah, 300 to 400 at Young, 550 at Cowra, 500 at Bathurst, 250 each at Tumut and Galong, 120 at Narrabri, "over 500" on the Harden-Blayney railway line, 100 at Corowa, 80 to 100 at each of Dubbo, Queanbeyan, Bungendore and Yarrawonga, "hundreds" at Carcoar and "about 200" trappers around each of Forbes and Benalla. Smaller towns had up to 80 trappers, a high proportion of the local population. ${ }^{102}$ William Schey, Director of the NSW Labor Bureau, estimated in late 1906 that 16,000 people in the state were engaged in rabbit trapping and the industry was worth $£ 1$ million a year. Victoria, at this time, had 8,000 trappers and 24,000 people who were "dependent upon rabbits for their livelihood". ${ }^{103}$

High earnings were the prime attraction. While rabbiting was not for everyone, inexperienced trappers quickly earned more in a week than tradesmen would, and the more experienced regularly exceeded tradesmen's rates by multiples of between four and ten times. With regard the preserving sector in the nineteenth century, Farrer claims that at the Colac factory during its heyday in the 1870s, "nearly 200 men, including trappers and carters, had been employed, and about $£ 400$ per week paid out”. Trappers supplying the factory averaged between $£ 3$ and $£ 5$ a week. ${ }^{104}$ The Camperdown factory also paid out around $£ 300$ week in wages and payments to trappers. One carter to the Camperdown factory (he carted rabbits for trappers and charged them half-a-penny a pair) claimed in 1883 that he was making $£ 9$ a week (at half-apenny a pair this amounted to 8,640 rabbits a week), and he was quoted as stating in an interview with the local correspondent of The Argus:

that the introduction of rabbits into the colony is the finest thing that ever took place in the interests of the working man. Upon my venturing to suggest that the raising of wool and mutton would be more profitable where rabbits abound, and that it would add more to the wealth of the country if the grass consumed by the rabbits were used by sheep, the [carter] gravely shook his head and declared that he could not see it, as he knew well enough that he could not make $£ 9$ a week off the same ground if the owner ran sheep on it. ${ }^{105}$

During 1894-1895, the Euroa factory paid out $£ 500$ a week in wages to 70 employees and for rabbits supplied by over 200 trappers (at 3d a pair), the Hamilton factory in 1896 paid over 300 trappers $£ 12,177$ for $1,670,000$ rabbits at 3.5d a pair, the Mount Gambier Rabbit and Meat Preserving Company paid out $£ 11,175$ to trappers and $£ 5,718$ in wages between mid-1896 and October 1899, and the Port Fairy Preserving Company paid 155 trappers and 60 employees over $£ 15,000$ a year during the late 1890s. Trappers supplying these factories throughout the 1890 s, especially during the worst of the depression at the beginning of the decade, earned between $£ 3$ and $£ 9$ a week, up to three times the wages earned by tradesmen. The Millicent correspondent for the Adelaide based Chronicle, reported in April 1899 that the rabbit factory was working "day and night" and "some families are living solely on the results of their rabbit trapping operations". ${ }^{106}$

In the early twentieth century earnings by trappers in the carcase and skin trades exceeded these figures. During the first decade, when tradesmen in the cities were earning between $9 \mathrm{~s}$ and $11 \mathrm{~s}$ a day, labourers $7 \mathrm{~s}$ a day and farm labourers $16 \mathrm{~s}$ a week with board and lodging, the majority of rabbiters earned between $£ 2$ and $£ 10$ (40s to 200 s) a week, with a minority earning $£ 20$ (400s) a week or more. ${ }^{107}$ Figures taken from account books of rabbit purchasers in Young in April 1904 support these conclusions: 
One man in 9 days earned $£ 6 / 1 / 6$

One man in 19 days earned $£ 6 / 5 / 8$

One man in 6 days earned $£ 2 / 8 / 6$

One man in 14 days earned $£ 6 / 11 / 6$

Three men for 1 week earned $£ 10 / 13 / 3$

Three men in 4 days earned $£ 6 / 10 / 11$

Three men for 1 week earned $£ 9 / 18 / 0$

Three men for 4 days earned $£ 7 / 11 / 9$

One man for 6 days earned $£ 3 / 17 / 5$ (this man had not trapped till January in this year, and is now averaging 10 s per day)

Three men for 8 days earned $£ 13 / 15 / 3$

All these accounts are clear, there is nothing to deduct for cartage, as for every case they do their own carting. ${ }^{108}$

Further examples include a trapper in the Bathurst area who earned £ 29 over one week trapping for carcases in 1903; a trapper from Gilgandra who trapped 4,000 rabbits in a tank trap (a wire enclosed dam or waterhole with non-return funnels where thirsty rabbits could enter but not get out again) over four nights in January 1905 and earned just over $£ 41$ for his efforts; a Dubbo trapper in early 1905 who trapped 800 rabbits in one week using conventional spring traps and earned $£ 86 \mathrm{~s} 8 \mathrm{~d}$; a father and son from the Young district working a tank trap in 1906 who earned $£ 10$ pounds in four nights; one man in the Yass district who averaged $£ 5$ a week from 1902 to 1907, usually earning $£ 1$ a night over five nights; another trapper from Yass who trapped 1,800 rabbits over two days in 1906 and was paid $£ 215$ s $0 \mathrm{~d}$ for the haul at $5.5 \mathrm{~d}$ a pair (he either used a tank trap or drove the rabbits into a wire enclosure); "the Callaghan brothers [from Yass, in 1906, who were] forwarding an average of 2000 pairs weekly [ $£ 4516 \mathrm{~s} 8 \mathrm{~d}$ a week at $5.5 \mathrm{~d}$ a pair], and three brothers named Davis have made as much as £25 a week"; a trapper from Queanbeyan who delivered 798 pair of rabbits over one week in May 1907 and earned £ 18 5s 9d; and a Molong trapper who trapped 728.5 pairs of rabbits in six days in June 1908 and earned $£ 15$ 14s 3d. During April to September 1910, 200 trappers at Forbes were earning £ 1,600 a week, an average of $£ 8$ each, a figure that most experienced trappers who used steel traps earned at this time. ${ }^{109}$

The trappers knew they were on a good wicket. While a rabbiter's life was an isolated one and rabbiting was hard work generally undertaken in unpleasant conditions and not for the faint hearted or the squeamish, the majority of trappers considered it easier than other rural work. They chose when to work and how long to work each week. It was common for many to work a four or five day week at a time when nearly all other workers worked a six day week. It was possible to trap 12 months a year, which enabled rabbiters to remain "almost permanently in their own towns". ${ }^{110} \mathrm{~A}$ former shearer who had been rabbiting for six weeks and clearing $£ 4$ a week claimed in May 1906 that he would never return to shearing: "You can't go wrong for rabbits: they're everywhere. And they're as good as cash all the time". ${ }^{111}$ A representative from Curtis and Curtis claimed in 1906 that two men had been recommended to them and the company outfitted the men and sent them up country. Within two years the men had repaid all their debts and purchased wagons, tents and other equipment. As well, "they had kept their wives and families in comfort. They are prosperous, and can afford frequent holidays in town and pleasures and comforts not generally within the reach of the working man". ${ }^{112}$ A rabbiter at Narrabri, a former labourer for over 30 years and one who never had surplus cash, claimed in February 1909: 
This [rabbiting] is the best ticket I ever struck. I consider I have the life of a gentleman. I make from $£ 4$ to $£ 5$ [a week] all the year round. I am never short of a 'tenner,' and I went down to the Burns-Squires and Burns-Johnson fights [staged in Sydney on 24 August 1908 and 26 December 1908]. The rabbits paid for these trips. Talk about exterminating them! I say preserve them - they are a Godsend to many a poor man and his family. ${ }^{113}$

Payments remained high during economic downturns during the early 1920s and the Great Depression of the early 1930s. Towns with a freezer works or two continued to prosper through these bad times. During a 21-month period beginning in June 1932, the freezer works in Texas in southern Queensland exported over 4,000 tons of frozen carcases (approximately 3 million rabbits) and supplied the area around Texas and most of the rabbits consumed in Brisbane each week. The works paid between 300 and 400 trappers $£ 37,500$ for these rabbits at $6 \mathrm{~d}$ a pair. Similar figures were achieved by the Yelarbon works, located midway between Inglewood and Goondiwindi in Queensland. Over 150 trappers supplied the works with 5,000 rabbits a day, at $5 \mathrm{~d}$ a pair, and total daily earnings amounted to $£ 521 \mathrm{~s}$ 8d. ${ }^{114}$ Balranald and Mildura, located in south-western NSW, both had two freezers operating throughout the depression years and combined they spent approximately $£ 20,000$ a year to purchase over 2 million rabbits. The financial benefits were felt in the two townships and throughout their hinterlands; "Some 37 rabbiters working along the north edge of the Millewa are sending about 9,000 pairs a week to the Mildura factory [and making $£ 9$ a week each]". ${ }^{115}$ Rainbow, located in the northwestern Victorian Mallee region, had a population of 916 of whom 75 were trappers supplying the local chilling rooms. The trappers supplied over 4,000 pairs a week and earned between $£ 4$ and $£ 8$ a week each, significant earnings in a small town. ${ }^{116}$ Identical economic benefits from freezing works or chilling rooms can be listed for many other towns. Monthly payments at Ararat (Vic) amounted to £ 1,000; Tottenham (NSW) £ 1,200; Merriwa (NSW) £ 750; Horsham (Vic.), £ 1,200; Tamworth (NSW); £ 2,000, Ouyen (Vic.), £ 1,000; Swan Hill (Vic.), £ 500; Gulgong (NSW) £ 800; and Renmark (SA), £ 500. ${ }^{117}$

Earnings reached astronomical levels during the 1940s and early 1950s. Increased prices for both carcases and skins pushed average earnings to between $£ 20$ and $£ 50$ a week, with some trappers earning up to $£ 100$ a week. Carcases were worth between $20 \mathrm{~d}$ and $28 \mathrm{~d}$ a pair at most freezer works due to increased demand for meat and a consequence of the high prices for skins. At $20 \mathrm{~d}$ a pair 50 pairs a night, a moderate catch, returned $£ 43$ s 4 d. Prices in Kyneton (Victoria) in 1941 were $22 \mathrm{~d}$ a pair, which caused townspeople and farmers to forsake "their regular callings in order to trap rabbits". ${ }^{118}$ In what was a common experience around Nyngan in the late 1940s and early 1950s, three trappers in early January 1949 caught 25,000 rabbits in a tank trap in one week and sold them to the freezer works at Hermidale, located on the Barrier Highway to the east of Nyngan, for $£ 1,19718 \mathrm{~s} 4 \mathrm{~d}$ at $23 \mathrm{~d}$ a pair. ${ }^{119}$ Skins also brought high returns. During 1941, 80 trappers at Adaminaby (NSW) easily earned $£ 40$ a week each and children who rabbited on weekends made $£ 1$ without much effort. Two years later a trapper from Inverell sold skins worth $£ 93$, the result of 11 nights trapping, and three teenagers from Bukkulla, near Inverell, made £ 142 from four weeks of trapping. ${ }^{120}$ In 1944, trappers in the Singleton district consistently earned an average of $£ 7$ a night or around $£ 30$ a week. ${ }^{121}$ One of the best earners in Australia was 32year-old Frank Hogno. Hogno trapped around Tamworth for five months a year and averaged $£$ 100 a week. For the remaining seven months of the year he stayed with his wife and two girls in Kirribilli in Sydney and lived the life of a gentleman. Despite not working for most of each year he had savings of over $£ 5,000$ by 1946 . He started this routine in 1942 and expected to continue it for as long as he could. ${ }^{122}$ 
The rabbit industry had a profound effect on the lives of thousands of rural Australians. Over 100 years, trappers were able to earn considerably more money each week than any other manual occupation. The difference in pay rates was measured in multiples of between two and ten times. The major beneficiaries were unskilled and semi-skilled workers who had been part of the reserve army of labour in rural areas when farming was relatively labour intensive and required large numbers of workers at peak times of the year. They were joined by thousands of other workers from a host of different occupations. Apart from the high earnings rabbiting allowed workers to reside in one location all year and to enjoy the benefits that higher incomes brought, especially holidays, rest, trips to the city, acquiring possessions and bank savings, and meeting the daily necessities of life. Commercialisation of the rabbit commenced in the early nineteenth century and it powered ahead after 1880 . The preserving industry and skin trade were dominant in the late nineteenth century. While the skin trade remained dominant until the 1950s, the frozen carcase trade became a major feature from the late 1890s until the 1970s. Increased consumption of rabbit meat by Australians also bolstered the trade. Rabbit meat was consumed by rich and poor alike in cities and towns across Australia. Claims that rabbit meat was only a poor person's food or that rural people didn't eat rabbit meat belie material reality. The industry was the economic mainstay in many rural towns, villages and hamlets. Local businesses became dependent on the trade, which enabled them to carry sheep, wheat and dairy farmers over the frequent bad times, some of which were the result of the competition for feed with the rabbit. Depression, drought and war had little impact on the industry or the earnings enjoyed by the trappers. Like gold the rabbit industry was a depression beater, and for 100 years it was a boon for the working class.

\section{Endnotes}

\footnotetext{
* This paper has been subject to double blind refereeing.

${ }^{1}$ The Mercury (Hobart), 9 July 1929, 11; The Official Year Book of New South Wales (YBNSW), 1904-31, passim; Victorian Year Book (VYB), 1903-30, passim.

${ }^{2}$ Brian Coman, Tooth \& Nail: The Story of the Rabbit in Australia (Melbourne: Text Publishing, 1999), 146$170,236-237$.

${ }^{3}$ James Matthams, The Rabbit Pest in Australia (Melbourne: The Specialty Press, 1921); David Stead, The Rabbit Menace in New South Wales (Sydney: Government Printer, 1928); Eric Rolls, They All Ran Wild (Sydney: Angus and Robertson, 1977); Rae Pennycuick, Keeping Rabbits Out: Darling Downs-Moreton Rabbit Board (Warwick: Darling Downs-Moreton Rabbit Board, 1995); Stephen Dando-Collins, Pasteur's Gambit: Louis Pasteur, The Australasian Rabbit Plague and a Ten Million Dollar Prize (North Sydney: Vintage Books, 2008).

${ }^{4}$ L.J. Dunn, The Rabbit Industry: An Economic Survey 1904-1947 (Canberra: Bureau of Agricultural Economics, 1948).

${ }^{5}$ Catherine Watson, The Rabbit King (Niddrie: Boniyong Pastoral Company, 1996).

${ }^{6}$ G.B. Eggleton, Last of the Lantern Swingers (Mildura: Parraweena Publishing, 1982).

${ }^{7}$ Jenny Quealy, ed., Great Australian Rabbit Stories (Sydney: ABC Books, 2010).

${ }^{8}$ Simon Ville, The Rural Entrepreneurs: A History of the Stock and Station Agent Industry in Australia and New Zealand (Melbourne: Cambridge University Press, 2000); J.D. Bailey, A Hundred Years of Pastoral Banking: A History of the Australian Mercantile Land and Finance Company 1863-1963 (Oxford: Clarendon Press, 1966); Richard Waterhouse, The Vision Splendid: A Social and Cultural History of Australia (Fremantle: Curtin University Books, 2005).

${ }^{9}$ C.B. Schedvin, "Rabbits and Industrial Development: Lysaght Brothers \& Co. Pty. Ltd., 1884-1929," Australian Economic History Review (AEHR) 7, no. 1 (March 1967): 27-55.

${ }^{10}$ K.H. Farrer, A Settlement Amply Supplied: Food Technology in Nineteenth Century Australia (Melbourne: Melbourne University Press (MUP), 1980).
} 
${ }^{11}$ H.M. Boot, "Debts, drought and foreclosure: wool-producers in Queensland and New South Wales, 18701905," AEHR 28, no. 2 (September 1988): 33-52; Alan Barnard, ed., The Simple Fleece: Studies in the Australian Wool Industry (Melbourne: MUP, 1962); Kosmas Tsokas, Markets, Money \& Empire: The Political Economy of the Australian Wool Industry (Melbourne: MUP, 1990).

${ }^{12}$ N.L. Howlett, “The Bear You Couldn't Buy: Shooting Koalas in Queensland: 1927," Bowyang 1, no. 2 (Sept-Oct 1979): 9-24.

${ }^{13}$ Colonial Times and Tasmanian Advertiser, 22 May 1827; The Mercury (Hobart), 18 November 1948, 3; Jan Kociumbas, The Oxford History of Australia, Vol. 2, 1770-1860 (Melbourne: Oxford University Press (OUP), 1992), 249.

${ }^{14}$ Rolls, They All Ran Wild, 19-20; A. Rand, "Bell, John (1790-1841)," Australian Dictionary of Biography (ADB), Vol. 1 (Melbourne: MUP, 1966), 80; J. Ann Hone, “Amess, Samuel (1826-1898),"ADB, Vol. 3 (Melbourne: MUP, 1969), 29; and "Black, George (1813-1902)," ADB, Vol. 3 (Melbourne: MUP, 1969), 168; G.C. Fendley, "McCoy, Sir Frederick (1817-1899)," ADB, Vol. 5 (Melbourne: MUP, 1974), 134-136.

${ }^{15}$ Henry Holt, An Energetic Colonist: A Biographical Account of the Activities of the Late Hon. Thomas Holt, MLC (Melbourne: The Hawthorn Press, 1972), 122.

${ }^{16}$ Rolls, They All Ran Wild, 21, 32.

${ }^{17}$ Ibid., 32.

${ }^{18} \mathrm{Ibid} ., 38-60$.

${ }^{19}$ Windsor and Richmond Gazette, 21 March 1891, 2; The Cumberland Argus and Fruitgrowers Advocate (Parramatta), 28 March 1891, 6; Bathurst Free Press and Mining Journal, 13 March 1895, 2; Paul de Serville, Tubbo: The Great Peter's Run (Melbourne: OUP, 1982), 136.

${ }^{20}$ Bathurst Free Press and Mining Journal, 16 February 1895, 2.

${ }^{21}$ The Bacchus Marsh Express, 25 April 1874, 3; Sydney Morning Herald (SMH), 1843-67, passim; South Australian Register, 1845, passim.

${ }^{22}$ South Australian Register (Adelaide), 27 September 1875, 7.

${ }^{23}$ Farrer, A Settlement Amply Supplied, 115.

${ }^{24}$ The Hobart Town Courier, 8 January 1836, 3; SMH, 6 October 1873, 7; Launceston Examiner, 1878-83, passim; The Mercury (Hobart), 1873-83, passim; and 18 November 1948, 3.

${ }^{25}$ The Bacchus Marsh Express, 8 January 1881, 4.

${ }^{26}$ Kerang Times and Swan Hill Gazette, 8 May 1885, 4; VYB, 1880-81, 70; The Mercury (Hobart), 20 January 1873, 2 and 3 August 1875, 3; Irene Schaffer, “Bidencope, Joseph (1837-1915)," ADB, Supplement (Melbourne: MUP, 2005), 30-31.

${ }^{27}$ The Bacchus Marsh Express, 11 February 1882, 3 and 18 March 1882, 4.

${ }^{28}$ YBNSW, 1904-05, 284-285; VYB, 1903, 410; Matthams, The Rabbit Pest, 16-31.

${ }^{29}$ Farrer, A Settlement Amply Supplied, 116-117; The Argus (Melbourne), 23 January 1882, 7; Camperdown Chronicle, 11 April 1885, 2.

${ }^{30}$ Camperdown Chronicle, 25 July 1891, 2.

${ }^{31}$ Portland Guardian, 14 March 1892, 3; Euroa Advertiser, 12 April 1895, 3; and 15 May 1896, 2; Warragul Guardian, 17 April 1896, 3; The Australasian (Melbourne), 5 August 1899, 7; The Argus (Melbourne), 20 August 1900, 7.

${ }^{32}$ Alexandra, and Yea Standard, Gobur, Thornton and Archeron Express, 20 May 1892, 2; Euroa Advertiser, 7 July 1893, 2; The Argus (Melbourne), 14 August 1893, 3; 26 July 1897, 6 and 20 August 1900, 7; Camperdown Chronicle, 14 January 1897, 3; The Colac Herald, 13 August 1897, 4 and 22 November 1898, 4; The Australasian (Melbourne), 14 August 1897, 7 and 5 August 1899, 7; Portland Guardian, 29 May 1899, 3.

${ }^{33}$ Euroa Advertiser, 16 April 1897, 3.

${ }^{34}$ South Australian Register (Adelaide), 3 September 1877, 6 and 6 October 1877, 4; Farrer, A Settlement Amply Supplied, 124-125.

${ }^{35}$ Chronicle (Adelaide), 1897-1920, passim; Border Watch (Mount Gambier), 1897-1920, passim.

${ }^{36}$ Petersburg Times (South Australia), 11 September 1896, 4; Chronicle (Adelaide), 25 March 1899, 28 and 22 April 1899, 13; Border Watch (Mount Gambier), 5 February 1898, 3.

${ }^{37}$ Border Watch (Mount Gambier), 7 October 1896, 3; Chronicle (Adelaide), 30 December 1899, 28. 
${ }^{38}$ Evening News (Sydney), 13 February 1893, 5; 4 March 1896, 6; and 22 July 1896, 3; Western Herald (Bourke), 26 January 1895, 2; Riverina Recorder (Balranald), 22 April 1896, 2 and 22 July 1896, 2; The Riverine Grazier (Hay), December 1896-February 1902, passim; SMH, 28 May 1897, 5.

${ }^{39}$ For the Chicago meat scandal, see: Chronicle (Adelaide), 8 December 1906, 6 and 8 June 1907, 13; Upton Sinclair, The Jungle (New York: Penguin Books, 1986 [first published in America by Doubleday, Page, 1906]); Doris Kearns Goodwin, The Bully Pulpit: Theodore Roosevelt. William Howard Taft, and the Golden Age of Journalism (New York: Simon \& Schuster, 2013) 459-464. For military orders see: Bathurst Free Press and Mining Journal, 17 February 1904, 2; Albury Banner and Wodonga Express, 11 March 1904, 22; SMH, 12 June 1908, 9 and 21 January 1910, 9; Manchester Courier and Lancashire General Advertiser (UK), 10 July 1908, 14. For production see: Border Watch (Mount Gambier), 1910-1920, passim; Chronicle (Adelaide), 1910-1920, passim; The Bacchus Marsh Express, 18 June 1910, 2; The Farmer and Settler (Sydney), 8 August 1911, 6 and 24 September 1918, 6; VYB, 1910-1920, passim; Official Year Book of the Commonwealth of Australia, 1920, 533.

${ }^{40}$ Western Daily Press (UK), 16 December 1922, 5.

${ }^{41}$ Border Watch (Mount Gambier), 30 May 1944, 4.

${ }^{42}$ For Victoria, see: Nottingham Evening Post (UK), 12 February 1894, 4; Euroa Advertiser, 16 April 1897, 3; The Broadford Courier and Ready Creek Times, 17 April 1903, 2; Riverine Herald (Echuca), 11 January 1896, 4; For Tasmania, see: Oakleigh Leader (North Brighton), 15 October 1892, 2; The Mercury (Hobart), 21 October 1896, 2; Launceston Examiner, 2 September 1897, 4; For South Australia, see: The Register (Adelaide), 2 October 1905, 6.

${ }^{43}$ Australian Town and Country Journal, 1890-96, passim.

${ }^{44}$ The Advertiser (Adelaide), 13 February 1942, 11 (republished from 13 February 1892).

${ }^{45}$ Australian Town and Country Journal, 25 March 1893, 43.

${ }^{46}$ The Argus (Melbourne), 23 June 1893, 6; The Colac Herald, 14 June 1895, 3.

${ }^{47}$ The Horsham Times, 19 May 1899, 3.

${ }^{48}$ Dunn, The Rabbit Industry; SMH, 28 January 1920, 9; 16 September, 1929, 13; and 26 February 1947, 3; The Register (Adelaide), 12 June 1923, 7; West Gippsland Gazette, 7 August 1928, 2; Warwick Eather and Drew Cottle, "'A Curse to the Landowner, but a Blessing to the Poor Man': A History of the Rabbit Industry", unpublished paper.

${ }^{49}$ The Bacchus Marsh Express, 17 June 1882, 2 and 26 May 1883, 3.

${ }^{50}$ For Daniels, see: Goulburn Herald, 9 February 1902, 4; The Age (Queanbeyan), 5 January 1906, 2 and 24 September 1909, 2; Queanbeyan Age, 21 October 1913, 2. For Bimbi, see: The Grenfell Record and Lachlan District Advertiser, 24 February 1906, 10. For Boomey, see: Wellington Times, 21 June 1906, 3.

${ }^{51}$ Rolls, They All Ran Wild, 74-75.

${ }^{52}$ SMH, 15 September 1904, 3; 21 September 1907, 9; 19 September 1919, 5; and 9 April 1936, 16.

${ }^{53}$ The Peak Hill Express, 21 July 1905, 5; Molong Express, 11 August 1905, 11.

${ }^{54}$ Eather and Cottle, "A Curse to the Landowner," 3.

${ }^{55}$ Rolls, They All Ran Wild, 76.

${ }^{56}$ South Australian Register (Adelaide), 8 May 1847, 4; London Standard (UK), 12 October 1852, 1; Sussex Advertiser (UK), 30 March 1864, 1; The Riverine Grazier (Hay), 19 June 1896, 4; Euroa Advertiser, 16 April 1897, 3; Joan Druett, Exotic Intruders (Auckland: Heinemann, 1983), 151; Mark Bailey, "The Rabbit and the Medieval East Anglian Economy", The Agricultural History Review 36, no. 1 (1988): 1-20 (we would like to thank Humphrey McQueen for this reference).

${ }^{57}$ Australian Town and Country Journal, 1 September 1894, 45 and 3 November 1894, 45; Warragul Guardian and West Gippsland Advertiser, 19 October 1894, 2; Goulburn Herald, 5 December 1894, 4; The Argus (Melbourne), 8 April 1895, 5; The Australasian, 13 April 1895, 7.

${ }^{58}$ Australian Town and Country Journal, 4 August 1894, 41; Evening News (Sydney), 11 September 1894, 4.

${ }^{59}$ Australian Town and Country Journal, 1 September 1894, 45 and 3 November 1894, 45; Goulburn Herald, 5 December 1894, 4; The Argus (Melbourne), 8 April 1895, 5; The Australasian, 13 April 1895, 7.

${ }^{60}$ The Broadford Courier and Reedy Creek Times, 8 May 1896, 2 and 17 April 1903, 2; SMH, 31 May 1904, 4; The Argus (Melbourne), 8 April 1895, 5. For Western Australia and NSW, see: The Inquirer and Commercial News (Perth), 23 October 1896, 11; Goulburn Evening Penny Post, 24 June 1899, 4. 
${ }^{61}$ SMH, 8 August 1895, 6 and 2 June 1897, 4; Goulburn Evening Penny Post, 1 May 1897, 2 and 5 June 1897, 5; Sydney Wool and Stock Journal, 9 June 1899, 10.

${ }^{62}$ Goulburn Evening Penny Post, 3 August 1897, 4 and 1 October 1898, 4; The Braidwood Dispatch and Mining Journal, 4 August 1897, 2; Dubbo Liberal and Macquarie Advocate, 19 March 1898, 3; Australian Town and Country Journal, 15 April 1899, 27; Evening News (Sydney), 12 August 1899, 4; Wellington Times (NSW), 4 October 1900.

${ }^{63}$ SMH, 20 July 1904, 6; YBNSW, 1925-26, 561; Eather and Cottle, "A Curse to the Landowner," 27-28, fn. 145 .

${ }^{64}$ Dunn, The Rabbit Industry, Appendix A.

${ }^{65}$ YBNSW, 1961, 908; Narromine News and Trangie Advocate, 16 February 1951, 6; Daily Advertiser (Wagga Wagga), 24 February 1951, 4; The Lyndhurst Shire Chronicle, 7 March 1951, 5; The Muswellbrook Chronicle, 22 March 1951, 3; Newcastle Morning Herald, 22 March 1951, 1; The Land (Sydney), 16 November 1951, 1.

${ }^{66}$ Barrier Miner (Broken Hill), 14 March 1951, 5.

${ }^{67}$ The Narromine News and Trangie Advocate, 13 April 1951, 1; Western Herald (Bourke), 20 April 1951, 12; The Farmer and Settler (Sydney), 15 February 1952, 6.

${ }^{68}$ T.A. Coghlan, A Statistical Account of the Seven Colonies of Australasia, 1895-6 (Sydney: Government Printer, 1896) 104.

${ }^{69}$ The Argus (Melbourne), 1880-1900, passim.

70 The Mercury (Hobart), "News From Melbourne”, 25 May 1894, 2.

${ }^{71}$ SMH, 30 June 1888, 10 and 24 June 1893, 11.

${ }^{72}$ The Australasian (Melbourne), 5 May 1894, 761.

${ }^{73}$ Evening News (Sydney), 27 August 1895, 3.

${ }^{74}$ Bathurst Free Press and Mining Journal, 5 June 1899, 3 and 15 June 1899, 2.

${ }^{75}$ Goulburn Evening Penny Post, 24 June 1899, 4.

${ }^{76}$ Goulburn Evening Penny Post, 2 August 1894, 2.

${ }_{77}$ Bathurst Free Press and Mining Journal, 4 September 1902, 2.

${ }^{78}$ The Sydney Stock and Station Journal, 26 August 1902, 4; Adelong and Tumut Express and Tumbarumba Post, 19 September 1902, 2.

79 YBNSW, 1925-26, 561; Recorder (Port Pirie), 28 January 1920, 3; The Mercury (Hobart), 9 July 1929, 11; Dunn, The Rabbit Industry, 29.

${ }^{80}$ Evening News (Sydney), 11 February 1914, 10.

${ }^{81}$ VYB, 1919-40, passim; The Advertiser (Adelaide), 1900-14, passim; The Register (Adelaide), 1907-13, passim.

${ }^{82}$ The Mail (Adelaide), 23 January 1915, 9; The Courier Mail, 11 November 1941, 3.

${ }^{83}$ The Carcoar Chronicle, 30 October 1936, 1; Examiner (Launceston), 1928-1938, passim.

${ }^{84}$ Wellington Times, 19 September 1938, 2.

${ }^{85}$ Worker (Brisbane), 10 November 1936, 10.

${ }^{86}$ The Mail (Adelaide), 24 October 1936, 9.

${ }^{87}$ Dunn, The Rabbit Industry, 29, Appendix A; YBNSW, 1948-49, 286.

88 The Portland Guardian, 28 July 1952, 2; The Argus (Melbourne), 29 April 1955, 3.

${ }^{89}$ Andrea Insch and Bradley Bowden, “The 'healthy alternative'? Transformation of Production and Work Organisation in the Australian Chicken Meat Sector", in Transforming Labour: Work, Workers, Struggle and Change (Proceedings of the Eighth National Labour History Conference, Griffith University, Brisbane, 3-5 October 2003), ed. Bradley Bowden and John Kellett, 170.

${ }^{90}$ Eather and Cottle, "A Curse to the Landowner," 1-58.

${ }^{91}$ The Argus (Melbourne), 20 February 1907, 8.

92 Sunday Times (Sydney), 3 June 1906, 5; 10 June 1906, 5; 24 June 1906, 2.

${ }^{93}$ The Advertiser (Adelaide), 23 July 1921, 9; Advocate (Burnie), 23 May 1941, 2.

${ }^{94}$ Western Mail (Perth), 19 December 1946, 52.

${ }^{95}$ SMH, 1900-50, passim, The Argus (Melbourne), 1900-50, passim; The Mercury (Hobart), passim;

Australian Town and Country Journal, 1906-07, passim; The Farmer and Settler, 1906-40, passim; The Peak Hill Express, 15 June 1906, 18 and 24 May 1907, 17; The Sydney Stock and Station Journal, 10 July 1906, 4; 
The Age (Queanbeyan), 1 March 1907, 2; Wellington Times, 16 May 1907, 2; Portland Guardian, 6 June $1919,3$.

${ }^{96}$ New South Wales Legislative Council, Hansard, 11 March 1927, 2270-2273; SMH, 8 March 1921, 8.

${ }^{97}$ Bairnsdale Advertiser and Tambo and Omeo Chronicle, 10 September 1907, 4.

${ }^{98}$ Daily Advertiser (Wagga Wagga), 17-30 May 1917, passim; The Bathurst Times, 21 May 1917, 1; Bendigo Advertiser, 21 May 1917, 4; SMH 22 May 1917, 5.

${ }_{99}$ The Peak Hill Express, 18 May 1906, 17 and 15 June 1906, 18; Evening News (Sydney), 22 October 1908, 3; The Register (Adelaide), 14 May 1910, 14; West Gippsland Gazette (Warragul), 24 May 1910, 7.

${ }^{100}$ SMH, 12 May 1906, 7; The Gundagai Times and Tumut, Adelong and Murrumbidgee District Advertiser, 5 May 1907, 2.

${ }^{101}$ Commonwealth Parliament of Australia, House of Representatives Hansard On-line, W.M. Hughes, 14 June 1906, accessed 26 November 2011, hansard80/hansardr80/1906-06-14/0073.

${ }^{102}$ Eather and Cottle, "A Curse to the Landowner," 30.

${ }^{103}$ Barrier Miner (Broken Hill), 12 October 1906, 2; The Sydney Wool and Stock Journal, 17 April 1903, 7;

The Farmer and Settler (Sydney), 16 May 1906, 4.

${ }^{104}$ Farrer, A Settlement Amply Supplied, 117.

${ }^{105}$ The Argus (Melbourne), 25 May 1883, 3.

${ }^{106}$ Chronicle (Adelaide), 22 April 1899, 13; Eather and Cottle, “A Curse to the Landowner," 17-18.

${ }^{107}$ Eather and Cottle, "A Curse to the Landowner," 1-58.

108 The Age (Queanbeyan), 29 April 1904, 2.

${ }^{109}$ Eather and Cottle, "A Curse to the Landowner," 30.

${ }^{110}$ Sunday Times (Sydney), 3 June 1906, 5; SMH, 16 March 1910, 9 and 18 May 1910, 6; The Sydney Stock and Station Journal, 18 March 1910, 6.

${ }^{111}$ Evening News (Sydney), 25 May 1906, 4.

${ }_{112}$ Sunday Times (Sydney), 3 June 1906, 5.

${ }^{113}$ Evening News (Sydney), 26 February 1909, 3

${ }^{114}$ The Courier Mail, 5 March 1934, 5.

${ }^{115}$ Murray Pioneer and Australian River Record (Renmark), 12 June 1931, 4 and 19 June 1931, 5; The Argus (Melbourne), 23 February 1932, 9; The Burrowa News, 5 June 1931, 4.

${ }^{116}$ The Argus (Melbourne), 25 June 1932, 10; The Horsham Times, 22 July 1932, 8.

${ }^{117}$ Eather and Cottle, "A Curse to the Landowner," 53.

${ }^{118}$ The Land (Sydney), 30 May 1941, 3.

${ }^{119}$ The Muswellbrook Chronicle, 28 January 1949, 8.

${ }^{120}$ The Land (Sydney), 21 May 1943, 10 and 13 August 1943, 9.

${ }^{121}$ Singleton Argus, 16 June 1944, 2 and 23 June 1944, 3.

122 The Argus (Melbourne), 31 May 1946, 3; The Mercury (Hobart), 31 May 1946, 2. 
Nic Maclellan, "Grappling with the Bomb: Opposition to Pacific nuclear testing in the 1950s", Proceedings of the 14th Biennial Labour History Conference, eds, Phillip Deery and Julie Kimber (Melbourne: Australian Society for the Study of Labour History, 2015), 21-38. ISBN: 978-0-9803883-3-6.

\title{
Grappling with the Bomb: Opposition to Pacific nuclear testing in the 1950s
}

\author{
Nic Maclellan
}

In the fifty years from 1946-1996, the United States, France and the United Kingdom conducted over 315 nuclear tests in the Pacific islands. Starting in the 1940s, there was popular opposition to these testing programs across Australia, New Zealand and the Pacific Islands, led by trade unions, churches and indigenous organisations. The author, who was a member of the Nuclear Free and Independent Pacific movement (NFIP) and served in its regional secretariat in Fiji, will discuss the impacts of nuclear testing on the civilian and military personnel who staffed the test sites over fifty years, as well as neighbouring island communities. Using British nuclear testing on Kiritimati (Christmas Island) as a case study, the article will detail ongoing efforts by nuclear survivors to seek recognition and compensation for the health an environmental impacts of testing.

From the beginning of the nuclear age, the United States, Britain and France sought "empty" spaces to conduct their Cold War programs of nuclear testing. For fifty years between 1946 and 1996, the deserts of Australia and the islands of the central and south Pacific were used to conduct over 315 atmospheric and underground tests at ten different sites. From 1946 to 1958, the United States conducted 67 atomic and hydrogen bomb tests at Bikini and Enewetak atolls in the Marshall Islands. In the 1960s, there were 25 further US tests at Christmas (Kiritimati) Island for Operation Dominic and nine more at Johnston (Kalama) Atoll. ${ }^{1}$ Britain tested nuclear weapons in Oceania between 1952-58, with 12 tests at the Monte Bello Islands, Maralinga and Emu Field in Australia (1952-57). ${ }^{2}$ These were followed by nine hydrogen bomb tests at Christmas (Kiritimati) Island and Malden Island in the central Pacific (1957-58). ${ }^{3}$ After conducting 17 nuclear tests in Algeria at Reganne and In Eker between 1960-66, France moved its test sites to the South Pacific. From July 1966 to January 1996, France conducted 193 atmospheric and underground tests at Moruroa and Fangataufa atolls in French Polynesia. ${ }^{4}$

These desert and ocean sites were chosen because they seemed to be vast empty spaces. But the nuclear powers showed little concern for the health and well being of nearby indigenous communities and those civilian and military personnel who staffed the test sites. Many people in the Pacific welcomed the development of nuclear installations across the region, for the economic and employment opportunities created by an influx of military personnel. Political leaders, from Sir Robert Menzies in Australia to Gaston Flosse in French Polynesia, enhanced their political careers through their fawning loyalty to Empire. But significant minorities in countries across the region resisted the nuclear era and continue to campaign for compensation for the health and environmental consequences of more than 300 nuclear tests. Throughout the decades of testing in the Pacific islands, there was widespread popular resistance. Alliances of trade unions, churches, women's organisations and customary leaders in the islands campaigned for an end to nuclear testing and the abolition of nuclear weapons. Support for nuclear disarmament in Pacific Rim countries like Australia, New Zealand, Japan and the United States is well documented, but there is less recognition of the long-standing resistance by Pacific Island peoples to the nuclear weapons programs. $^{5}$

Following its founding conference in Fiji in 1975, the Nuclear Free and Independent Pacific (NFIP) movement was a driving force in this campaign, linking the issues of 
environmental damage to indigenous campaigns for self-determination and political independence. The signing of the Rarotonga treaty for a South Pacific Nuclear Free Zone (SPNFZ) on Hiroshima Day 1985 and the end of French nuclear testing in 1996 were important milestones. However, before the revival of Pacific disarmament campaigning in the 1970s and 1980s, there were sporadic protests against nuclear testing in earlier decades across the islands region.

This paper starts with some examples of these islander protests during the 1950s. The paper then details responses to the UK nuclear testing program in the British Gilbert and Ellice Islands Colony, codenamed Grapple, in $1957-8 .{ }^{6}$ Most people recognise the names Maralinga, Bikini and Moruroa as nuclear test sites, but Kiritimati and Malden Island are less well known. For this reason, the paper presents the history of the Grapple tests through a patchwork of letters, archival records and oral testimony for four people: pacifist Harold Steele, businessman James Burns, Gilbertese woman Sui Benan Kiritome, and Fijian sailor Paul Ah Poy. These stories reflect the growing number of personal testimonies about nuclear testing in the Pacific. In recent publications, workers, military personnel and indigenous peoples have told their own history in their own words: women from Yankunytjatjara and Pitjantjatjara communities in South Australia; the Gilbertese workers and Fijian soldiers and sailors who witnessed Britain's H-bomb tests; and the Maohi labourers who staffed the nuclear test sites of French Polynesia for 30 years. ${ }^{7}$

\section{Opposition to nuclear testing across Oceania}

One of the earliest indigenous anti-nuclear protests was in French Polynesia in 1950, when the Tahitian leader Pouvanaa a Oopa - a military veteran in both world wars - collected signatures for the March 1950 Stockholm Peace Appeal. According to Marie-Thérèse Danielsson:

Pouvanaa a Oopa, understanding the importance of this document, decided to take the appeal to Tahiti and present it to the local population. He began by having it signed first in Tahiti, then took advantage of the first voyage of the boat Tuamotu to travel further afield. The boat, which had been bought by the Tuamotu Islands Cooperative, allowed him to travel to the outermost islands to explain to the islanders the dangers of nuclear arms. $^{8}$

Marie-Thérèse and her Swedish husband, Bengt Danielsson, were newly arrived anthropologists living on the outer island of Raroia in the Tuamotu Archipelago, 740 kilometres northeast of Tahiti. They attended meetings on Raroia organised by Pouvanaa about the horror of nuclear war, which later inspired them to campaign against French nuclear testing, through the publication of their classic polemic Moruroa mon amour. ${ }^{9}$ From the earliest days, the issue of nuclear testing was connected to the right to self-determination for the Maohi people of French Polynesia. Pouvanaa a Oopa had founded the Rassemblement Démocratique des Populations Tahitiennes (RDPT) in November 1949 - the earliest nationalist formation in French Polynesia - and won a seat in the French National Assembly. However during France's 1958 constitutional referendum, he pushed for independence rather than autonomy within the French Republic. This earned him the enmity of the Gaullist regime, as it prepared to shift France's nuclear testing program from the deserts of Algeria to the Tuamotu archipelago. ${ }^{10}$ In a scandal that has been documented by historian JeanMarc Regnault, Pouvanaa was falsely charged with arson and other crimes, deprived of his civil rights and thrown into prison in France. ${ }^{11}$ The charismatic leader - known as the Metua - was exiled from his home for a decade, removed from public life just as France began to relocate its nuclear testing centre in the early 1960s. Pouvanaa's campaign echoed regional protests that had grown since the nuclear age in the Pacific began with the flight of the Enola Gay from Tinian in the Marianas Islands to Hiroshima on 6 August $1945 .^{12}$ 
Administering the UN strategic Trust Territory of the Pacific Islands (TTPI), the US military began Operation Crossroads in 1946, which led to 67 atmospheric nuclear tests at Bikini and Enewetak Atolls. ${ }^{13}$ The greatest international outcry began after the 1 March 1954 nuclear test codenamed Bravo, which spread fallout across the northern atolls of the Marshall Islands. Antinuclear demonstrations were strongest in Japan, because of the irradiation of the $23 \mathrm{crew}$ members of a nearby Japanese fishing boat Fukuryu Maru (Lucky Dragon).

While protests were concentrated in the Pacific Rim, Marshall Islanders also expressed their concern, despite the US Navy's control of the United Nations trusteeship. Islanders led by Dwight Heine and customary chief Kabua Kabua lodged a petition with the UN Trusteeship Council just weeks after the Bravo test, which requested that "all experiments with lethal weapons in this area be immediately ceased." The petition said:

The Marshallese people are not only fearful of the danger to their persons from these deadly weapons in case of another miscalculation, but they are also concerned for the increasing number of people removed from their land....land means a great deal to the Marshallese. It means more than just a place where you can plant your food crops and build your houses or a place where you can bury your dead. It is the very life of the people. Take away their land and their spirits go also. ${ }^{14}$

In 1956, after the UK government announced that British nuclear testing would commence at Christmas Island, Western Samoa petitioned the UN Trusteeship Council to halt the British tests (at the time, Samoa was still a trust territory of New Zealand). The Trusteeship Council rejected the petition by a vote of $9-1$, with only Russia voting in favour. ${ }^{15}$ The same year, the Rarotonga Island Council submitted a report to the Cook Islands Legislative Council, expressing concern about the proposed British tests on Christmas Island and asking "that the testing area be situated at some greater distance than the Cook Islands." ${ }^{16}$ British forces established a weather station on Tongareva (Penrhyn island) in the Cook Islands, which is located just 550 kilometres south of Malden. British naval vessels later transited through Tongareva and reefs were blasted for shipping access (leading to reports of the disease ciguatera at the time of the tests).

In Australia, Aboriginal activists had joined supporters in 1947-48 to protest the establishment of the Woomera rocket testing range in South Australia. In the early 1950s, Britain's nuclear testing program in South Australia was established within the Woomera Rocket Area (WRA) on the lands of the Yankunytjatjara and Pitjantjatjara peoples. Over time, the antiWoomera campaign grew into broader indigenous opposition to nuclear testing. Public meetings, radio broadcasts and information leaflets were organised by the newly formed Council for Aboriginal Rights, supported by the Aboriginal Advancement League (AAL), Communist Party of Australia, Women's Christian Temperance Union, and Women's International League for Peace and Freedom (WILPF). ${ }^{17}$

In Fiji, there was also popular opposition to the proposed British nuclear testing program to the north. In February 1957, the Indo-Fijian newspaper Jagriti editorialised:

People living in the vicinity of the islands where the atom and hydrogen bombs have been tested are afflicted with hazardous diseases. Full information has not been given so far about them. Nations engaged in testing these bombs in the Pacific should realise the value of the lives of the people settled in this part of the world. They too are human beings, not 'guinea pigs'. ${ }^{18}$ 
The Fiji Times, the main English language newspaper in the British colony, gave front-page coverage to international protests against the nuclear tests. An April 1957 editorial in the Fiji Times noted:

Nobody knows how many people will die or how many children will be born mentally or physically deformed because of atomic or hydrogen bomb tests, past or future. That is why there is so much disquiet in so many countries and among so many peoples of varying political beliefs about the continuation of such tests by the United States and Russia and about the forthcoming tests on Christmas Island...The free nations should seek foreign agreement with Russia to curtail or suspend completely all tests until their effects on the future of mankind can be more accurately assessed. To continue with indiscriminate and unrestricted tests in the present state of uncertain knowledge will be irresponsible folly indeed. ${ }^{19}$

\section{Background to Operation Grapple}

With the United States' 1946 McMahon Act restricting the transfer of nuclear research and technology, the British government developed its own testing program in the 1950s, aiming to follow the US and the Soviet Union in the development of atomic and hydrogen bombs. According to Lord Cherwell - a Conservative politician and Winston Churchill's chief scientific adviser - the development of thermonuclear hydrogen bombs was central to maintaining Britain's status as an imperial power in the post-war era:

If we are unable to make the Bomb ourselves and have to rely entirely on the United States for this vital weapon, we shall sink to the rank of a second class nation, only permitted to supply auxiliary troops, like the native levies who were supplied small arms but not artillery. ${ }^{20}$

Britain needed an area with little population to test their nuclear weapons and Churchill's Cabinet searched the map for an isolated outpost of the British Empire. Fearful of opposition from the public, planning was conducted in secret for the British testing program in Australia and the Pacific islands. After the testing of atomic bombs in the deserts of Australia, Britain planned to develop the hydrogen bomb. However the agreement with the Australian government stated that $\mathrm{H}$-bomb trials could not be conducted in Australia for "safety reasons", so the British government was forced to seek a new testing site.

The British Cabinet Defence Committee secretly decided to construct an H-bomb at its meeting on 16 June 1954. By the end of 1956, tens of thousands of tons of equipment had been brought from England to establish the military base on Christmas (Kiritimati) Island in the central Pacific. A forward base and airstrip was also established on Malden Island, located 600 kilometres from the Christmas Island base. At the time, these two islands were part of the British Gilbert and Ellice Islands colony - today, they are within the independent island nation of Kiribati. Nearly 20,000 British military personnel, supported by 524 New Zealand sailors and nearly 300 Fijian soldiers and sailors, travelled to the central Pacific for Britain's hydrogen bomb testing program between 1956 and 1962. At the peak of activity in 1957-8, these forces and civilian scientists were living under canvas on Christmas Island.

Overall, nine atmospheric tests codenamed Grapple were held in 1957-58. In May and June 1957, Britain conducted three nuclear tests near Malden Island, codenamed Grapple 1 (Short Granite), Grapple 2 (Orange Herald), and Grapple 3 (Purple Granite). The nuclear devices were detonated high over the ocean after being dropped from a Valiant bomber - by exploding the bomb in the air rather than on land, it was designed to reduce radioactive fallout. A British naval 
task force and aircraft flown from Christmas Island monitored the tests at Malden Island. The light aircraft carrier HMS Warrior was the command vessel, supported by British warships and two New Zealand frigates, HMNZS Pukaki and HMNZS Rotoiti. Members of the Fiji Royal Naval Volunteer Reserve joined New Zealand sailors aboard the NZ frigates. ${ }^{21}$ Later, from 1958-60, dozens of Fijian soldiers were deployed on land, often working as labourers around the tent city. Official statements issued in London after the tests argued that there had been no radioactive fallout, although the three tests near Malden did actually contaminate the island with significant fallout. $^{22}$

After the tests, the British government announced that it had achieved a thermonuclear explosion in the megaton range. The Mid-Pacific News - a newsletter produced for staff and troops on Christmas Island - reported: "Bomb Gone! H-Bomb puts Britain on level terms." ${ }^{23}$ This was a massive political bluff, however, to persuade the United States to review the McMahon Act and renew scientific collaboration between the two countries that had been ended after a series of British spy scandals. Privately, UK scientists calculated that the blasts were only 0.2 to 0.7 megatons, and further tests were needed. The bluff was successful, with the amendment of the McMahon Act in July $1958 .{ }^{24}$ Facing moves towards an international moratorium on nuclear testing in 1958, there was pressure on the British task force to rush and develop a hydrogen bomb in the megaton range. Rather than send a naval task force and thousands of men back to Malden Island - hundreds of kilometres from the base of operations - it was decided to conduct further tests at Christmas Island:

Because time is so short, it is been decided to carry out the November tests of the southeast tip of Christmas Island; it would have taken too long to set up Malden again. The trials will be high airburst as before. ${ }^{25}$

This decision reduced the enormous logistic problems of conducting the tests so far away from the main base, saving over two million pounds. But it brought the tests close to the camp where British, New Zealand and Fijian personnel were stationed. From August 1957, there was a major build-up of the Christmas Island base. Between November 1957 and September 1958, a further six nuclear tests were conducted in the atmosphere near Christmas Island. During these tests, service personnel were ordered to line up in the open, to face away from the explosions, and remain with their backs turned with eyes closed for twenty seconds after the explosion. At sea, crews lined the decks of the naval task force. On land, soldiers and civilian personnel were grouped on the beaches at various points of the island only 25 miles from the centre of the blast. The local Gilbertese population - labourers and plantation workers - were initially taken offshore during the tests, or housed aboard British naval vessels to avoid the blast.

Much of this activity was conducted in secrecy to avoid public opposition. For example, the official British Colonial Office reports on the Gilbert and Ellice Islands Colony from 1956 onwards make no mention of the construction of the massive military base on Christmas Island or the testing of nuclear weapons! ${ }^{26}$ However, with thousands of personnel involved, there was growing public awareness of the Grapple program. Opinion polls showed that nearly half the UK population were opposed to the tests, and there was growing concern in Australia, New Zealand and Japan. The National Council for the Abolition of Nuclear Weapons Tests (NCANWT) soon had one hundred branches around the United Kingdom (NCANWT was the forerunner of the Campaign for Nuclear Disarmament, which was founded in January 1958). Beyond public advocacy and campaigning in the Labour Party, however, small numbers of socialist and pacifist groups began to plan more direct action against the tests, forming the Emergency Committee for Direct Action against Nuclear War. ${ }^{27}$ From this point, let us delve into the stories of four figures who grappled with the reality of nuclear testing in the Pacific. 


\section{Harold Steele}

One way to track the history of peace protests is through the archives of disarmament groups and socialist organisations. Another is through the archives of Special Branch police and the intelligence services. As detailed in recent studies of the Australian Security Intelligence Organisation (ASIO), the secret state maintains a surprisingly comprehensive compilation of statements from groups perceived to be subversive.$^{28}$ While lacking the rigour of today's cyber monitoring, the UK Public Records Office holds files from the 1950s related to public protests against the Grapple nuclear tests. These include newspaper and wire service clippings, letters, telegrams and diplomatic cables sent between MI5 in London, the Secretary of State for the Colonies, the Governor's office in Fiji, the British Embassy in Tokyo and Foreign Office bureaux in Honolulu and Tahiti. ${ }^{29}$

In March 1957, a six paragraph article in the Daily Worker newspaper sparked MI5's interest, reporting that a 63-year-old "white-haired and keen eyed" ex-poultry farmer from Great Malvern, Worcestershire, intended to "go out to the Pacific and sail into the H-blast area." ${ }^{30}$ With support from other pacifists around the Peace Pledge Union (PPU), Harold Steele and his wife, Sheila, announced they would travel to Tokyo to join a protest fleet to sail to the central Pacific, aiming to halt the Grapple hydrogen bomb tests. In London, the Emergency Committee for Direct Action Against Nuclear War began to raise funds to support the protests, with sponsors including philosopher Lord Bertrand Russell, playwright Laurence Housman and comedian Spike Milligan.

Steele had a long history of pacifism. While studying at Exeter University during World War One, he refused the offer of a commission if he enlisted. As a conscientious objector, believing that "Christianity and socialism forbade any resort to war", he was court-martialled five times during the war and sentenced to seven years' hard labour. ${ }^{31}$ After three years in prison, he was only released in April 1919, long after the war was over. In March 1957, Steele told the Sunday Pictorial newspaper:

The time has come when someone must make a real move to stop the H-bomb tests. My wife and I will willingly sacrifice ourselves to prove to the world the horror of this devilish device. Personal considerations are secondary. My three children - much as I love them are not important. If I should die, I commend them to the care of my Quaker friends. I believe this demonstration will shake the conscience of man out of its lazy acceptance of the $\mathrm{H}$-bomb and all its horrors. ${ }^{32}$

Two other young Britons, David Graham (aged 25) and Ian Dickson (aged 21), were in New Delhi and also planned to go to Japan or Fiji to join the protest. According to correspondence from the British Embassy in Tokyo, both men were war resisters who had refused to be conscripted for national service. Embassy official T.W. Aston reported to London:

According to the Times of India, Graham has already spent a term in jail for refusing to be conscripted. I do not know whether this might give the authorities in Fiji an excuse to frustrate their efforts should this be thought desirable or necessary. ${ }^{33}$

Steele was initially unable to obtain a Japanese visa and in April, the News Chronicle reported that he planned to travel to the Pacific via India. An annotation on the newspaper clipping in the Steele's intelligence file asks: "Any news?" The handwritten response: "Only that he is assessed as a bona-fide pacifist and as a member of the Peace Pledge Union in the past. If he has otherwise subversive links, it would be known. I suggest we write him off." ${ }^{34}$ Officials in the Asia-Pacific 
region remained anxious about whether Steele would manage to travel to the Pacific islands. The archives contain a long series of letters and telegrams between London, Tokyo, Suva, Hawaii and Tahiti trying to track the protesters' movements. A confidential letter from the Foreign Office in London to the British Embassy in Tokyo notes:

In view of the conditions which the Japanese government has imposed for any visit by Steele to Japan, it seemed remotely possible that, if he can raise the necessary funds, this man will try to approach the danger area from some other jumping off point. For this reason we have telegraphed Honolulu and Tahiti asking for news as it comes to notice, since we must take all reasonable measures to prevent Steele from obstructing the tests. ${ }^{35}$

An article in the Fiji Times on 17 April 1957 reported that Steele had booked an air passage to Fiji on 5 May. In a telegram from the Governor's office in Fiji to the Foreign Office on 18 April, marked "immediate and confidential", the Deputy Governor in Suva reported that:

Steele is alleged to have told reporters that he hopes to arouse some kind of protest among the Fijian population against proposed nuclear test in the Pacific area... I should be grateful if you would make appropriate enquiries and inform me whether you consider Steele should be declared to be a prohibited immigrant under section 7(c) of Immigration Ordinance $1947 .{ }^{36}$

The reply from the Secretary of State for the Colonies to the Governor in Fiji noted:

His resources seem very limited and unless he could obtain local backing in Fiji, it is doubtful whether he could do much harm. As it seems unlikely he will come to Fiji it would only create unnecessary publicity to declare him a prohibited immigrant at this stage. In any case it would seem preferable to take action against him under section 8 (5) (b) of Immigration Ordinance if necessity arises. ${ }^{37}$

In the end, Harold Steele was unable to reach Fiji before the first Grapple test on Malden Island on 15 May 1957. He did, however, reach Japan and spent weeks conducting public meetings and newspaper interviews to highlight opposition to the Pacific tests. The Fiji media gave prominent coverage to protests in Japan, such as a front-page report and picture in the Fiji Times of the 15,000-strong rally in Tokyo following the first test on Malden Island. ${ }^{38}$ On Steele's return to England, the Emergency Committee for Direct Action against Nuclear War was transformed into the Direct Action Committee Against Nuclear War (DAC) in April 1958. The DAC launched a generation of civil disobedience against nuclear weapons. ${ }^{39}$

Harold Steele's unfulfilled dream of sailing a boat into the middle of the Pacific nuclear test zone inspired many others: Albert Bigelow's plan to sail the Golden Rule to Enewetak Atoll in the Marshall Islands to disrupt the 1958 Operation Hardtack test series; Earle Reynold's 1958 voyage aboard the Phoenix to waters off Bikini Atoll; the rusting fishing trawler Phyllis Cormack (renamed the Greenpeace), which sailed from Vancouver in 1971 against US tests; the Vega, Fri, Rainbow Warrior and other vessels that bedevilled the French State from the 1960s; or Bill and Lorraine Ethell, who mortgaged their home and took three children aboard the Pacific Peacemaker, which sailed across the Pacific in 1982 to challenge the regional deployment of nuclear-armed US Trident submarines. But those are all stories for another day.

\section{James Burns}


While the tale of pacifist Harold Steele began with a short article in the Daily Worker, the story of Australian businessman James Burns begins with the Sydney Daily Telegraph. On 20 December 1956, Burns noticed a brief story in the Daily Telegraph. It reported that technicians at Edinburgh airfield in Adelaide were fitting 10 Royal Air Force (RAF) Canberra jets with recording instruments, preparing to relocate to Christmas Island to prepare for Britain's hydrogen bomb tests. As noted in the story, "the jets will fly through radioactive cloud." ${ }^{40}$ James Burns was worried because his company Burns, Philp \& Co had extensive plantations in the British Gilbert and Ellice Islands colony. As one of the leading businessmen in the Pacific, Burns could express his concerns about nuclear testing straight to the top. The same day as the Daily Telegraph story, Burns wrote to Minister for Defence Sir Philip McBride, enclosing the clipping and asking for reassurance about his property near the nuclear test site:

In connection with the British government's decision to carry out hydrogen bomb tests at and around Christmas Island, I would like to draw attention to the fact that we have very large plantation interests in Fanning and Washington islands, under 200 miles away from Christmas Island...We would like to point out that there seems to be a difference of opinion as to how far the effect of the hydrogen bombs will be experienced and we would like to have the assurance of the Australian government - if it is participating by fitting Canberra jets with recording instruments for the hydrogen bomb tests - that the employees of our plantations or the plantations themselves will not suffer any ill effects. ${ }^{41}$

Burns, Philp \& Co was created by Scottish merchant Sir James Burns (1846-1923), but his son also named James - joined the family firm at age 17 in 1898. James Burns was appointed a director in 1919 and following his father's death in 1923, he took over as chair and managing director. In the first half of the 20th century, the company expanded operations, with mercantile, shipping, insurance and copra plantations throughout Melanesia, the central Pacific and parts of South-East Asia. ${ }^{42}$ Burns developed a reputation as a buccaneer, as noted by biographer Ken Buckley: "Although conservative-minded, modest and cheerful, Burns was regarded by the administration in Papua-New Guinea as a commercial pirate who sought to use political influence to gain monopolies." ${ }^{43}$

This political influence came to the fore as Burns sought to protect his investments from Britain's nuclear test program. In a letter to Minister for Supply Howard Beale in January 1957, Burns complained that his company had suffered losses during the Second World War, when ordered to destroy 1,000 tonnes of copra and burn plantation houses in the Solomon Islands so they could not be used by advancing Japanese troops. Noting that his company suffered losses "in the vicinity of $£ 250,000$ ", he complained to Beale that Burns, Philp \& Co received "no post-war compensation from the British government for the damage in the Solomon Islands or other Pacific locations." ${ }^{44}$ Burns then pressed Beale for guarantees about potential damage from the British nuclear test series on Christmas Island:

I do hope, if there are any hydrogen bomb 'antics' in the Pacific and our property is damaged, that we will not find ourselves in the same position. I sincerely trust that nothing like this will occur, but there seems to be some diversity of opinion by wellknown scientists as to the effect of the hydrogen bomb that I do think we should be assured by the British government, if any damage does occur to our properties in the Pacific from these tests, the payment for such damage will be sympathetically considered. ${ }^{45}$ 
James Burns was quite right to be concerned, both about the Canberra aircraft and about potential health impacts for his Gilbertese workers. British military authorities tried to hide the fact that the RAF aircraft were contaminated with radioactivity when travelling through Fiji from Australia to Christmas Island. The Canberra bombers from 76 Squadron were used during the Australian nuclear testing program between 1952 - 57. As they collected samples while flying through the mushroom clouds of the atomic tests at Maralinga, the planes' engines were contaminated with radioactivity (The aircrews suffered radiation doses up to six times as high as the current international safety limit for nuclear workers). Then, after the Maralinga tests, five Canberra aircraft flew across the Pacific in October 1957 for the next series of hydrogen bomb tests at Christmas Island. En route, the planes landed at Nadi Airport in Fiji for maintenance and refuelling. A confidential memo from RAF Air Commodore W. P. Sutcliffe - the Commander of the "Antler" nuclear test program in Australia - ordered crews of the RAF bombers not to tell local authorities in Fiji that their engines were radioactive. The memo noted that although the planes had been cleaned on the outside, their engines were still coated with radioactive material on the inside:

Aircraft of the No.76 Squadron flying to Christmas Island and stopping at Nandi [sic] and Canton may be radioactive internally... There appears to be no regulations in force governing the transit of radioactive aircraft through international civil airports such as Nandi and Canton. The fact that an engine may be 'hot' should be concealed from the Nandi authorities unless they ask. ${ }^{46}$

Reports in the British archives also record official attitudes to the indigenous peoples living downwind of the nuclear test sites, highlighting the casual racism that dominated the nuclear era. In November 1956, the Commander of the Grapple Task Force Air Vice Marshall Wilfred Oulton issued a study on the "Danger Area" to be promulgated on 1 January 1957 for the Grapple nuclear tests. The purpose of the study was to define an area to warn off shipping, aircraft or fishing vessels that might intrude in the test zone. It sets "several definitions of levels of radioactivity resulting from fall-out" and looks at the danger of an "accidental surface burst." ${ }^{\prime 7}$ The document reveals that the "acceptable" dosage of radiation was different for British personnel than for the islanders who lived on Christmas Island and on neighbouring inhabited atolls such as Fanning, Jarvis or Penrhyn (Tongareva) in the Cook Islands:

For civilised populations, assumed to wear boots and clothing and to wash, the amount of activity necessary to produce this dosage is more than is necessary to give an equivalent dosage to primitive peoples who are assumed not to possess these habits. For such peoples the corresponding level of activity is called level B'. It is assumed that in the possible regions of fall-out at Grapple there may be scantily clad people in boats to whom the criteria of primitive peoples should apply....The dosage at this [B'] level is about 15 times higher (for primitive peoples) than that which would be permitted by the International Commission on Radiological Protection. ${ }^{48}$

A meeting of officials held a week later to discuss the study agreed "that the levels recommended by the ICRP would necessarily be exceeded." Officials agreed to inform the Minister, however, that "independent authorities agree that ... only very slight health hazard to people would arise, and that only to primitive peoples." ${ }^{49}$ The original version of the Danger Area was a 400 nautical mile circle around the drop-zone, the estimated area for explosions equivalent to 150 kilotons (although many of the actual explosions were much larger than this, ranging up to 3 megatons). Noting that "the proposed Grapple Danger Area is considerably larger than that prescribed for 
similar American tests", some officials argued that "such an area is patently too large and has been reduced." This meant the boundaries of the Danger Area around Christmas Island were artificially re-drawn to exclude inhabited islands, including places where Burns Philp plantations were located, such as Washington, Fanning, Palmyra and Jarvis Island! ${ }^{50}$

James Burns' lobbying in early 1957 prompted extensive discussions amongst British officials on arrangements to take care of the Gilbertese workers after the tests were relocated from Malden to Christmas Island. In a September 1957 letter from the Secretary of State for the Colonies, officials reported:

The proposal is to remove the Gilbertese from Christmas Island before the bombing aircraft takes off and place them in a ship in the Christmas anchorage, which has immediate notice to steam. They will remain in the ship until after the test when they will be returned to their village. Should an accident occur, either due to a crash on take-off by the bomber or surface burst instead of a high airburst, then there may be a risk to ships lying in the anchorage. ${ }^{51}$

As detailed in the next section, the Grapple Y test in April 1958 was indeed a "surface burst instead of a high airburst", with consequences for the "primitive peoples" who witnessed the British nuclear test program on Christmas Island.

\section{Sui Kiritome}

Beyond the workers on James Burns' plantations, about 100 Gilbertese men were employed on Christmas Island between 1956 and 1958. Supporting the thousands of British personnel, they worked as general labourers, laundry assistants and for "sanitary duties [i.e. emptying Elsan toilets], a task of relatively short duration for which extra pay would be awarded." ${ }^{2}$ They lived, together with their families, at Port London village on Christmas Island - a total of about 260 men, women and children. With the tests shifting from Malden Island to Christmas Island in late 1957, there was extensive discussion about ways to reduce costs while increasing the labour force. Staff of Headquarters Task Force Grapple and the Resident Commissioner for the Gilbert and Ellice Islands debated the merits of using Fijians soldiers and sailors from the Fiji Royal Naval Volunteer Reserve (FRNVR) or the Royal Fiji Military Force (RFMF) instead of more Gilbertese labour. The Colonial Office leaned towards creating jobs for Gilbertese islanders, while the military liked the discipline of Fijian reservists recruited into the British Army:

The employment of Fijian reservists does not give rise to any difficulties because they live, eat and play with the UK troops and there are no complications about accommodation or messing. As you know only too well from the Estimates exercise, the Treasury here have strict instructions to keep expenditure to the minimum and it would be difficult to persuade them to agree to the construction of special accommodation if the employment of Gilbertese made this essential. There is also the food problem if the Gilbertese have to be given special rations. ${ }^{53}$

In later meetings, the representative of the Grapple Headquarters Commander "explained that an important consideration was the necessity to evacuate Gilbertese or place them in ships during nuclear tests." However,

The Resident Commissioner stated that his view was that if it was safe for service personnel to stay on the island, it was safe enough for Gilbertese. At the time of the first operation, the High Commissioner had however sought assurances from the Colonial 
Office that there was no danger and these were not then forthcoming in sufficiently explicit terms. ${ }^{54}$

If Gilbertese workers were to be evacuated from the island to the naval task force "it would in any case be necessary for women and children to be placed below decks in a ship, as the children could not be expected to carry out the safety drill." ${ }^{55}$ For the Grapple X nuclear test on 8 November 1957, Gilbertese workers were sent off island to Fanning for three months, except for the teacher, wireless operator and police constables. They had returned to the island, however, in time for the next nuclear test on 28 April 1958, codenamed "Grapple Y". Christmas Island veterans have long argued that the greatest radiation exposure was created by this Grapple Y test, which was a massive explosion estimated at 2.8 megatons. Many reports suggest that the explosion was lower than expected, and the detonation sucked up quantities of water and debris into the mushroom cloud, irradiating them in the process. Irradiated water and debris then fell to ground, contaminating an area estimated at 50 to 100 miles, with fallout reaching the British naval task force, the military camp on Christmas Island and Port London village. ${ }^{56}$

This 1958 nuclear disaster was witnessed by Sui Benan Kiritome, who arrived on Christmas Island in 1957 with her husband Kiritome Itaia, a teacher posted to the island for the schoolchildren of Gilbertese labourers. Kiritome Itaia also served as an interpreter for the British military to help pass on instructions to the islanders. In an interview translated by her daughter, ${ }^{57}$ Mrs Kiritome described events on the day of the Grapple Y test. Local inhabitants of the island were informed just before the test that it was about to take place. Islanders were told to go aboard a British warship, where a movie was screened and sweets provided for the children.

When the countdown to the blast began, my husband told the people to put their hands to their ears to muffle the sound of the blast. Just after the blast, the captain came to my husband and invited us to accompany him to the deck to see what happened after the blast. We went up on deck and we saw everyone on deck wearing protective clothes ... We went on deck wearing normal clothes. We were watching the black cloud and smoke from the blast, which was drifting towards us. When it came overhead, I felt something like a light shower falling on me. I thought it was rain. Sometime after the test, something happened to my head and face. Every time when I combed my hair, I was losing strands of my hair and something like burns developed on my face, scalp and parts of my shoulder. My face was the worst affected because I was looking up at the black cloud from the blast, which was directly above us when the light shower fell on my face ... The mark remains on my face till today. It has been on my face for the last 40 years or so now. ${ }^{58}$

As she stood on the deck of the British warship, Sui Kiritome was six months pregnant. Given "the black cloud and smoke from the blast", Mrs Kiritome was anxious about possible health impacts when her daughter Rakieti was born in July 1958:

A strange thing happened during her birth. Blood came out from all cavities in her body from her eyes, nose, year...I was told by my husband that the doctor was very surprised to see what happened to the child. ${ }^{59}$

As the Grapple series progressed, the Headquarters Task Force Grapple abandoned elaborate safety procedures for the islanders. For two of the smaller Grapple Z tests ("Pennant" on 22 August 1958 and "Burgee" on 3 September 1958), the Gilbertese workers and their families "were marshalled ashore in a safe place" even though the officials acknowledged that anyone who 
deliberately or accidentally observed the initial flash of the nuclear test was "likely to have their eyesight temporarily or permanently impaired." ${ }^{\prime 60}$

\section{Paul Ah Poy}

The Grapple Y disaster was witnessed by another Pacific islander, who later became an active campaigner for the rights of nuclear test survivors - Fijian sailor Paul Ah Poy. He first travelled to Christmas Island in 1956 about HMNZS Lachlan, as the NZ warship surveyed the island in the build-up to the test. In July 1957, as a member of the Fiji Royal Naval Volunteer Reserve, he returned to Christmas Island and went on to witness seven nuclear detonations during Operation Grapple. ${ }^{61}$ Forty years after the tests, Ah Poy vividly described his recollection of the heat and blast as a nuclear weapon exploded into the sky over the atoll:

I could see the flash of white light through my closed eyelids and the palms of my hands and the searing heat through my shirt on my back. I started squirming, then stood up and turned around. First thing I saw was a big new sun. Then slowly it turned into a giant ice cream cone with white cream dripping over its side. Then into a giant mushroom cloud. ${ }^{62}$

For many young men, the opportunity to leave Fiji for the first time was a huge adventure, but many former Fijian soldiers who witnessed the Grapple nuclear tests have testified that they were exposed to radiation hazards. As detailed in the book Kirisimasi, anxiety about possible long-term effects from radiation exposure continued for decades for the surviving Fijian military personnel who staffed the test sites from 1957 to $1960 .{ }^{63}$ Some members of the contingent have died from cancer, leukaemia or other serious illnesses and the surviving veterans report a range of medical complaints which they attribute to their service on Christmas Island.

From oral testimony and archival research, there is evidence that the troops were placed in hazardous environments which increased the risk of exposure to ionising radiation. After each nuclear test, Fijian military personnel were involved in clean-up operations, including disposing of thousands of birds that were maimed, blinded or killed by the nuclear explosions. Limited protective gear was issued to some troops for the early tests (such as white cotton suits to reduce the risk of flash burns). Most veterans testified, however, that they never received such gear, and served their term wearing standard army boots, shorts and shirts. The Fijians ignored British regulations that banned fishing and caught fish and crabs that may have been contaminated. ${ }^{64}$

Beyond the clean up after each test, Ah Poy helped to dump drums of radiationcontaminated waste into the ocean from a small boat. ${ }^{65}$ Like other Grapple veterans, he later suffered a number of health problems that he attributed to exposure to radiation in the 1950s. As well as the loss of hair and damage to his fingernails soon after the tests, Paul developed a rare skin disease. After his wife miscarried three times, his second daughter was born physically retarded and died at the age of three and a half. The failure of the British government to conduct medical studies before and after the tests reinforces the difficulty of documenting the changes in the veterans' health. In an interview, Fijian veteran Emori Ligica noted: "We were all medically examined and were healthy when we left for Christmas Island. When we returned we were never medically checked." ${ }^{66}$ The Fijians suggested there was little evidence of racism amongst rank and file troops. This sentiment was echoed by Scottish veteran, Ken McGinley, who said the young Fijian soldiers were popular with the British troops:

The Fijians were the most friendly bunch that you could ever meet and they were really easy to get along with. They weren't allowed any alcohol from the NAAFI, so we always bought them a couple of cases of beer and they, in turn, taught us how to catch crayfish 
and lobster. Sometimes they would come over to our tents and sing a few songs for us while one of them strummed a guitar. ${ }^{67}$

The troops' attitude to senior officers, however, was not so enthusiastic. Nuclear veterans across the region complained that they were used as guinea pigs - a claim ridiculed by authorities. Well before the nuclear tests, senior members of the British military bureaucracy clearly saw that personnel could be exposed to radiation as part of the nuclear test program. Documentary evidence from the UK archives shows that one of the purposes of the tests was to study the effects of nuclear detonations on personnel and equipment - similar evidence can be found in the French and US archives. For example, the British Chiefs of Staff had a Defence Research Policy Committee on the Atomic Weapons Trials, looking at the military applications of atomic energy. A memo from the committee, dated 20 May 1953, stated that a series of "tests" needed to be included in future atomic weapons trials:

The Navy requires information on the effects of various types of atomic explosions on ships and their contents and equipment...The Army must discover the detailed effects of various types of explosion on equipment, stores and men, with and without various types of protection $^{68}$

And a memo from the Royal Air Force, dated 29 November 1955, stated: "During the 1957 trials, the RAF will gain invaluable experience in handling the weapons and demonstrating at first hand the effects of nuclear explosions on personnel and equipment." ${ }^{69}$

From the 1950s to today, the British, New Zealand and Fijian veterans have faced pennypinching by the British authorities. Files in the UK Public Records Office are full of correspondence from the 1950s between the Grapple Task Force, the Ministry of Supply in London, the commander of the Fiji Military Forces in Suva and the Colonial Office all seeking to shift costs for the employment of islander labour. ${ }^{70}$ In a comical but telling example, a draft letter from the Ministry of Supply to the Governor of Fiji asked "on what grounds it is considered that Fijian newspapers and supplies of kava should be provided at public expense." ${ }^{\text {11 }}$ Six months later a letter from the Ministry of Supply in London to the Colonial Office noted:

You will recall that we took up with the Commander FMF, among other matters, the question of supplies of yaqona [kava], dalo [taro] and Fijian newspapers to the above troops. We have received a reply which we regard as generally satisfactory on these points with the exception of the proposed man day rate for supplies of yaqona...I should be grateful for a quick reply as I am holding up a further Fijian claim for payment. ${ }^{72}$

At the time Fijian soldiers were recruited for service on Christmas Island in 1958, the Secretary of State for the Colonies guaranteed the Governor of Fiji that the UK government would undertake the costs. This included any indemnity claims for disability pensions arising from injury. Over the next six months, there was extensive correspondence between the Ministry of Supply, Treasury, the Government Actuary and other officials to clarify this indemnity. ${ }^{73}$ By June 1958, the Ministry of Supply wrote to the Government Actuary Office clearly stating that:

The Ministry of Supply has undertaken to indemnify the Government of Fiji against claims for pensions to which men of the Fijian Military Forces or their dependants may become entitled to as a result of death or injury sustained by them during their service on the Nuclear Weapons Testing Base at Christmas Island in the Pacific. ${ }^{74}$ 
Decades later, Paul Ah Poy and other young men who supported God, King and Empire have become bitter about the British government's refusal to recognise their role, let alone provide pensions or even token compensation. Because it was a peacetime operation, Fijian veterans of the Grapple contingent were not eligible for post-independence Fiji's Aftercare Fund, a pension scheme for personnel who served in overseas military operations. This gap was only rectified by Fiji government legislation in 1999, after the publication of the oral history Kirisimasi highlighted their plight. ${ }^{75}$ Some veterans have become committed disarmament activists. Ah Poy has travelled to England to lobby Parliamentarians alongside members of the British Nuclear Test Veterans Association (BNTVA). On 20 October 1999, he stood in the British House of Commons at a meeting with MPs, to state:

I have journeyed far from the other side of the world to bring to you the testimony of what is left of the men and family of the Fijian soldiers and sailors and i-Kiribati...I get sick regularly, with pain from my feet to my back, which I believe is related to the nuclear tests. This sickness has troubled me a lot. I have very little time for my gardens. We should be remembered, because we took Fiji's name there, we went as Fiji soldiers. ${ }^{76}$

Ah Poy also travelled to Tahiti, to meet survivors of French nuclear testing. In 2006, he participated in activities commemorating the 40th anniversary of the first French nuclear test on Moruroa atoll, organised by Moruroa e Tatou, the association of former Maohi workers who staffed the French nuclear test sites.

Scottish veteran Ken McGinley would go on to be BNTVA Chair and to launch one of the first court cases against the British government, seeking compensation for health issues attributed to exposure to radiation. In 1997, McGinley and another veteran lodged a case before the European Court of Human Rights in Strasbourg, which recognised the merits of their claims but sent them back to the United Kingdom to use all relevant avenues of appeal. ${ }^{77}$ On 23 December 2004, a test case for UK, NZ and Fijian veterans of the Christmas Island nuclear tests was lodged before the British courts, seeking compensation for health effects attributed to exposure to radiation during their military service. In June 2009, High Court judge Mr Justice Foskett ruled that ten test cases out of 1,011 claims could proceed to full trial, allowing Britain's atomic test veterans to claim damages. However the UK Ministry of Defence appealed the Foskett High Court ruling and continues to resist pleas for a negotiated settlement.

Former sailor Pita Rokuratu represented the Fijian veterans in the ongoing test case, having been diagnosed with aplastic anaemia and leucopenia as well as skin growths. Rokuratu had little sentiment left for God, King and Country after witnessing three tests on Christmas Island:

I can say that Britain murdered us. All the illnesses are affecting my children and grandchildren. Britain should do something to thank us. It has achieved its aims. It now has a great deal of power. It has an obligation to those who risked or gave their lives. It's true that we Fijians are always up to any challenge. Colonial days are over now. We have a time of enlightenment. Something should certainly be done. ${ }^{78}$

More than ten years after it began, the still unresolved case has wound its way through the UK High Court, the Court of Appeal and Supreme Court. In November 2014, the veterans won a crucial ruling in the Upper Tribunal, which establishes guidance that could see ex-servicemen involved on Christmas Island and Maralinga in the 1950s receive war pensions after suffering chronic ill health. Most of the veterans, however, have died or are too elderly to benefit from any compensation. Because of this delay, the Fiji government decided to compensate surviving Fijian 
soldiers and sailors - and their dependants. In a ceremony in January 2015, Fiji Prime Minister Voreqe Bainimarama highlighted the refusal of successive British governments to address the health and environmental consequences of its nuclear testing program in Australia and Kiribati:

Fiji is not prepared to wait for Britain to do the right thing. We owe it to these men to help them now, not wait for the British politicians and bureaucrats. You may ask: why is Fiji taking responsibility for something that is the fault of Britain? My answer is this. Too much time has passed. The ranks of these survivors are rapidly thinning. Too many men - our fellow Fijians - have gone to their graves without justice. ${ }^{79}$

In his speech on 30 January, Bainimarama - the son of a Christmas Island nuclear veteran stated:

We salute you for following your orders at the time, the orders of a colonial power pursuing its own agenda in the world. You are a living testament to our determination to never again allow our pristine Pacific environment to be violated by outside powers in such a destructive and terrible manner. ${ }^{80}$

Nic Maclellan works in the Pacific Islands as a correspondent for Islands Business magazine (Fiji) and has co-authored three books on nuclear issues in the islands region: La France dans la Pacifique (Editions la decouverte, Paris), After Moruroa - France in the South Pacific (Ocean Press, New York and Melbourne) and Kirisimasi (PCRC, Suva).

\section{Endnotes}

${ }^{1}$ For overviews, see Barbara Rose Johnston and Holly Barker, Consequential Damages of Nuclear War - the Rongelap report (California: Left Coast Press, 2008); Jack Niedenthal, For the good of mankind - a history of the people of Bikini and their islands (Majuro: Micronitor, 2001).

${ }^{2}$ The official British history is Lorna Arnold, A Very Special Relationship - British Atomic Weapons Trials in Australia (London: Her Majesty's Stationary Office, 1987). For a more recent critical study, see Frank Walker, Maralinga (Sydney: Hachette Australia, 2014).

${ }^{3}$ Ken McGinley and Eamonn P. O'Neill, No Risk Involved - the Ken McGinley story - survivor of a nuclear experiment (Edinburgh: Mainstream Publishing, 1991); Gerry Wright, We were there - Operation Grapple (New Plymouth: Zenith Press, n.d.).

${ }^{4}$ Bruno Barrillot, Les essais nucléaires françaises 1960-1996 (Lyon: CDRPC, 1996); Bruno Barrillot, L'Héritage de la bombe (Lyon: CDRPC, 2003).

${ }^{5}$ For discussion of historic and contemporary protests by Pacific Islanders, see Stewart Firth, Nuclear Playground (Sydney: Allen and Unwin, 1987); and Nic Maclellan, Banning nuclear weapons - a Pacific islands perspective (Melbourne: International Campaign to Abolish Nuclear Weapons, 2014), report presented to the second International Conference on the Humanitarian Impacts of Nuclear Weapons, Nayarit, Mexico, February 2014.

${ }^{6}$ While living in Fiji in the late 1990s, the author conducted archival research and interviews as part of a campaign to support Fijian nuclear veterans who witnessed the Grapple nuclear tests in Kiribati. This paper draws on the 1999 oral history co-authored with colleagues from the Pacific Concerns Resource Centre (PCRC) in Fiji, and introduces new material from the UK Public Records Office and other archives. See Losena Tubanavau-Salabula, Josua M. Namoce and Nic Maclellan, eds., Kirisimasi: Na Sotia kei na Lewe ni Mataivalu e Wai ni Viti e na vakatovotovo iyaragi nei Peritania mai Kirisimasi (Suva: PCRC, 1999).

${ }^{7}$ For the effects of nuclear testing on indigenous women in South Australia, see Yalata and Oak Valley communities with Christobel Mattingley, Maralinga - the Anangu story (Sydney: Allen and Unwin, 2009); 
for Fijian troops at Britain's Christmas Island nuclear tests, see Tubanavau-Salabula et al: Kirisimasi; Pieter Van der Vlies and Han Seur document Polynesian workers' experiences during thirty years of nuclear testing in the French Pacific in Moruroa and Us (Lyon: CDRPC, 1997), a collection also available in French and Tahitian.

${ }^{8}$ Danielsson, interview with author, Papeete, Tahiti, September 1999. For further memories of Pouvanaa by the late Marie- Thérèse Danielsson see Nic Maclellan, ed., No Te Parau Tia, No Te Parau Mau, No Te Tiamaraa - for justice, truth and independence (Suva: PCRC, 1999), 18-19.

${ }^{9}$ Marie-Thérèse and Bengt Danielsson, Moruroa mon amour (Paris: Stock, 1974), republished in English as Poisoned reign (Ringwood: Penguin, 1986). For stories of their time on Raroia, see Bengt Danielsson, The Happy Island (London: George Allen and Unwin, 1952).

${ }^{10}$ Jean-Marc Regnault, La bombe française dans le Pacifique - l'Implantation 1957-1964 (Papeete: Scoop éditions, 1993).

${ }^{11}$ Jean-Marc Regnault, Te Metua - l'échec d'un nationalisme Tahitien 1940-64 (Papeete: Polymages, 1996); Jean-Marc Regnault, Pouvanaa a Oopa - victime de la raison d'Etat (Papeete: Les Editions de Tahiti, 2003).

${ }^{12}$ Nic Maclellan, "The nuclear age in the Pacific", The Contemporary Pacific, 17, no.2 (2005): 363-372.

${ }^{13}$ Jonathan Weisgall, Operation Crossroads - the atomic tests at Bikini Atoll (Annapolis: Naval Institute Press, 1994).

${ }^{14}$ Petition from the Marshallese People Concerning the Pacific Islands: "Complaint regarding explosions of lethal weapons within our home islands to United Nations Trusteeship Council, 20 April 1954", circulated as UN Trusteeship Council document T/PET.10/28, 6 May 1954.

15 "UN will not stop Pacific H-bomb test", Fiji Times, 23 July 1956, 1.

${ }^{16}$ Proceedings of the Legislative Council of the Cook Islands, no. 3, 1956. See David Stone, "The awesome glow in the sky: the Cook Islands and the French nuclear tests", Journal of Pacific History, 2, no.1 (1967), 154-5.

${ }^{17}$ Bain Attwood, Rights for Aborigines (Sydney: Allen and Unwin, 2003), 149-150.

${ }^{18}$ Editorial, Jagriti, 20 February 1957. Cited in Brij Lal, Broken waves - a history of the Fiji islands in the 20th century, Pacific Islands Monograph Series no. 11 (Honolulu: University of Hawaii Press, 1992), 158.

${ }^{19}$ Editorial, "Bomb tests", Fiji Times, 4 April 1957.

${ }^{20}$ Margaret Gowing, Independence and deterrence, vol. 1 (London: Macmillan, 1974), 407.

${ }^{21}$ Gerry Wright, We were there - Operation Grapple (New Plymouth: Zenith Press, n.d.).

${ }^{22}$ Two soldiers spent two days retrieving monitoring instruments from ground zero on Malden, which showed high readings of radiation - one of the men developed generalised blisters and was evacuated. Denys Blakeway and Sue Lloyd Roberts: Fields of thunder - testing Britain's bomb (London: George Allen and Unwin, 1985) 157.

23 "Bomb gone! H-Bomb puts Britain on level terms", The Mid-Pacific News, special souvenir edition, 15 May 1957.

${ }^{24}$ Norman Dombey and Eric Grove, "Britain's thermonuclear bluff", London Review of Books, 22 October 1992. For discussion of this thesis, see John Baylis, Ambiguity and Deterrence - British Nuclear Strategy 1945-64 (Oxford: Clarendon Press, 1995), 260-268.

${ }^{25}$ P. Rogers, Secretary of State for the Colonies, 20 September 1957, letter marked Top Secret, file CO136/283, UK PRO.

${ }^{26}$ British Colonial Office, Gilbert and Ellice Islands Colony and the Central and Southern Line Islands Report for the Years 1956 and 1957 (Her Majesty's Stationary Office, London 1959) and Report for the Years 1958 and 1959 (Her Majesty's Stationary Office, London 1961).

${ }^{27}$ Lawrence Wittner, Resisting the bomb - a history of the world disarmament movement, 1954-70, vol. 2 (Stanford: Stanford University Press, 1997), 44-45.

${ }^{28}$ Mark Aarons, The Family File (Melbourne: Black Ink, 2010); Meredith Burgmann, ed., Dirty Secrets - our ASIO files (Sydney: New South Publishing, 2014).

${ }^{29}$ Newspaper clippings, telegrams and telexes cited in this section are collated in "Protests against the $\mathrm{H}$ bomb tests in the Pacific", file CO 1036/513, UK Public Records Office (PRO).

30 "Will sail to H-test area", Daily Worker, 19 March 1957, annotated and filed in file CO 1036/513, UK PRO. 
${ }^{31}$ Biography in Commemorative Program, International Conscientious Objectors Day ceremony, London, 15 May 2014.

32 "We will risk our lives to prove the bomb is evil", Sunday Pictorial, 24 March 1957.

${ }^{33}$ T. W. Aston, British Embassy, Tokyo, to H. C. Hainsworth, Permanent Undersecretary's Department, Foreign Office, London, 10 May 1957 (marked "Restricted Def.55/66/50"), UK PRO.

34 "H-protester says: 'I'll try India"', News Chronicle, 27 April 1957, with file copy annotated in officials' handwriting.

${ }^{35}$ H. C. Hainsworth, Permanent Under-secretary's Department, Foreign Office, London to R.W. Selby, British Embassy, Tokyo, 27 April 1957 (marked "Confidential 212/244”).

${ }^{36}$ Inward telegram from Fiji to the Secretary of State for the Colonies: "Immediate confidential number 105", 18 April 1957, registered in London 20 April 1957.

${ }^{37}$ Outward telegram from the Secretary of State for the Colonies to Sir R. Garvey, Fiji, "Priority/confidential number 105", 26 April 1957, (marked "Confidential Pac/Au 3").

38 "Tokyo H-bomb protest", Fiji Times, 31 May 1957, 1.

39 "Two protests against the hydrogen bomb 1957", appendix XI in Andrew Bone, ed., Détente or destruction 1955-57, collected papers of Bertrand Russell, volume 29 (New York: Routledge, 2005).

40 "Preparing for H-blast", Daily Telegraph, 20 December 1956.

${ }^{41}$ James Burns to Sir Philip McBride, Australian Minister for Defence, 20 December 1956, copied to the Secretary of State for the Colonies in London, file CO 1036/513, UK.

${ }^{42}$ Ken Buckley and Kris Klugman, The Australian presence in the Pacific - Burns Philp 1914-1946 (Sydney: George Allen and Unwin, 1983).

${ }^{43}$ Ken Buckley, "Burns, James (1881-1969)", Australian Dictionary of Biography, vol. 13 (Melbourne: Melbourne University Press, 1993).

${ }^{44}$ James Burns to Howard Beale, Australian Minister for Supply, 9 January 1957, 1.

${ }^{45}$ Ibid., 2.

46 "Transient Canberras of No.76 Squadron - Nandi and Canton", Memorandum from Air Commodore W. P. Sutcliffe (Services Commander, Task Force "Antler"), 13 October 1957, marked "Confidential - UK eyes only”. ATF/S.5014/Air. See Rob Edwards, "Plane deceit”, New Scientist, 8 May 1999.

47 "Danger Area", paper by Air Vice Marshall W.E Oulton, 19 November 1956, Number GRA/TS.1008/1/Air. Only 14 copies of the paper, marked "Top Secret - Guard", were prepared for the British Army and Navy, the Colonial Office, Commonwealth Relations Office and other authorities.

${ }^{48}$ Ibid., 2-3.

${ }^{49}$ Minutes of meeting on 27 November 1956, marked "Top Secret - UK Eyes Only", XY/181/ 024, UK PRO.

${ }^{50}$ Thanks to Professor Wadan Narsey for this insight. "Raw deal for nuke test Guinea Pigs", Sunday Times (Fiji), 13 June 1999.

${ }^{51}$ P. Rogers, Secretary of State for the Colonies, 20 September 1957, marked Top Secret, file CO136/283, UK PRO.

52 "Employment of local labour in Operation Grapple", note prepared by Task Force Grapple for discussions with his honour M.L. Bernacchi CMG OBE, Resident Commissioner Gilbert and Ellis Islands colony, 26 March 1958. Grapple archives GRA/S.102/36/ORG, appendix A, UK PRO.

${ }^{53}$ M.P. Hall, Pacific Department, Colonial Office to Sir John Gutch, Government House, Honiara, British Solomon Islands Protectorate, 14 February 1958. file PAC 310/4/012, UK Public Records Office.

54 "Employment of Gilbertese labour and Fijian military personnel at Christmas island", minutes of a meeting held at Headquarters Task Force Grapple, 26 March 1958. Grapple archives GRA/S.102/36/ORG, UK Public Records Office, 1-2.

${ }^{55}$ Ibid., 2.

${ }^{56}$ For eyewitness testimony and photos, see Ken McGinley, No Risk involved, 57-68.

${ }^{57}$ This section is based on an interview with Sui Kiritome, Tarawa, September 1998, with thanks to her daughter Rakieti and son-in-law Uentabo Neemia-McKenzie. The full interview is published in TubanavauSalabula, Namoce and Maclellan, eds., Kirisimasi, 59-61.

${ }^{58}$ Ibid., 60.

${ }^{59}$ Ibid., 61. 
${ }^{60}$ Captain J.G.T. Westan, Headquarters Task Force Grapple, memo to H.P. Hall, Colonial Office, London, 5 November 1958, file CO 1036/284, UK PRO.

${ }^{61}$ Handwritten statement of Paul Ah Poy's service history, dated 27 March 1998, in author's files.

${ }^{62}$ Paul Ah Poy, interview with author, Suva, 1998.

${ }^{63}$ Tubanavau-Salabula, Namoce and Maclellan, eds., Kirisimasi.

${ }^{64}$ Joseva Vueti interview with author and Losena Salabula, Suva, 1997. See Tubanavau-Salabula, Namoce and Maclellan, eds., Kirisimasi, 46.

${ }^{65}$ Paul Ah Poy, Interview.

${ }^{66}$ Tubanavau-Salabula, Namoce and Maclellan, eds., Kirisimasi, 151.

${ }^{67}$ Ken McGinley and Eamonn P. O’Neill, No Risk Involved, 50.

68 "Chief of Staff's Committee - Atomic Weapons Trials: Reports by the Defence Research Policy Committee", memo labelled TOP SECRET, 20 May 1953, COS (53) 257, UK PRO.

69 "Atomic weapons trials and training - Joint Operations", memo by Group Captain SWB Menault, Royal Air Force, 29 November 19, CMS.2680/55/DD Ops (AWT), UK PRO.

70 "Proposal to use Fijian military forces on Christmas Island", file PAC 310/4/012, UK PRO.

71 "Fijian troops at Christmas Island", Draft telegram to the Governor of Fiji, annex A to Ministry of Supply letter to D.J. Derx, Colonial Office, London, 29 January 1959. File DB/231/05, UK PRO.

72 "Fijian troops at Christmas Island", letter from T. D. Donaldson, Ministry of Supply, to D.J. Derx, Colonial office, London, 18 June 1959, UK PRO.

${ }^{73}$ Collated in file PAC.310/4/012, UK PRO.

${ }^{74}$ G.M.P. Myers, Ministry of Supply, to C.E. Clarke, Government Actuary's office, 5 June 1958.

75 "House passes bill to cater for Christmas Island veterans", Fiji Sun, 14 December 1999; "Bill for former soldiers passed", Fiji Times, 14 December 1999; "Fiji soldiers guinea pigs in nuclear testing", Fiji Sun, 14 December 1999. The Fiji government also agreed the nuclear veterans could access free medical care at the Fiji Military Forces hospital.

${ }^{76}$ Speech by Paul Ah Poy, UK House of Commons, London, 20 October 1999. Copy in author's files.

${ }^{77}$ Judgement, Case of McGinley and Egan $v$ the United Kingdom, European Court of Human Rights, Strasbourg, France, 9 June 1998, (10/1997/794/995-996).

${ }^{78}$ Pita Rokoratu, interview with Josua Namoce, Suva, 1998. See Tubanavau-Salabula, Namoce and Maclellan, eds., Kirisimasi, 46.

${ }^{79}$ Speech by Prime Minister Voreqe Bainimarama, 30 January 2015. http://www.fiji.gov.fj/Media-Center/Speeches/HON-PM-BAINIMARAMA-SPEECH-AT-THE-FIRSTPAY-OUT-TO-.aspx

${ }^{80}$ Ibid. 
Jonathan Strauss, "The Australian Nuclear Disarmament Movement in the 1980s", Proceedings of the 14th Biennial Labour History Conference, eds, Phillip Deery and Julie Kimber (Melbourne: Australian Society for the Study of Labour History, 2015), 39-50. ISBN: 978-0-9803883-3-6.

\title{
The Australian Nuclear Disarmament Movement in the 1980s
}

\author{
Jonathan Strauss ${ }^{\star}$
}

In the 1980s, a large, diverse and vibrant nuclear disarmament movement arose in Australia. This paper uses findings from archival research and interviews conducted by the author over several years to show that strategy in the movement was contended and the movement's debates and internal development had a substantial impact on its rise and decline. The views of movement activists about how to campaign for its demands, such as an end to uranium mining and, especially, for the closure of nuclear war-fighting bases in the country, differed greatly. The appearance of the Nuclear Disarmament Party highlighted divergent views that had arisen in the movement about how to relate to the Australian Labor Party. A potential for alternative political and social leadership underlay the insurgent movement's arguments.

For the last four or so decades, the numbers of people that social movements in Australia have been able to mobilise in protest actions has tended to grow, although the movements have become less sustained and have not provided the same context for political radicalisation. In antiwar campaigns, this can be found in the journey from the Vietnam Moratoriums to the February 2003 marches against the second Gulf War. In between, in the 1980s, the Australian nuclear disarmament movement has been part of this. Its annual (March or April) Palm Sunday marches rallied in the nation's biggest cities and many regional centres. These grew year by year, from an estimated 100,000 participants in 1982 to more than 300,000 in 1984 and 350,000 in 1985 - much larger than the Moratoriums - before beginning to decline, and then stopping altogether after 1990. As well, numerous and varied groups organised around or supported its campaign for nuclear disarmament, their actions only loosely coordinated beyond the local level. ${ }^{1}$ At the movement's height, the Nuclear Disarmament Party (NDP) was created, spurred by the movement's inability not only to achieve its aim under either the Liberal government in the early 1980s, but also under the Labor government elected in 1983. ${ }^{2}$ This marked the emergence of significant electoral opposition to the Australian Labor Party (ALP) to its left, with continuities to the Australian Greens. Yet the NDP was opposed by many - more likely, most - of the movement's acknowledged leaders. This points to drivers of the insurgent movement's dynamics, alongside the flow and ebb of the Cold War during the decade which is generally identified in discussion of the movement. The influence of those who sought opportunities for reforms through the ALP as part of the existing political system, emergent radicalism within the movement, and their conflict, played a key role in the movement's development and decline.

The difficulties many encounter in analysing the 1980s nuclear disarmament movement in Australia largely flow from disregarding its interior development. Its emergence played down the campaign against uranium mining, contrary to the view of James Walter, and earlier Malcolm Saunders and Ralph Summy, that the movement re-emerged after 1977 combined with that campaign. Not only Walter, but Lawrence Wittner, suggested that opposition to US bases was a focus of the movement. However, in practice this demand was contentious within the movement. ${ }^{3}$ Walter also confusingly identified the loss of the anti-uranium struggle in the ALP, "especially ... the 1986 [ALP government's] decision to sell uranium to France", with a consequent shift in the 
focus of the movement's protest to opposition to US bases. The impact of ALP policy in the movement was evident well before that decision. ${ }^{4}$ Brendan Carins recognised this: according to him, attitudes to the ALP were sharply divided in the movement, sapping its dynamism, while the movement's "rank and file" successfully combined their forces in the rise of the NDP. However, he argued that the movement's potential to achieve change "was limited by its narrow middleclass support base", which found a reflection in the dominant part of the movement's leadership's support for the ALP. ${ }^{5}$ Yet he failed to acknowledge that he calle the movement's base and the movement's rank and file were the same, or to discuss any alternative leadership in the movement. Thus, he did not allow for the possibility posed by the insurgent social movement the development of alternative social movement and political leadership (for him, the NDP aspired to pressure the ALP, which was the "only mass-based force for political change"6).

A feature of the 1980s nuclear disarmament movement in Australia was that it developed unevenly across the country. A key organisation, People for Nuclear Disarmament (PND) in Victoria, the structure of which consisted of individual memberships (for example, 1500 in 1985) and group affiliations, was founded in October 1981. Its formation broadened the movement's leadership there: in particular, it involved independent socialist and other radical academics who came into the movement through a peace studies organisation. Among the larger movement organisations, PND was the first to call for the immediate closure of US bases in Australia. It also eventually adopted, in a close vote, a policy of opposition to Australia's military alliance with the US. For several years PND did not affiliate to the Australian Coalition for Disarmament and Peace (ACDP), the movement's national organisation, although PND took part in ACDP national consultations. Other statewide organisations eventually had similar structures and often took the People for Nuclear Disarmament name. But these came about in different ways: for example, NSW PND evolved out of the Assocation for International Cooperation and Development, a preexisting peace organisation. Also, neither their breadth of leadership nor their discussion of aims appears to have progressed to the same extent. For these reasons, what happened in Victoria is a particular focus here. ${ }^{7}$

\section{A revived movement}

Australia has a long history of anti-militarism. From 1980, activists responded to overseas developments, such as the renewed arms race of the "second Cold War" and the upsurge of opposition to that shown by large demonstrations in Western Europe and the US. They also wanted to end the Australian contribution to US nuclear war-fighting capabilities. A number of articles argued for a renewal of the nuclear disarmament movement. ${ }^{9}$

In Victoria, Joe (Joseph) Camillieri put the idea of a coalition of existing forces to closed meetings of three groups: Pax Christi, the Congress for International Co-operation and Disarmament (CICD) and the Victorian Association for Peace Studies. These decided to form PND and organise a public meeting in October 1981. Several church and women's peace and antinuclear organisations were then invited to be PND founding organisations. The anti-uranium organisation, Movement Against Uranium Mining (MAUM), was excluded from this process: MAUM activists subsequently joined PND, but were bitter, and fearful that uranium issues had been downgraded in importance (indeed, anti-uranium demands, when maintained in the nuclear disarmament movement, were never most prominent, although in practice they remained an important political catalyst). ${ }^{10}$

There was no simple continuity between the anti-uranium mining movement that began in the 1970s and the 1980s nuclear disarmament movement. Among other things, the 1980s movement had a much greater capacity to mobilise. The Palm Sunday marches grew from about three or four times, to ten-fold or more, larger than previous efforts. ${ }^{11}$ Behind that lay a mushrooming organisational effort. Alongside the long-standing peace organisations and anti- 
uranium groups such as MAUM and Friends of the Earth, unions, religious bodies, political organisations, international solidarity groups and other existing organisations affiliated to state anti-nuclear coalitions (for example, PND had 150 affiliated organisations in July 1983), and many new peace groups formed, such as:

- Occupational groups, most of which were professionally-based. The medical practitioners' group was founded in 1981 and had more than 1000 members by the beginning of 1984. Lawyers' peace groups formed in Sydney, Adelaide, Perth, Hobart and Canberra between 1984 and 1986. There were some employee groups, backed by unions, including one among metalworkers and another among public servants in the veterans' affairs department.

- Women's groups, which were typically informed by a radical feminism that opposed global violence, including violence against women.

- $\quad$ Student groups, first at some universities and then, beginning in 1983, among secondary students. By 1985 the latter had progressed to the point where a group in Canberra hosted a national conference, attended by two groups from both Sydney and Melbourne and one each from Adelaide and Perth.

- Local groups based on suburbs or regional towns. There were, for example, 12 of these in WA in the middle of 1984, and 75 in Victoria in 1985.

A 1985 list of peace groups named more than $350 .{ }^{12}$

The political orientation of the initial leadership of the nuclear disarmament movement was to support and influence the ALP, where the anti-uranium campaign had earlier succeeded in securing a policy opposing uranium mining. Indeed, many of those who had established profiles as peace and nuclear disarmament activists were ALP members and supporters, or members or supporters of smaller parties, such as the Communist Party of Australia (CPA), which had that orientation. A 1986 survey of people in the workforce found that more than two-thirds of respondents who belonged to nuclear disarmament groups stated they were ALP supporters. ${ }^{13}$ At a 1985 public meeting, ALP Senator Bruce Childs spoke of "us, ... custodians of the peace movement". ${ }^{14}$

The ALP, however, had not only begun to reverse its uranium mining policy after 1982, allowing the operation of three mines, but also gave the nuclear disarmament movement few concessions. Once the party formed government, an Ambassador for Disarmament was appointed, but this appeared to have little consequence. The government also took part in the South Pacific Forum negotiations for a regional nuclear free zone treaty, but never questioned the entry of US nuclear-armed and nuclear-powered warships into Australian waters and ports. The New Zealand government, meanwhile, effectively banned these ships from 1984. Consultations between the government and peace groups only began in $1985 .{ }^{15}$

Childs' speech acknowledged that the NDP had challenged the leadership of the ALP. Even before then, in 1984, more radically-minded networks of activists were emerging within the movement. PND's existing leadership isolated them. Previously, individual members could vote at all PND general meetings, and local groups and other affiliates could send delegations of up to five or ten members. By 1983 these meetings were being held every couple of months or so, and 200 or more people were attending each one. Changes were put to the August 1984 annual general meeting: except for annual general meetings, individual PND members could not vote and affiliates' delegations would be just two members. With the backing of many ALP and CPA supporters and the more politically conservative representatives of some local groups, these changes were adopted. Attendance at general meetings was immediately fell by half - and did not 
recover when members' voting rights were restored a year later when a constitution was adopted. A CPA activist later observed that PND had steadily declined "since that dreadful AGM in 1984, when the vast majority of the grassroots activists were sent scurrying away and were, on the whole, lost to PND for ever". ${ }^{16}$

\section{Anti-bases campaigning}

At this point, the PND leadership also returned to downplaying anti-bases campaigning, eventually leading to a division within the movement. Originally, PND had stated its main task was "removing $\ldots$ any facility or operation which contributes to preparation for nuclear war", ${ }^{17}$ but most of its planning and publicity for its first Palm Sunday rally raised general peace and nuclear disarmament concerns. It did not resolve that campaigning for withdrawal of foreign military bases had a central role for the movement until later in the year. Then, a discussion of anti-bases campaigning opened up in the PND Newsletter and in the organisation's Executive. Anti-bases demands were also adopted for the following Palm Sunday marches. Yet the demonstrations featured slogans in 1983 and 1984 were "Disarmament Now: East and West" and "Disarm the Nuclear Powers" respectively. At this time, most anti-bases campaigners, backed by a large majority in PND, wanted to challenge the "pro-Soviet" parts of the movement. They supported a perspective of parallel unilateral nuclear disarmaments of each bloc, to be effected by independent peace movements. In the face of threats by some, like CICD, to disaffiliate, they also sought to placate those who initially opposed "anti-Soviet" positions, but the latter eventually supported these slogans because they were compatible with multilateral disarmament perspectives - unlike opposition to the bases. ${ }^{18}$

Anti-bases campaigners also began attempts to organise. At their initiative, the 1982 PND annual general meeting established a sub-committee to report on possible campaign strategies against the Omega submarine navigation base in Gippsland and rejected postponing mass demonstrations on this until the following year. The sub-committee moved immediately into organising demonstrations in Melbourne for October and at the base a month later: the latter would attempt to "occupy" the site. However, the PND executive supported only the Melbourne demonstration, and the sub-committee polarised in the debate on the occupation until the occupation's supporters, primarily university students, were left isolated there. ${ }^{19}$

After the 1983 Palm Sunday march, PND adopted a program of action mainly because this had been proposed by Camilleri. This stated opposition to the bases would be a focal point of campaigns, but the demand it proposed to raise immediately was to stop the visits of nuclear powered or armed warships and planes. Also, its key campaign, a Disarmament Declaration, called for the bases both not to be expanded and to be removed. These contradictions reflected differences, and changing alliances, among the leading groups in PND. One of these included academics and movement workers such as Peter Christoff, Belinda Probert, Richard Tanter and John Wiseman. It emphasised the campaign against the bases, and in general considered the movement to be counterposed to, if also a pressure on, the government. Another group was associated with church-related organisations and the left of the ALP and had Camilleri as its leading representative. (For much of this period, until Camilleri's resignation from the ALP in 1986, he was a member of the ALP Foreign Affairs Committee.) He argued that the anti-bases campaign was the "single most effective way" to work for nuclear disarmament, but because that campaign would not be easily won, the demands against warships and planes should be pushed immediately. A third group was organised primarily through CICD, which in a 1983 position called for a demand for the "non-expansion" of the bases. It appears to have followed the approach proposed by Phil Hind (who was one of the Communist Party members who would shortly leave to form the Socialist Forum group in the ALP), which was to campaign for intermediate positions, such as non-expansion of the bases, the removal of one base, or an inquiry 
into the bases directed at achieving a non-nuclear alliance, in order to gauge support. The combination of the first two had brought about PND's position on the bases. But for the Declaration to be a national campaign, which Camilleri wanted, agreement was needed with groups interstate which had positions similar to CICD. In effect, these two groups came together through their common views that ALP policy was in some way "confused" about the alliance with the US and its bases - for example, that the party and the Hawke government had differences about this - or even that it had reservations about aspects of the alliance, such as the North West Cape submarine communication base. ${ }^{20}$

By August 1983, according to the activist Ken Mansell, mobilisation against the bases had become a side issue for PND. This perhaps overstated the case. PND was organising, as Camilleri had also proposed in April, a demonstration at the Watsonia army barracks in suburban Melbourne. The movement had now found out that this was the site of a satellite communications dish, operated by the Australian military's Defence Signals Directorate, that transmitted submarine target location information to the US Navy. Up to 5000 people rallied there in October 1983 - the largest action that PND ever organised other than the Palm Sunday marches - in a precursor to further developments in anti-bases campaigning. Nonetheless, at this time women's groups carried the weight nationally of public actions against the nuclear war fighting bases in Australia. They organised two peace camps, the first at the Pine Gap electronic surveillance base, near Alice Springs, in 1983, and the second at Cockburn Sound, a naval base in WA, in December 1984. According to Tanter, PND refused to give the Pine Gap camp financial support, because it "couldn't be controlled by PND". ${ }^{21}$

In 1984, however, the nuclear disarmament movement was insurgent and thus difficult for its existing leadership to control. The number of people taking part in the Palm Sunday marches soared, especially outside of Melbourne. A telegram from the foreign minister, which effectively claimed that the demonstrations supported the ALP government's policies, was jeered, at least in Sydney. In Melbourne in June, a PND general meeting adopted action proposals including: a demonstration the following month outside the city's ALP office, on the first day of the party's national conference; a Hiroshima Day demonstration with the theme of oppositions to the US bases and alliance and to uranium mining; and a peace camp to be held at the Watsonia base before the end of the year. ${ }^{22}$ The PND Council, which had replaced the Executive as PND's elected leadership, refused to implement these proposals. In a circular it stated its support for some other activities - none of which were demonstrations, except the blockade of the Roxby Downs uranium mine in South Australia - and "reform of PND structures" (discussed above) on the basis that "we need to work together in the building of a broad coalition actively campaigning for nuclear disarmament". ${ }^{23}$

The Watsonia Peace Camp Organising Collective, however, again won support for their action and recognition of it "as a means of launching" a more general anti-bases campaign at PND's annual general meeting in August (many supporters of the Council had left this meeting after the Council's proposed structural reforms were adopted and a new Council was elected). ${ }^{24}$ Its publicity material highlighted the "first strike" capability of Watsonia and the US bases in Australia, calling them a "nuclear threat" rather than, as the movement had previously done, a nuclear target..$^{25}$ The camp, which included a number of rallies and theme days, ran over two weeks from October into early November. It involved both ongoing and new anti-bases activists, many of the latter coming from the Northcote PND local group, Young People for Nuclear Disarmament (YPND), and Socialist Workers Party members, who now "really did get involved in all phases" of an anti-nuclear action. ${ }^{26}$ The peace camp's effects should not be exaggerated: its largest rally was only up to 1500 -strong. Nonetheless, its successes boosted the confidence of antibases activists, who increasingly saw themselves working outside the framework of PND: in Mansell's view, this was "a turning point". ${ }^{27}$ 
In the new year, Northcote PND activists won approval for a Pine Gap campaign group. Oddly, the key report to its first meeting, in May, was given by Phil Hind, whose anti-bases strategy was at variance with that of the Watsonia activists who formed the basis of this new campaign group. The group needed another meeting, a month later, before it adopted the demand to close Pine Gap, rather than renew its lease, when that expired in 1987: at the same time, it decided to support a YPND initiated action on the Friday evening following Hiroshima Day with this demand and to take that demand to the upcoming National Disarmament Conference. In July, PND Council decided to support an ostensibly radical ("Stop the City") Hiroshima Day "protest against the arms race, unemployment and exploitation". ${ }^{28}$ Again, at the national conference, which began on 29 August 1985, the Pine Gap group distributed a paper that argued a Pine Gap campaign should initiate one against all the bases, which, because they were fundamentally for war-fighting, must be closed. The conference recommended, however, that the movement prioritise campaigning against renewal of the lease of the submarine communication base at NW Cape in 1988, rather than a campaign against a renewal of the Pine Gap lease in 1987. ${ }^{29}$

Campaigning about opposition to the bases had become a fault line in PND. PND's organisation of the National Disarmament Conference was decisive in it moving closer to the ACDP. Although PND originally adopted "Close Pine Gap" as a theme for the 1986 Palm Sunday demonstration, planning and Council meetings added a new theme of "arms race / world poverty", which became encapsulated in the sole slogan of the demonstration, "Disarm: Feed the World". Meanwhile, the Pine Gap campaign group started to organise independently as the AntiBases Campaign. By the end of 1986, it helped to initiate the national Australian Anti-Bases Coalition, which became the major organiser of the campaign to rid Australia of the nuclear warfighting bases. Its major successes were protests about Pine Gap in October 1987 and two years later against the Nurrangar base in South Australia. However, this coalition lacked the capacity for broad mobilisation that the previous form of the peace movement had. ${ }^{30}$

\section{The Nuclear Disarmament Party}

The other means by which the insurgent nuclear disarmament movement sharply posed the demand to close nuclear war-fighting bases was the Nuclear Disarmament Party (NDP). The party, officially founded in June 1984, adopted this as one of its three platform planks, together with stopping the passage of nuclear weapons through Australian waters or airspace and the mining and export of uranium. Many people involved in or supportive of the peace and nuclear disarmament movement felt that they had been betrayed by the ALP, which, besides its policy change on uranium mining, supported the Australian alliance with the United States that already involved, among other things, three US bases in Australia, US warship visits and the landing of US military aircraft at Australian bases. ${ }^{31}$ The party's founding figure, Michael Denborough, rejected both a request to join the ALP and the idea of standing as an independent candidate for the Senate. He favoured forming a new party in order to put these issues on the political agenda by taking votes away from the ALP. In the ranks of the movement, the NDP had strong support: the resources of many local groups were mobilised in the party's campaign, and most of those most closely involved with the Watsonia camp were actively involved. Within six months the party established branches across the country, had 10,000 members and won more than 500, 000 votes - nearly seven per cent of the vote nationally - and one Senate seat when an election was held in December $1984 .^{32}$

Much of the movement's leadership, especially in its larger organisations, opposed or did not get involved in the NDP. Denborough explained the party's formation was discussed and agreed to at "house meetings" in Canberra, but when he first sought further support, among movement supporters he knew in Perth, he "came back in disarray". Then, at a meeting in 
Sydney, a week after the party was launched at a public meeting in Canberra, he said the project encountered "tremendous opposition" from established peace groups, the Democrats and proponents of a national green party, until:

A rather large peculiar friend we had stood up and said: "Well, we've had enough talk. Now, why don't we just get on with it?" Something like that. And then three other people stood up and they agreed to do that. And so we then formed a NSW branch. ${ }^{33}$

This opposition persisted: former NDP candidate Peter Garrett was rejected as a speaker at the 1985 Palm Sunday rally in Sydney. He spoke, instead, in Adelaide. In Victoria, PND debated its own electoral intervention, but, in the end, nothing came of this. Among PND's leaders, the group which were most interested in this, including Tanter, had initially rejected the NDP. They became invoved in the party's election campaign, with Tanter becoming the campaign coordinator; however, once Garrett, a well-known musician, and the former ALP senator Jean Melzer, became NDP candidates, substantial impetus was added to the party. Other parts of PND's leadership opposed the NDP: Camilleri, for example, accepted it was a positive development, but criticised its lack of alternative defence and foreign policies, organisation and failure to consult with peace movement organisations (although these were probably unable, because of their ALP and Democrats members, and clearly unlikely, to support the NDP). ${ }^{34}$

The NDP's impact was not limited to an election campaign. It changed the terms of the debate on nuclear disarmament and uranium issues. For the first, and only, time, the Palm Sunday demonstration in Victoria would have no general slogan at all. PND debated three demands - no warships, no bases and no uranium mining - versus two, to the exclusion of opposition to uranium mining; three won. Before the demonstration, a demand was added to stop the testing of a new missile, the MX, in the Tasman Sea. However, the movement also immediately rose to act: not just the "usual suspects" for such protests - YPND held a 13-day vigil at the US Consulate - but PND itself organised a thousand-strong demonstration and the left of the ALP expressed its opposition. Before Palm Sunday, this demand was achieved when the reelected ALP government's support withdraw support for the tests; this became the only clear example of the enactment of a demand of the movement. Meanwhile, the party also began to organise large public meetings and to get involved in other forms of campaigning. ${ }^{35}$

Then, in April 1985, the NDP split. A majority of the active members of the party did not leave, so the party did not collapse; indeed, in the 1987 double dissolution election it again won a Senate seat, in NSW. But Garrett, its popular figurehead, and its Senator, Jo Vallentine, went, and with them gone its support declined and its membership fell even more quickly.

The division in the party was largely debated as organisational issues: one group or another supposedly favouring centralisation, in their own interest, in branches; proscription of members of other parties; membership decision-making by meetings or postal ballots; automatic appointment of former candidates to decision-making bodies; action by parliamentary members independent of the party; and, thus, generally control of decision-making. ${ }^{36}$ Yet the culmination of differences that emerged among party members in the months after the election rather reflected their views about strategy for the NDP. The "fundamentally radical" ${ }^{37}$ character of the party - Denborough, for example, believed the NDP "was a revolt against all the forces of darkness in general, and the inequalities between the rich and the poor" 38 - was not in dispute. Also, on either side some held that the party would tend to be incorporated into some broader politics, since such views were held on either side. What NDP members disagreed about was what to do about their party's radical character and therefore what kind of party they wanted the NDP to be. The splitting group thought radical politics threatened the NDP. According to Vallentine, that would have marginalised the party and made it unsustainable. NDP members who supported 
the party as it had been constituted argued the party's platform, and its sole political requirement for membership of support for that platform, brought it widespread support, including from disillusioned ALP members. According to them, a broader platform and stricter membership provisions would threaten that support and reflected the impact of pressure on the NDP to be "respectable". ${ }^{39}$

\section{Conclusion}

The nuclear disarmament movement in the 1980s is suggestive of a link between the antiVietnam War movement and the movement against war in Iraq in 2002-2003. On the one hand, the broad capacity for social movement mobilisation rises; on the other hand, the ability of a social movement to persistently oppose the government of the day declines.

In the 1980s movement, which in contrast to the other two movements primarily faced the ALP in government, those who supported and sought opportunities for nuclear disarmament action through the ALP responded to the insurgent movement by isolating the movement's more radical activists. Practical campaigning on some key movement demands was contentious: first with regard to uranium mining, and then in opposition to the nuclear war-fighting bases. As the threat to the opportunist leadership of the movement emerged, they in effect divided the movement, keeping the greater part of the movement under their direction, and then demobilised that. The social movement mobilisation that was left in the hands of the radical activists proved to be too limited to sustain the movement. All of this began to play out in 1984 and 1985, and the decline of movement started then, to a substantial extent even before the heat went out of the Cold War (after Mikhail Gorbachev became the Soviet Union's leader) and certainly before the collapse of Communism in 1989-91.

The 1980s movement is distinguished, however, by the emergence from it of a party which won relatively broad electoral support - at a level, for politics to the left of the ALP, that was not surpassed until more than a quarter-century later, when an ALP government had again been elected. Some argue that the NDP hindered the development of a green party through competition, ${ }^{40}$ or its experience "made environmentalists wary of ... the problems of transforming a social movement into a vehicle for parliamentary politics". ${ }^{41}$ These arguments ignore the impact of the political differences among potential supporters of a green party nationally, which prevented this development in the middle of the 1980s. This included a decision not to try to form a green party at a Canberra meeting in July 1984, when the NDP's impact was identified as a reason but was, in fact, unproven. Meanwhile, the Sydney Greens were founded in August 1984: that party's registration of the Greens name was partly an optimistic response to the NDP and it supported the NDP. ${ }^{42}$ Arguably the NDP's successes also inspired the whole range of new party projects that came in the years that followed, including what has become the Australian Greens. The NDP in its first months stood as an example of what a new party could achieve; first of all it was an opportunity seized. If this opportunity was then squandered, this involved the same problem encountered in the 1980s nuclear disarmament movement as a whole: conflict between those who sought opportunities within the political system as it was, and those who thought they could and had to build political support anew for what they want.

Jonathan Strauss writes and occasionally teaches in politics and history in Cairns after completing his thesis on the Accord and the politics of workers in 2011 at James Cook University. His ongoing research concerns workers' political consciousness, including the roles of social and labour movement participation, issues related to the formation of new worker parties and insights offered by Gramsci's work. 


\section{Endnotes}

* This paper is largely based on research conducted for two theses, supervised variously by Doug Hunt and Andrew Milner. My thanks to them for their assistance, and also to the interviewees. Archival research with regard to People for Nuclear Disarmament (PND) in Victoria was conducted in 1986. The papers referred to were then held in working files by the groups as cited: the Hawthorn People for Nuclear Disarmament (a local group affiiliated to PND) papers were maintained by the author, to which he added papers provided by Steve Wright. The author has not been able at this time to ascertain the archive details for these papers, except where these have remained in the author's possession (as indicated), but the following holdings can be noted: Papers created by Ken Mansell, State Library of Victoria, Libraries Australia ID 13692499; Records of thePeople for Nuclear Disarmament, 1981-92, National Library of Australia MS Acc GB 1994/1406, Libraries Australia ID 13723392. The former is likely to hold the Anti-Bases Campaign documents, the latter PND records, and either might have papers that were held by Hawthorn People for Nuclear Disarmament.

${ }^{1}$ Lawrence S Wittner, "Nuclear Disarmament Activism in Asia and the Pacific, 1971-1996," The Asia-Pacific Journal 25, no. 5 .

${ }^{2}$ Jackie Bornstein and Margot Prior, "A History of 'Psychologists for Peace' in Australia" in Peace Psychology in Australia, ed. Diane Bretherton and Nikola Balvin (London: Springer, 2012), 74.

${ }^{3}$ Verity Burgmann referred to removal of the bases as "the most publicised objective of the anti-nuclear movement", but this does not show that the removal of the bases was the movement's focus: Verity Burgmann, Power and Protest: Movements for Change in Australian Society (Sydney: Allen \& Unwin, 1993), 203.

${ }^{4}$ Malcolm Saunders and Ralph Summy, The Australian Peace Movement: A Short History (Canberra: Peace Research Centre, 1986), 45-46; James Walter, What Were they Thinking: The Politics of Ideas in Australia (Sydney: UNSW Press, 2010), pp. 276-77; Wittner, "Nuclear Disarmament Activism in Asia and the Pacific."

${ }^{5}$ Brendan Carins, "Stop the Drop," in Staining the Wattle: A People's History of Australia since 1788, ed. Verity Burgmann and Jenny Lee (Melbourne: McPhee Gribble/Penguin, 1988), 244, 250-251.

${ }^{6}$ Dennis Altman, cited in ibid., 250.

${ }^{7}$ Peter Annear, "Prospects for the Peace Movement," Direct Action, 18 September 1985, 11; Carins, "Stop the Drop," 243, 245; Saunders and Summy, Australian Peace Movement, 49; Richard Tanter, interview with author, 1986.

${ }^{8}$ The second Cold War arose when the 1970s "détente" between the Soviet Union and the United States ended and was replaced by a higher degree of confrontation between them. It was typified by the foreign and military policies of the US presidency of Ronald Reagan. Prominent parts of those policies included discussion of "first strike" nuclear war options and persistence with a program to deploy land-based "medium range" (and short flight time) nuclear-armed rockets in Western Europe.

${ }_{9}^{9}$ Joseph Camilleri, interview with author, 1986; _-_, "The Legacy of Hiroshima," Pax Christi 5, no. 5 (September-October 1980); Jim Falk, "The Nuclear Bonds," Australian Society 2, no. 11 (December 1983): 20, 23; Herb Feith, "Towards a New Peace Movement," Pax Christi 5, no. 2 (March-April 1980); Alan Roberts, "Preparing to Fight a Nuclear War," Arena, no. 57 (1981); Keith Suter, "Prospects for Peace," Pax Christi 5, no. 5 (September-October 1980); Tanter, interview.

${ }^{10}$ Camilleri, interview; Ken Mansell, interview with author, 1986; Tanter, interview.

${ }^{11}$ These and subsequent quantitative estimates provided are based on the author's protest events survey of all issues of the newspaper Direct Action from 1980 to 1990, supplemented by reference to some issues of Tribune from the same period. A description of the method used for this survey is provided in Jonathan Strauss, "The Accord and Working-Class Consciousness: The Politics of Workers under the Hawke and Keating Governments, 1983-1996" (PhD diss., James Cook University, 2011), 205-10, 354-56.

${ }^{12}$ John Andrews, "The Physicians Movement for the Prevention of Nuclear War," Peace Studies, no. 3 (May 1984): 7; Michelle Braid and Philipa Rothfield, "Women's Action for Peace," Arena, no. 66 (1984); Carins, "Stop the Drop," 245; Shirley Cass, "How I Turned my Nuclear Dread into Rational Fear," Australian Society 2, no. 1 (February 1983): 30-31; Jan Everitt, "Peace Directory," Peace Studies (April 1985): 16-19; Falk, "The 
Nuclear Bonds," 24; Sonya Franks and Louise Denoon, "National Peace Party," Direct Action, 5 June 1985, 26; Suellen Murray, "'Make Pies Not War': Protests by the Women's Peace Movement of the mid-1980s," Australian Historical Studies (2006), 81-94; Jean Nickels, "How to Start a Community Peace Group," Peace Studies (June 1985): 22-23; n.a., "Disarming Lawyers," Australian Society (June 1986): 7; -_-, "Workplace Group Formed," Direct Action, 24 August 1983, 15; People for Nuclear Disarmament, Annual General Meeting, 24 July 1983, Minutes, People for Nuclear Disarmament, Melbourne; _-_, Annual General Meeting, 15 September 1985, Minutes, People for Nuclear Disarmament, Melbourne.

${ }^{13}$ Carins, "Stop the Drop," 244-45; J.S. Western, et al, The Class Structure of Australia, 1986 [computer file], 1986, Australian Social Science Data Archive, The Australian National University, Canberra. The survey was made available through the Australian Social Science Data Archive by the original depositors. Those who carried out the original analysis and collection of the data bear no responsibility for the further analysis and interpretation herein.

${ }^{14}$ Brian Jones, "Labor Ranks Support NZ Nuclear Stand," Direct Action, 20 February 1985, 2,

${ }^{15}$ Carins, "Stop the Drop," 249-50; Timothy Doyle, Green Power: The Environment Movement in Australia (Sydney: UNSW Press, 2000), 160; Jim Green, "Australia's Anti-nuclear Movement: A Short History," Green Left Weekly, 26 August 1998, http://www.greenleft.org.au/node/16973.

${ }^{16}$ Sheril Berkovitch, "What's Happening to PND? What's Happening to the Peace Movement in Victoria? A Report on the Last Year," Lines Newsletter, Special Pre-Conference Issue (September 1986): 21. Also: Sue Bull, interview with author, 1986; Camilleri, interview; Mansell, interview; People for Nuclear Disarmament, Annual General Meeting, 12 August 1984, Minutes, People for Nuclear Disarmament, Melbourne; Annual General Meeting, 15 September 1985, Minutes; Tanter, interview. Camilleri argued, however, that the effects of the AGM were "swept aside" by the subsequent course of event: Camilleri, interview.

${ }^{17}$ People for Nuclear Disarmament, "Statement of Aims," PND Newsletter, no. 1 (December 1981).

${ }^{18}$ Camilleri, interview; Mansell, interview; People for Nuclear Disarmament, Rally and Festival Planning Meeting, 9/12/81, Minutes, 9 December 1981, People for Nuclear Disarmament, Melbourne; Andrew Milner, "From Russia with Love or You Only Live Once" (Melbourne: Hawthorn People for Nuclear Disarmament, 1982), 1; People for Nuclear Disarmament, April 4 Media Kit (Melbourne: People for Nuclear Disarmament, 1982); _-_, "Nuclear Disarmament, the Only Alternative," ed. People for Nuclear Disarmament (Melbourne, 1982); _-_, Annual General Meeting, 4 July 1982, Minutes, People for Nuclear Disarmament, Melbourne; - - - "Disarmament Now: East and West ", ed. People for Nuclear Disarmament (Melbourne1983); _-_, "Disarm the Nuclear Powers," ed. People for Nuclear Disarmament (Melbourne1984); Tanter, interview.

${ }^{19}$ Ken Mansell, "Reflections on the Anti-Bases Campaign", 1982, in author's possession; Annual General Meeting, 4 July 1982, Minutes; People for Nuclear Disarmament, Executive Meeting, 22 September 1982, Minutes, People for Nuclear Disarmament, Melbourne.

${ }^{20}$ Australian Council for Disarmament and Peace, "Disarmament Declaration," ed. Australian Council for Disarmament and Peace (Melbourne1983); Camilleri, interview; _-_, The Australian Nuclear

Disarmament Movement - A Strategy for the Next Twelve Months, 1983, in author's possession; - - "Labour's Disarmament Policy," Arena, no. 64: 43-44; People for Nuclear Disarmament, General Meeting, 30 April 1983, Minutes, People for Nuclear Disarmament, Melbourne; Tanter, interview; "ANZUS and World Peace," Tribune, 23 June 1982.

${ }^{21}$ Bull, interview; Burgmann, Power and Protest, 204; Ken Mansell, "Notes from the Rearguard," First Strike, no. 3 (August 1983); Murray, "Make Pies Not War."; Tanter, interview.

${ }^{22}$ Peter Anderson, "Marches Mark Deepening Antiwar Sentiment," Direct Action, 2 May 1984, 12; People for Nuclear Disarmament, General Meeting, 2 June 1984, Minutes, People for Nuclear Disarmament, Melbourne.

${ }^{23}$ People for Nuclear Disarmament Council, Letter, 26 June 1984, Hawthorn People for Nuclear

Disarmament, Melbourne. Emphasis in original.

${ }^{24}$ Bull, interview; Annual General Meeting, 12 August 1984, Minutes.

${ }^{25}$ People for Nuclear Disarmament, "What's at Watsonia," ed. People for Nuclear Disarmament (Melbourne1984); Research Group of the Watsonia Peace Camp Organising Collective, "The Watsonia 
Network and Preparations for Nuclear War," ed. Watsonia Peace Camp Organising Collective (Melbourne1984).

${ }^{26}$ Bull, interview.

${ }^{27}$ Mansell, interview.

${ }^{28}$ Bull, interview; Hiroshima Day Committee, "Hiroshima Never Again," ed. Hiroshima Day Committee (Melbourne: Hiroshima Day Committee, 1985); People for Nuclear Disarmament, General Meeting, 24 February 1985, Minutes, People for Nuclear Disarmament, Melbourne; -_-, Council Meeting, 10 July 1985, Minutes, People for Nuclear Disarmament, Melbourne; - - - "Hiroshima Day: Stop the City," ed. People for Nuclear Disarmament (Melbourne: People for Nuclear Disarmament, 1985); Pine Gap Campaign, Minutes, 11 June 1985, Anti-Bases Campaign, Melbourne; - - , Minutes, 13 May 1985, AntiBases Campaign, Melbourne.

${ }^{29}$ Joseph Camilleri, "Charting a Course", 1985, Hawthorn People for Nuclear Disarmament, Melbourne, 46; Carins, "Stop the Drop," 252; Ken Mansell, "Nic Witte, and Monika Allen, Pine Gap: On the Agenda", Anti-Bases Campaign, Melbourne, 1985, 1, 5-7.

${ }^{30}$ Ian Cohen claims that Sydney's "Peace Squadron revitalised the anti-nuclear movement in Australia, after the defeat at Roxby Downs" of a 1984 anti-uranium mining blockade: Ian Cohen, Green Fire (Sydney: Harper Collins, 1996), 148. But the peace movement's largest actions followed the Roxby defeat, while the Peace Squadron at most played a role in Sydney like that played nationally by the anti-bases campaign. ${ }^{31}$ Compare with Tom Bramble and Rick Kuhn, who, in discussing the February 1985 defeat of the government's plan to aid US missile testing off the Australian coast, claimed the testing was "in clear defiance of the Party's anti-nuclear policy": Tom Bramble and Rick Kuhn, Labor's Conflict: Big Business, Workers and the Politics of Class (Melbourne: Cambridge University Press, 2011), 121. Bramble and Kuhn also attributed that defeat to the ALP Left, with cross-factional support. In this, they at first fail to mention the NDP and its 1984 election campaigns, and when they do, they downplay the influence of the NDP by stating it "fell apart ... quickly" after the elections: ibid., 121-22. In February 1985, the NDP had not split and was, in fact, still growing.

${ }^{32}$ Peter Annear, "The NDP Split: What Really Happened?," Direct Action, 8 May 1985, 10; Bull, interview; Carins, "Stop the Drop," 251-52; Peter Christoff, "The Nuclear Disarmament Party," Arena, no. 70 (1985): 14; Mansell, interview; Jo Vallentine, "A Green Peace: Beyond Disarmament," in Green Politics in Australia, ed. Drew Hutton (Sydney: Angus \& Robertson, 1987), 55-56; Patrick White, "In This World of Hypocrisy and Cynicism," Arena, no. 68 (1984): 13; C. Wilcox, "The Most Important Issue," The Newsletter, no. 1: 5. ${ }^{33}$ Michael Denborough, interview with author.

${ }^{34}$ Bull, interview; Camilleri, interview; Gillian Fisher, Half-Life: The NDP: Peace, Protest and Party Politics (Sydney: State Library of New South Wales Press, 1995), 5, 54; Tanter, interview.

${ }^{35}$ Denborough, interview; R. Eason, "The Peace Movement, the ALP and MX," Flashpoint 2, no. 1 (April 1985): 6-7; Fisher, Half-Life, 52-54; Bill Mason, "Protests in several cities follow MX furore," Direct Action, 20 February 1985, 19; Charles Parker, "Garrett: Nuclearism a Disease," Direct Action, 20 March 1985, 19; People for Nuclear Disarmament, "Disarmament Rally," ed. People for Nuclear Disarmament (Melbourne1985); _-_, General Meeting, 18 November 1984, Minutes, People for Nuclear Disarmament, Melbourne.

${ }^{36}$ Annear, "The NDP Split: What Really Happened?," 10; Ian Cameron, “The NDP: What Went Wrong”, May 1985, cited in Fisher, Half-Life; ibid., 34, 58-62, 68-71; Denborough, interview.

${ }^{37}$ Jo Vallentine, "The Greening of the Peace Movement in Australia," National Outlook (September-October 1989): 9.

${ }^{38}$ Denborough, interview.

${ }^{39}$ Frances Collins, "We're Going out and Getting Branches Established," Direct Action, no. 521 (8 May): 1415; Denborough, interview; Ramani De Silva, "NDP Prepares for the Future," Direct Action, no. 515 (13 March): 9; Fisher, Half-Life, xii, 5-7, 10, 43, 85-86; Nuclear Disarmament Party National Constitution (June 1984), reprinted as Appendix A in ibid., p. 137; M. Hockings, C. Wilcox and M. Perrott, "What Next for the Nuclear Disarmament Party," The Newsletter, no. 1 (May 1985): 17; James Norman, Bob Brown: Gentle Revolutionary (Sydney: Allen \& Unwin, 2004), 164; Jim Percy, The ALP, the Nuclear Disarmament Party and the Elections (Sydney: Pathfinder Press (Australia), 1984), 24-25, 28; Sian Prior, "The Rise and Fall of 
the Nuclear Disarmament Party," Social Alternatives 6, no. 4 (November 1987): 7; Marian Quigley, "The Rise and Fall(?) of the Nuclear Disarmament Party," Current Affairs Bulletin 62, no. 11 (April 1986): 15; Vallentine, "The Greening of the Peace Movement," 8-9.

${ }^{40}$ Timothy Doyle and Aynsley Kellow, Environmental Politics and Policy Making in Australia (Melbourne: Macmillan, 1995), 130; Fisher, Half-Life, 5-6.

${ }^{41}$ Elim Papadakis, Politics and the Environment (Sydney: Allen \& Unwin, 1993), 180.

${ }^{42}$ Fisher, Half-Life, 5, 77-78; Tony Harris, "Regulating the Greens: Federal Electoral Laws and the Emergence of Green Parties in the 1980s and 1990s," Labour History, no. 99 (November 2010): 72. 
Michael Hamel-Green, "Antinuclear Campaigning and the South Pacific Nuclear-Free Zone (Rarotonga) Treaty, 1960-85", Proceedings of the 14th Biennial Labour History Conference, eds, Phillip Deery and Julie Kimber (Melbourne: Australian Society for the Study of Labour History, 2015), 51-62. ISBN: 978-09803883-3-6.

\section{Antinuclear Campaigning and the South Pacific Nuclear-Free Zone (Rarotonga) Treaty,} 1960-85

\section{Michael Hamel-Green}

Previous histories of the disarmament movement have given relatively little attention to the sustained role that Australian, New Zealand and Pacific Island anti-nuclear movements played over three decades from 1960 to 1985 in initially proposing the establishment of a Pacific and wider Southern Hemisphere nuclear free zone, lobbying their respective Labor Parties and Labor Governments for changes in party policy, and eventually prompting regional governments to commence the SPNWFZ treaty negotiations that led to the signing of the 1985 Rarotonga Treaty. At the time this was only the second regional NWFZ to be established anywhere in the world. It continues to ban land-based nuclear weapon stationing by any nuclear power and constrains any Australian moves to acquire nuclear weapons. The paper draws on available primary and secondary documentary sources to identify the specific ways in which Australian, New Zealand and Pacific Island antinuclear movements influenced (and in some aspects failed to influence) government policy on regional denuclearization. The paper concludes that while the treaty as finally negotiated contained many weaknesses from the viewpoint of complete nuclear disengagement, particularly in its failure to prevent nuclear ship visits, missile testing, nuclear-weapon-related electronic bases, and reliance on extended nuclear deterrence on the part of Australia, it has achieved some partial advances in legally constraining potential Australian moves to acquire nuclear weapon, reassurance to regional neighbours, prevention of stationing of nuclear weapons by external nuclear weapon states, and encouragement of regional states to participate in a global network of nuclear free zone member states that is acting as an international lobby group to work for the global elimination of nuclear weapons.

Regional nuclear-weapon-free zone (NWFZ) treaties are important strings to the disarmament and non-proliferation bow. They serve to complement the 1968 Non Proliferation Treaty (NPT) and add impetus to more far-reaching efforts to eliminate nuclear weapons globally. Six such zones are now in force across the globe, covering almost all of the Southern Hemisphere and some parts of the Northern Hemisphere: Australia and the South Pacific (1985 Rarotonga Treaty), Latin America (1967 Tlatelolco Treaty), Antarctica (1959), Southeast Asia (1995 Bangkok Treaty), Africa (1996 Pelindaba Treaty), and Central Asia (2006 Semipalatinsk Treaty). ${ }^{1} 112$ out of 194 current UN member states are currently signatories to zones in their region. While NWFZs differ from region to region in their degree of rigour, all aim to prevent regional states from acquiring their own nuclear weapons and to prevent nuclear weapon states (NWS) from stationing nuclear weapons in the zone. They also seek to secure legally binding assurances from the five NPTrecognized nuclear weapon states (US, UK, France, Russia and China) that they will not use or threaten to use nuclear weapons against NWFZ zone states. ${ }^{2}$

This paper examines the role and contribution of antinuclear and civil society efforts to establish a regional nuclear free zone in the period up to the signing of the 1985 South Pacific Nuclear Free Zone (SPNFZ) Rarotonga Treaty, negotiated under the auspices of the South Pacific Forum (now Pacific Islands Forum), the regional organization of independent South Pacific 
island states, Australia and New Zealand. ${ }^{3}$ In the case of the 1985 Rarotonga Treaty, the antinuclear campaigns that led up to and contributed to the negotiation of the treaty began some 25 years earlier and may be divided into three broad waves.

The first wave of pressure from 1960 to 1964 was focused on efforts within both Australia and New Zealand to establish a Southern Hemisphere NWFZ. This was overshadowed from 1965 to 1972 by the advent of the Vietnam War and peace movement concentration on ending that war. The second wave of pressure was from 1973 to 1975 and focused more specifically on establishing a regional South Pacific Nuclear Free Zone in the context of continued French nuclear testing in the region. During this period, the main involvement was on the part of antitesting movements, the New Zealand Labour Party, and the New Zealand, Fijian and Papua New Guinea Governments. The third and ultimately successful wave of pressure was from 1975 to 1985, involving campaigning at the regional level by the transnational Nuclear Free and Independent Pacific Movement, together with national antinuclear campaigns in Fiji, Australia and New Zealand, leading to active support and action from South Pacific Forum member governments, especially from Labour Governments in Australia and New Zealand during 198485.

\section{First Wave: the Southern Hemisphere NFZ Initiative, 1960-64}

The first wave of regional interest and proposals in a nuclear free zone emerged in the late 1950s and early 1960s in the context of increasing international concern and protest over nuclear weapons testing, the risks of radioactive fallout, and the threat posed by nuclear weapons in the context of Cold War tensions. ${ }^{4}$ Concern over nuclear threats was particularly heightened during the 1962 Cuban Missile Crisis when the world came close to the brink of nuclear war.

Australia and Pacific islands were important sites for nuclear testing and potential proliferation in the central Pacific where the US began testing nuclear weapons in the Marshall Islands from 1946 onwards, and in Australia where Britain began testing from 1952, later moving to Christmas Island in Kiribati (formerly the British administered Gilbert and Ellis Islands). Despite reassurances from the Menzies Government, public concern began to emerge about radioactive fallout from the British tests, especially after Britain moved its test program to Maralinga in South Australia.

Not only was Australia host to British nuclear testing, but the Menzies Government was negotiating with the United States about the establishment of the 1963 Northwest Cape communication facility for US nuclear-armed submarines. There is also now evidence that the Menzies Government was actively considering nuclear weapon acquisition in the mid 1950s to early 1960s, including holding discussions with the UK on possible transfer of tactical nuclear weapons. ${ }^{5}$ However, after a March 1957 agreement between President Eisenhower and Prime Minister Macmillan on the special UK-US relationship, Australia was excluded from nuclear sharing arrangements

It was in this context that the first proposal for a regional nuclear free zone was advanced in the Australian Parliament on 15 May 1962 by the leader of the Opposition, Arthur Calwell. ${ }^{6}$ Calwell proposed that the 1959 Antarctic Treaty nuclear-free-zone be extended to include the whole Southern Hemisphere, and called for the convening of a conference of both Antarctic treaty members and other countries to discuss the possibility of establishing such a wider NWFZ. Menzies dismissed the proposal on the grounds that Australia should not "permanently contract herself out of permitting nuclear weapons to be used in war or defence...on her soil" and asked, "Have we reached the very ecstasy of suicide in Australia?" Menzies' response reflected the Cold War zero-sum thinking of the time in the context of the prevailing Western containment policy towards communism, and Australian fears of Communist China and concern about communist influence in Indonesia and Malaysia. 
Within the Labor Party, the Southern Hemisphere NWFZ was originally advanced and endorsed at the 5 May 1962 Federal Executive meeting, and reaffirmed at its 5 July 1962 meeting. ${ }^{8}$ The Labor nuclear-free-zone policy did not appear in a vacuum. It emerged and was proposed by the Labor Party leadership in the context of an upsurge in the antinuclear and disarmament movements both internationally and within Australia as fears spread about the radioactive consequences of nuclear testing and the threat to humanity posed by nuclear weapons. Established peace and disarmament organisations, such as the Melbourne-based Congress for International Cooperation and Disarmament (CICD) (and the Sydney-based Association for International Cooperation and Disarmament established (AICD) were joined in the early 1960s by newer groups inspired by the example and success of the British CND and Committee of 100 . They included Campaign for Nuclear Disarmament groups in Melbourne (1960), Sydney (1962), Brisbane (1962) and Perth (1962). ${ }^{9}$ There were parallel developments in New Zealand where, during 1959-1960 various nuclear disarmament groups across the country formed a national New Zealand CND with over 1,700 members. ${ }^{10}$

Both in Australia and New Zealand, the various groups were active in lobbying Opposition Labor Parties and organizing Aldermaston-style radial marches from outer suburbs to central city areas to symbolize the radius of destruction from a nuclear bomb. More specifically, disarmament advocates in both Australia and New Zealand strongly supported Labour leaders on the need to pursue a Southern Hemisphere Nuclear Free Zone.

A key campaigning tool was the organization of national peace petitions. 1962 and 1963 petitions, initiated by the NSW Peace Committee, focused on support for Calwell's May 1962 proposal to extend the Antarctic nuclear-free-zone to cover the whole Southern Hemisphere. The 1962 petition was particularly widely supported across Australia, with over 200,000 signatures. ${ }^{11}$ At Calwell's 1963 election policy speech, CND supporters provided "one of the loudest burst of applause" for the part of his speech on the nuclear free zone". ${ }^{12}$

Across the Tasman, the New Zealand CND and other civil society disarmament activists were successful in encouraging the New Zealand Labour Party to adopt the CND Southern Hemisphere NWFZ proposal as policy in 1964. CND antinuclear advocate, Dr Ron Locker, presented a petition with 80,238 signatures to Parliament in 1963 calling for the Southern Hemisphere to be nuclear-weapon-free zone. ${ }^{13}$ Clements notes that "The idea of a nuclear weapons-free zone appeared a good year before it became Labour Party policy". ${ }^{14}$ In both Australia and New Zealand, the antinuclear movements in this period placed great emphasis not only on petitions and marches but also on seeking to have the opposition Labo(u)r parties in both countries adopt nuclear free zone policies that might be pursued were the parties to come to power, as indeed happened in 1972.

\section{Second Wave: The UN SPNFZ Resolution, 1965-1975}

While the focus of the peace movements in both Australia and New Zealand during the late 1950s and early to mid 1960s was primarily on nuclear disarmament and testing, the advent of conscription at the end of 1964 and the first Australian troops dispatched to the Vietnam War in April 1965 led to the peace movement refocusing its aims and energies on stopping the Vietnam war and ending conscription. Both in Melbourne and Sydney, the newer nuclear disarmament CND groups transformed themselves into anti-Vietnam war committees. ${ }^{15}$

Despite the understandable concentration of the Australian peace and anti-war movement on a war that was directly involving Australian troops and conscripts, there was also an awareness on the part of antinuclear movements across the South Pacific that nuclear activities and potential threats in the Pacific region were far from diminishing, indeed were increasing in the form of nuclear testing, missile testing, nuclear basing arrangements, nuclear-armed ship visits occurring widely in both the South and North Pacific regions, and the mining of uranium in 
Australia. ${ }^{16}$ The most serious of potential new nuclear threats as perceived regionally was the decision of France to commence nuclear testing in the Pacific. In January 1963, the French President, Charles de Gaulle, announced the establishment of a nuclear testing base at Moruroa and Fangataufa in Polynesia. ${ }^{17}$ Between 1966 and 1974, France was to conduct 46 atmospheric tests at the base, including an $\mathrm{H}$-bomb test in $1968 .{ }^{18}$

Elsewhere in the Pacific, the US was continuing its missile testing at Kwajalein Atoll in the Marshall Islands, and undertaking nuclear ship visits to many ports in the Pacific while refusing to confirm the presence of nuclear weapons under its "non-confirm, non-deny" policy. Within Australia and New Zealand, the US also established electronic communication, command, control, and intelligence (C3I) bases with potential or actual roles in relation to US nuclear armed forces, including submarines. In Australia, it established the Northwest Cape base in Western Australia in 1963 with bipartisan support from the Government and the Opposition Labor Party, although the latter was greatly divided on the base agreement, with left leaders of the party strongly opposing it. Further US C31 installations followed at Pine Gap and Nurrungar. ${ }^{19}$

During this 1965-1976 period, antinuclear movements across the Pacific began to spring up and actively campaign on nuclear related issues, particularly after French nuclear testing at Mororua began in 1966, with consequent radioactive fallout across the whole Southern Pacific.

In New Zealand, David Lange recalled that "public concern about (French testing's) harmful effect was widespread" and that after coming to office in 1972, the Kirk Labour Government responded to public concern by sending two frigates into the test zone in July 1973, and worked together with the Australian Whitlam Labor Government in mounting a case against French testing in the International Court of Justice. ${ }^{20}$ The Court voted eight to six on 23 June 1973 to call on France to end the testing. ${ }^{21}$ This was partially successful in that France decided to end its atmospheric test program in 1974, but France continued with underground testing at Moruroa and Fangataufa, and went on to conduct a further 147 tests between 1975 and $1996 .{ }^{22}$

Peace and independence movements in other parts of the South Pacific were also beginning to mobilize strongly against nuclear threats, particularly French nuclear testing. As early as 1970, a Fijian anti-nuclear movement had emerged in the form of ATOM (Against Tests on Moruroa), established by concerned members of the Pacific Theological College, University of the South Pacific, Student Christian Movement, YWCA, Fiji Council of Churches, and University of the South Pacific Students Association. ${ }^{23}$ The group researched and publicized the likely effects of the French tests, and met with the Fijian Prime Minister, Ratu Sir Kamisese Mara, to pursue their concerns ${ }^{24}$ Significantly, one of the first acts of the new South Pacific Forum regional organization was its 1971 call for an end to French nuclear testing in the Pacific. ${ }^{25}$ In Polynesia itself, there was widespread opposition to the French testing program both within the territorial assembly and on the part of anti-nuclear and independence activists. Continued protest over the impacts of the tests intensified in 1973 with international antinuclear groups, such as Greenpeace, staging sail-ins that attracted world wide attention to the tests. ${ }^{26}$

It was in this wider regional context of concern and protest over both nuclear testing and wider nuclear activities in the region that the 1972-75 Kirk (later Rowlings) New Zealand Government began initiating a new regional diplomatic campaign to establish a South Pacific nuclear weapon free zone. This campaign not only reflected the immediate regional concerns over French nuclear testing and domestic New Zealand concerns over US military installations in New Zealand, but also served to deliver on the Kirk Government's commitment in its 1972 Labour Party Election Manifesto to call for the convening of a regional Pacific conference to establish a nuclear weapon and test-free zone along the lines of the Antarctic Treaty. This 1972 election promise was a direct policy continuation of the earlier Southern Hemisphere NWFZ policy that was originally advanced in the Party's 1963 Conference Report and Election Manifesto, and reaffirmed with minor modifications in the Party's 1966 Conference Report and 1969 Election 
Manifesto, all of which may be considered a response to the energetic lobbying and petitioning of the New Zealand antinuclear movement. ${ }^{27}$

The Kirk Labour Government's 1975 nuclear-free-zone proposal called for a South Pacific Nuclear Free Zone extending from 60 degrees South (the Antarctic Treaty boundary) to the Equator, with the eastern and western boundaries to be negotiated. ${ }^{28}$ The Kirk Government's pursuit of the treaty even after the cessation of French atmospheric testing in 1974 reflected wider concerns about intrusion of superpower rivalry into the South Pacific and continuing nuclearrelated activities in the region, including US military installations in New Zealand.

The first step of the New Zealand Kirk Government was to take the proposal to the mid1974 ANZUS Council Meeting with Australia and the US, but immediately met with opposition from the US Secretary of State, who refused to let it be included in the ANZUS final communiqué. ${ }^{29}$ Undeterred, the Kirk Government took the SPNFZ proposal to the July 1975 South Pacific Forum, where it was supported by all the Forum island states and Australia (still under the Whitlam Labor Government). The Forum "emphasised the importance of keeping the region free from the risk of nuclear contamination and involvement in a nuclear conflict" and "commended the idea of establishing an nuclear weapons free zone in the South Pacific as a means of achieving that aim". ${ }^{30}$ Despite continued US opposition, New Zealand Kirk Government, joined by Fiji and Papua New Guinea, continued its efforts to secure support for the zone by taking the proposal to the UN General Assembly. The joint UN General Assembly resolution on 11 December 1975 endorsed establishment of a South Pacific nuclear-free-zone and enjoined all the countries concerned to carry forward consultations about ways and means of implementing the proposal. The motion was carried 110 votes to 0 , with 20 abstentions (abstainers include four nuclear weapon states, US, USSR, UK and France). ${ }^{31}$

With the advent of the Fraser Liberal-County Party Coalition Government in Australia and the Muldoon National Party Government in New Zealand in late 1975, the consultations called for in the UN resolution on the SPNFZ were not pursued. As David Lange noted, "The [New Zealand] National Government, knowing America's wishes, had buried the zone. That to me was a denial of the right of the people of the South Pacific to decide their own destiny." ${ }^{32}$

While overshadowed by campaigns to end the Vietnam war, this second wave of antinuclear movement efforts to secure a SPNFZ did involve some important advances in successfully securing Labo(u)r opposition parties' support for a SPNFZ, the subsequent active support and advocacy of the New Zealand, Fiji and PNG governments, and finally international backing for the idea at the UN on the part of the great majority of UN member states.

\section{Third Wave: the Nuclear-Free Pacific Campaign and Rarotonga Treaty, 1975-1985}

The reluctance to pursue the 1975 SPNFZ proposal on the part of the incoming conservative Australian and New Zealand governments in late 1975 delayed but did not ultimately prevent progress towards implementing the initiative. Anti-nuclear movements across the Pacific region and within Australia and New Zealand continued to press for the zone, finally succeeding in galvanizing the governments of the region to begin negotiating the SPNFZ during 1984-85. These region-wide pressures were prompted by both heightened international awareness of global nuclear threats and regional concerns over continued nuclear activities and threats in the Pacific.

Internationally, there was a reinvigoration of UK and European anti-nuclear movements in the late 1970s and early 1980s focussing on Cold War nuclear threats, particularly that posed by intermediate range nuclear-armed missiles stationed in Europe. Within the Pacific Region, there was a corresponding upsurge in antinuclear movement movements during the late 1970s and early 1980s that was not only concerned about global nuclear threats manifest in Europe but also about specific nuclear entanglements and threats occurring in the Pacific region. These included: the continued French nuclear testing program at Moruroa and Fangataufa; US nuclear-weapon- 
related C3I bases in Australia and New Zealand; US nuclear-armed ship visits to ports in the region; US missile testing in the Pacific; uranium mining in Australia; and the nuclear war implications of the ANZUS Alliance.

One of the most important of the 1975 initiatives relating to the SPNFZ Rarotonga Treaty was the first transnational regional civil society conference to pursue the goal of a regional nuclear free and independent Pacific. The conference, held in Suva from 1-6 April 1975, was initiated by the Fijian antinuclear group, ATOM, and brought together 88 delegates from antinuclear and independence groups across the Pacific, including CND New Zealand, Campaign Against Foreign Military Activities in New Zealand (CAFMANZ), South Pacific Action Network (SPAN), Congress for International Cooperation and Disarmament (CICD) Australia, Les Francais Contre Le Bombe (French) and the Student Christian Movements of Fiji, Australia and New Zealand. ${ }^{33}$

A key outcome of the conference was the drafting of a "People's Treaty for a Nuclear-Free Pacific Zone" which embodied regional anger and opposition to nuclear intrusions and exploitation of the region and advanced a set of denuclearization and decolonization goals for a newly constituted movement, the Nuclear Free Pacific and Independence (NFIP). Renamed the "People's Charter for a Nuclear-Free and Independent Pacific" at successive NFIP regional conferences, the Charter became a unifying manifesto around which grassroots antinuclear and independence movements cooperated in pressing for a comprehensive nuclear free zone and the recognition of indigenous peoples' rights throughout the Pacific region.

The effectiveness of the new NFIP movement rapidly became a source of concern to US diplomats at the time. The former US Ambassador to Fiji, William Boddie Jr., for example, stated in early 1962, "the US must do everything possible to counter this movement. We must convince our friends in the region that a 'nuclear-free Pacific' could change the balance of power with the Soviets to our disadvantage and thereby endanger world peace". ${ }^{34}$

Despite the resistance of the Australia and New Zealand conservative governments in power from 1975 to 1983 (1984 in New Zealand), the Melanesian island states, Papua New Guinea, Vanuatu and Solomon Islands, continued to actively pursue the regional South Pacific NWFZ as reflected in PNG foreign policy statements, and speeches and statements from other South Pacific leaders. Within Fiji, however, the Government's opposition to nuclear activities was moderated in 1983 when the Prime Minister, Sir Kamisese Mara, reversed his previous opposition to nuclear ship visits, possibly as a result of pressures from the United States. Concerned about this shift in Fijian Government policy, anti-nuclear activists, academics, church leaders and trade unionists formed a new antinuclear group in September 1983, the Fiji Anti-Nuclear Group (FANG) with the aims of lobbying at national, regional and international levels against "activities that contribute to nuclearization of the Pacific" and encouraging "public participation in the discussions surrounding the proposed NFZ Treaty" (the latter relating to Australian Hawke Government's revival of the SPNFZ treaty proposal at the 1983 South Pacific Forum). ${ }^{35}$

Within New Zealand and Australia antinuclear movements during the late 1970s and early 1980s were beginning to mobilize the same level of public support and mass participation as the anti-Vietnam war movement in the early 1970s. In New Zealand, the antinuclear peace movement focused particularly on nuclear ship visits. The Auckland antinuclear activist, George Armstrong, founded the Auckland Peace Squadron in October 1975 as "a creative, affirmative, non-violent action...that could make New Zealand an island of sanity in an ocean of peace". ${ }^{36}$ Its aim was to blockade Auckland and other ports against nuclear ship visits, and did this very dramatically when the US cruiser Long Beach visited in October 1976 with a highly publicized armada of small boats, dinghies and surf board riders which obstructed and delayed the passage of the cruiser. By 1979, the Peace Squadron had been joined by a wide range of New Zealand and international anti-nuclear groups including Friends of the Earth, Greenpeace, CND, and the New Zealand Foundation of Peace Studies, and, from 1980, a coordinating body, Peace Movement 
Aotearoa ${ }^{37}$ In 1981 the New Zealand Nuclear Free Zone Committee was initiated by Larry Ross to promote local nuclear-free-zones across New Zealand, and by 1984 had been successful in having 94 local nuclear-weapon-free zones proclaimed by city, county and borough councils (pp.114-16). ${ }^{38}$ During 1980-1982, the antinuclear movement was able to secure a greater commitment to the nuclear free zone proposal from the New Zealand Labour Party at its 1982 Labour Party Conference, just two years before it returned to power at the 1984 election. As Kevin Clements notes:

At the 1982 Labour Party Conference there was a call both for the active promotion of a nuclear weapons-free zone in the South Pacific and resolutions for the withdrawal of New Zealand from ANZUS. (The Nuclear Free Zone Committee and other groups had lobbied party delegates effectively.)...This meant that from 1982 onwards the aspirations of the Labour Party and the peace movement were virtually identical. This provided an important source of electoral strength to the Labour Party in its build-up to the 1984 election campaign. ${ }^{39}$

In early 1983 David Lange assumed the leadership of the New Zealand Labour Party, and was concerned to respond sympathetically to the nuclear-free groundswell both within and beyond the Labour Party. Lange had already been greatly influenced by the antinuclear movement in the 1970s and early 1980s. While still Opposition Leader in 1983, Lange was quick to voice support for the Australian Government's revival of the South Pacific NWFZ proposal at the August 1983 South Pacific Forum meeting, suggesting that "we will be able to work with our Pacific neighbours to achieve a South Pacific nuclear weapon free zone" and arguing that, while the Australian proposal did not go far enough, it would still be a valuable "first step". ${ }^{40}$ A key initiative on the part of the Labour Opposition and the anti-nuclear movement in mid-1984 was a private member's bill put by Richard Pebble. ${ }^{41}$ The bill sought to ban nuclear ship visits, prohibit the building of nuclear reactors and nuclear waste dumping, and give legal recognition to the 1975 UN General Assembly resolution on the SPNFZ.

When the Labour Party came to power on 26 July 1984, David Lange, now Prime Minister, rapidly moved to put into place the Labour Party's nuclear-free New Zealand principles, declining to accept nuclear-armed warships, a move that immediately resulted in conflict with the US and with elements of the New Zealand military, particularly in relation to how the new policy affected the ANZUS alliance. Lange, however, was not to be convinced by the US and ANZUS ally Australian arguments about the need for extended nuclear deterrence to protect New Zealand:

As far as I was concerned, deterrence in the South Pacific was more than dangerous, it was absurd. Nobody could for a moment imagine that the United States would risk its people, and the world's, by defending its small and distant ally with nuclear weapons. No invader, if there ever was one, would be held back for a moment by such an unlikely possibility. ${ }^{42}$

The Lange Government explicitly renounced reliance on a nuclear defence for New Zealand, even if that posed strains on its ANZUS alliance with the United States. Following New Zealand rejection of a proposed visit by the USS Buchanan in February 1985, the Reagan Administration suspended ANZUS links and security guarantees to New Zealand from August 1986.

The Lange Government followed up its denuclearization initiatives within New Zealand by offering rapid support to the Australian Hawke Government's raising of the SPNFZ proposal the South Pacific Forum. The August 1984 South Pacific Forum meeting took place just one month after the Lange Government came to power, and New Zealand moved to give rapid and 
full support to the Australian proposal. Lange has noted that he went to the 1984 South Pacific Forum "to resurrect the idea of a South Pacific nuclear-free-zone". ${ }^{43}$ From David Lange's point of view, the SPNFZ Treaty as signed at Rarotonga a year later, fell very short of the nuclear disengagement approaches that New Zealand had embarked on within its own territory, but did, however, represent the first rung on a ladder towards more comprehensive regional denuclearization.

During this third 1975-1985 period of regional campaigning to secure a SPNFZ, the antinuclear movement pressures for such a zone were equally strong in Australia. During the early 1980s, the wider Australian antinuclear movement was coordinated through coalition groupings, such as People for Nuclear Disarmament (PND) organizations at the state level and the Australian Coalition for Disarmament and Peace at the national level. PND was initially established in Melbourne in October 1981 and rapidly attracted 50 affiliated groups and organizations, including professional groups, unions, environmental, student, church and women's groups. ${ }^{44}$

The Australian antinuclear movement at this time focused on a range of goals, such as global abolition of nuclear weapons, ending uranium mining, and dismantling US nuclearweapon-related bases in Australia, but also included a call for the creation of a nuclear-free Pacific region. Besides the major Palm Sunday rallies, a major strategy on the part of PND was the Disarmament Declaration Campaign which presented a declaration to the Australian Government in October 1984 that was signed by 250,000 individuals. The Declaration demanded "the removal of American nuclear-related bases from our soil, an end to visits to Australia of any nuclear armed ships or planes, an end to uranium mining, and the creation of a nuclear-free zone in the Pacific region". ${ }^{45}$

A particular development that concentrated the minds of some politicians in the major parties was the success of the newly established Nuclear Disarmament Party which contested the 1984 federal elections, winning $9.7 \%$ of the Senate vote in NSW and $6.9 \%$ of the vote in Victoria, and the election of a senator (Jo Vallentine) in Western Australia.

In August 1963, the new Hawke Labor Government took several steps to respond to the upsurge in Australian, regional and international calls for action on nuclear issues and threats. One was to respond to the calls for a regional nuclear free zone by officially proposing a South Pacific NWFZ at the August 1983 South Pacific Forum meeting, the regional South Pacific island state body that had first endorsed the concept in 1975 as then proposed by New Zealand, Fiji and Papua New Guinea. Others included appointing an Ambassador for Disarmament and establishing a Peace Research Institute at the Australian National University (later to be defunded by the conservative Howard Government).

The Hawke Government continued to pursue the SPNFZ initiative at the August 1984 South Pacific Forum meeting, this time with the added support of the new Lange Labour Government. Out of the 1984 Forum Meeting, the Hawke Government was successful in forming and chairing a working group of Forum states to negotiate an actual treaty. The drafting group met over the ensuing year, and the final draft of South Pacific NWFZ Treaty was opened for signature at the ensuing 1985 South Pacific Forum meeting. ${ }^{46}$

The influence of the anti-nuclear movement in galvanizing the Hawke Government's initiative in advancing and successfully negotiating the SPNFZ Treaty over this period is confirmed in now declassified Cabinet documents relating to decisions on this initiative and in the memoirs and public statements of key players at the time, especially the Australian Foreign Minister, Bill Hayden. Writing in his memoir of the period, Hayden recalled: "At the 1984 election there was so much concern...that a Nuclear Disarmament Party...fielded candidates in the election...I instinctively recognised that we would have to move quickly and decisively to establish our ascendancy on peace and disarmament issues. ${ }^{\prime 47} \mathrm{He}$ continued: 
In the light of the mounting protests...Hawke suddenly reassessed things and I was off and away with a raft of arms control policies. The initiatives and activities included: the appointment of an Ambassador for Disarmament; pressure for the negotiation of an effective comprehensive nuclear test ban treaty; work on a treaty outlawing all forms of chemical biological warfare... condemnation of French nuclear testing in the Pacific; the successful pursuit of a nuclear-free-zone for the South Pacific. ${ }^{48}$

At the same time as responding positively to the upsurge in the peace movement, however, both Prime Minister Hawke and Hayden were concerned that any disarmament initiatives, including the South Pacific nuclear free zone initiative, avoid unnecessary conflict with the US in the context of the ANZUS alliance. Hayden noted in his memoirs that, if the Left sought to "abrogate" the alliance unilaterally following the New Zealand Labour Party's example, this could "produce an unsatisfactory overall political outcome for Labor". ${ }^{49}$

Bob Hawke, for his part, emphasised that his government, "while recommitting Australia to our major defence alliance" was "determined to play a significant part in the cause of peace and disarmament" on the basis that "whatever the strengths of our economic and social programs at home, they would be futile if a nuclear conflagration occurred".${ }^{50}$ In relation to his government's SPNFZ initiative, he noted his determination to go ahead with the initiative despite the opposition of the US Reagan Administration, but that he had explained to the US that the zone did not differ from or go beyond the Tlatelolco Treaty provisions, which the US had already signed and ratified, and emphasised that Australia advanced the initiative with the full support of all the South Pacific regional states. ${ }^{51}$

References to the SPNFZ initiative in 1985 Cabinet-in-Confidence documents, declassified in 2013, indicate an intention to implement the ALP's Platform policy of promoting "the development of zones of peace and nuclear free zones in the Indian and Pacific Oceans". ${ }^{52}$ The documents noted that general support for the initiative could be expected "especially the proposed bans on testing and stationing of nuclear weapons" but that it was anticipated that the treaty would encounter criticism from both sides of politics: "both groups that see it as eroding ANZUS and Australian security interests and groups that feel it does not go far enough". ${ }^{53}$ The progress report for Cabinet prepared by Foreign Minister Bill Hayden argued that the "The conclusion of a SPNFZ would be a significant arms control achievement and one that would strengthen regional security" and that it was "designed to maintain the security advantages afforded to the South West Pacific through the ANZUS Treaty and the United States security presence in the region". ${ }^{54}$

The reference in the Cabinet documents to the ALP Platform policy on a Pacific nuclear free zone bears witness to the influence of antinuclear campaigning in the sense of reflecting the success of lobbying inside and outside the Party by antinuclear groups and advocates. From the late 1970s onwards, there was an increasing emphasis on disarmament policies and positions at ALP Federal Conferences and its policy platforms. Responding in part to the concerns raised by successive Nuclear Free Pacific movement conferences and campaigns, the 1979 Federal ALP Conference adopted a policy of support for a "nuclear free zone proposal in the Southern Pacific area". ${ }^{55}$ This was reaffirmed at the July 1982 Conference a year before the Hawke Government came to power in the form of a Conference resolution stating, inter alia, that "Conference, noting Labor's platform commitment to 'support a nuclear free zone proposal in the Southern Pacific area." ${ }^{56}$ Following the successful negotiation of the SPNFZ treaty and its signature at the Rarotonga South Pacific Forum in 1985, the treaty entered into force on 11 December 1986. Four of the five nuclear weapon states have now signed and ratified all the relevant protocols, while the 
United States signed the protocols in 1996 and is currently considering ratification in legislation before the US Congress.

\section{Conclusion}

The 1985 South Pacific NWFZ Treaty provisions fell well short of what antinuclear movements were seeking at the time and have been seeking since. It does not prevent nuclear-armed ship visits and transit within the region, although it does leave open the possibility of individual countries instituting such bans within their own territorial waters and ports, as indeed New Zealand has instituted from 1984 and has become a bipartisan position of both New Zealand Labour and conservative government. Nor does it ban nuclear-weapon-related C3I bases, a source of particular concern given their potential for becoming nuclear targets and their role in nuclearwar-fighting. Further, the Treaty does not eschew reliance on extended nuclear deterrence in the context of military alliances with nuclear powers, such as Australia's ANZUS alliance with the United States.

Despite these problems, the Rarotonga Treaty has contributed to some significant partial disarmament and antinuclear advances that do go part of the way to responding to the sustained antinuclear campaigning for such a zone from the 1960s to the 1980s. It has served to lock nuclear powers into not testing nuclear weapons anywhere in the test zone, not only on land but also on the high seas. It does prevent land-based nuclear weapon stationing by nuclear powers in the region (something that the NPT does not prevent). Further, it serves to lock Australia more firmly into a legally binding commitment not to develop nuclear weapons itself. At a regional level, the Rarotonga Treaty provides a degree of reassurance to neighbouring Indonesia and other Southeast Asian countries that Australia is not intending to develop nuclear weapons (ten years after the Rarotonga Treaty Indonesia took the lead in negotiating the 1995 Southeast Asian Nuclear Free Zone Bangkok Treaty). Finally, the Rarotonga Treaty membership does serve to bring Australia, New Zealand and Pacific Island countries into a wider network of regional nuclear free zone treaty members that in recent years has become an active lobbying force for global initiatives on disarmament as well as the spread of nuclear free zones into new regions, not least the Middle East.

Contemporary anti-nuclear movements in Australia, New Zealand and the South Pacific were disappointed at the partial scope of the 1985 South Pacific nuclear free zone treaty and its failure to fully disengage the region from involvement and complicity in nuclear threats, regional and global. Yet despite its limited and partial nature, the Rarotonga Treaty remains a positive step forward in a regional context. It may still - by means of the existing nuclear bans that it imposes, the confidence building role that it plays, the future opportunities for strengthening the treaty, and its international lobbying role as a part of an international network of NWFZ member states - justify the 25 years of antinuclear advocacy that contributed to the treaty's negotiation.

The partial success in securing the negotiation of the SPNFZ Treaty remains a testament to the commitment and resilience of the various antinuclear movements in the South Pacific, New Zealand and Australia in their sustained pursuit of this particular antinuclear initiative through many changes in national governments and a constant flux of conflicts and crises in the international environment. It is unlikely that the culminating Hawke, Lange and Pacific Island governments' negotiation of the Rarotonga Treaty would have occurred without the cumulative inputs, agenda-setting, petitions, sustained lobbying of political parties, creative protest actions, and large scale rallies, of the three waves of antinuclear campaigning from the 1960s to the 1980s.

Michael Hamel-Green has published extensively on regional security and regional arms control and disarmament, including a comprehensive study of the South Pacific Nuclear Free Zone Treaty and a brief account of the Nuclear Free and Independent Pacific Movement. His most 
recent work includes studies of regional denuclearization in Northeast Asia and the Middle East, and a forthcoming book chapter on the role of nuclear weapon free zones as multilateral regional initiatives contributing to global disarmament. He his currently working on a negotiation history of the existing six nuclear weapon free zone treaties.

\section{Endnotes}

\footnotetext{
${ }^{1}$ For texts and current signatories of these NWFZ treaties, see UN Office for Disarmament Affairs, Disarmament Treaties Database, accessed 2 February 2015, http://un.org/unoda//treaties.

${ }^{2}$ For overviews of NWFZs, see: Jozef Goldblat, Arms Control: the New Guide to Negotiations and Agreeements (London: Sage Publications and International Peace Research Institute, 2002), 196-219; Michael Hamel-Green, "Peeling the orange: regional paths to a nuclear-weapon-free world," Disarmament Forum, UNIDIR, no.2 (2011): 3-14; Ramesh Thakur, ed., Nuclear-Weapons-Free Zones (London: Macmillan, 1998); Pericles Alves and Daiana Cipollone, eds. Nuclear-Weapon-Free Zones in the $21^{\text {st }}$ Century (New York and Geneva: UNIDIR, 1997).

${ }^{3}$ For detailed analyses of the Rarotonga Treaty, see Michael Hamel-Green, The South Pacific Nuclear Free Zone Treaty: A Critical Assessment (Canberra: Peace Research Centre, Research School of Pacific Studies, Australian National University, 1990); Greg Fry, "Regional Arms Control in the South Pacific," in David Pitt and Gordon Thompson, eds., Nuclear-Free Zones (New York: Croom Helm, 1987), 46-66.

${ }^{4}$ The wider context of international nuclear concerns over this period is explained in Laurence Wittner, Resisting the Bomb: A History of the World Nuclear Disarmament Movement 1954-1970 (Stanford: Stanford University Press, 1997).

${ }^{5}$ Wayne Reynolds, Australia's Bid for the Atomic Bomb (Melbourne: Melbourne University Press, 2000), 138-218; Richard Broinowksi, Fact or Fission: the Truth About Australia's Nuclear Ambitions (Melbourne: Scribe, 2003), 29-74.

${ }^{6}$ Commonwealth Parliamentary Debates, House of Representatives, 15 May 1962, 2318-2329.

${ }^{7}$ Ibid.
}

${ }^{8}$ ALP Statement of the Federal Executive Re Nuclear Testing and Disarmament, 4 May 1962, Arthur Calwell Papers, Folder 623, Box 201, MS4738, National Library of Australia (NLA); Resolution of Federal Executive on Disarmament and Nuclear Tests, 4 July 1962, Arthur Calwell Papers, Folder 1224, Box 270, MS4738, NLA, cited in Owen Nanlohy, "'A Test Of Loyalty: A History of the Federal Australian Labor Party and the United States Alliance 1960-1967” (BA Honours Thesis, University of Sydney, 2012), 8 \& 26.

${ }^{9}$ Malcolm Saunders and Ralph Summy, The Australian Peace Movement: A Short History (Canberra:

Peace Research Centre, ANU, 1986), 33-35; Wittner, Resisting the Bomb, 203-209.

${ }^{10}$ Ibid.

${ }^{11}$ Ralph Summy, “Australian Peace Movement 1960-67: A Study of Dissent” (Master's Thesis, University of Sydney, 1973), 164.

${ }^{12}$ John Murphy, Harvest of Fear: A History of Australia's Vietnam War (St Leonards NSW: Allen \& Unwin, 1973), 125.

${ }^{13}$ Kevin Clements, Back from the Brink: The Creation of a Nuclear-Free New Zealand (Sydney: Allen \& Unwin New Zealand, 1988), 53.

${ }^{14}$ Ibid.

${ }^{15}$ Saunders \& Summy, Australian Peace Movement, 35-36.

${ }^{16}$ Overviews of Pacific nuclear threats as perceived during this period include: Stewart Firth, Nuclear Playground (Sydney: Allen \& Unwin, 1987); Peter Hayes, Lyuba Zarsky and Walden Bello, American Lake: Nuclear Peril in the Pacific (Ringwood: Penguin Books Australia, 1986).

${ }^{17}$ Overviews of the history of French testing and opposition to the testing may be found in: Bengt Danielsson and Marie-Therese Danielsson, Poisoned Reign: French Nuclear Colonialism in the Pacific (Ringwood: Penguin Books Australia, Second Revised Edition, 1986), and Nic Maclellan and Jean Chesneaux, After Moruroa: France in the South Pacific (Melbourne: Ocean Press, 1998).

${ }^{18}$ Vitaly Fedchenko, "Nuclear Explosions, 1945-2013”, SIPRI Yearbook 2014 (Oxford: Oxford University Press, 2014), 350-351.

${ }^{19}$ Desmond Ball, A Suitable Piece of Real Estate: American Installations in Australia (Sydney: Hale \& Iremonger, 1980) provides a detailed analysis of US installations in Australia and their role in potential nuclear conflicts. 
${ }^{20}$ David Lange, Nuclear Free - The New Zealand Way (Auckland: Penguin Books New Zealand, 1990), 16-17; Clements, Back from the Brink, 67-84.

${ }^{21}$ Ibid., 78.

${ }^{22}$ Fedchenko, "Nuclear Explosions", 350-351.

${ }^{23}$ Vijay Naidu, "The Fiji Anti-Nuclear Movement: Problems and Prospects" in The Pacific: Peace, Security and the Nuclear Issue, ed. Ranginui Walker and William Sutherland (London: United Nations University/Zed Books, 1988), 185-195.

${ }^{24}$ Ibid. 186.

${ }^{25}$ Australian Department of Foreign Affairs, Australian Foreign Affairs Record, 46, no.7 (July 1975), 406.

${ }^{26}$ Danielsson \& Danielsson, Poisoned Reign, 198.

${ }^{27}$ New Zealand Labour Party, Annual Conference Report 1963, 25; Election Manifesto 1963, 10; Annual Conference Report 1966, 35; Election Manifesto 1966, 30; Election Manifesto 1969, 30; Annual Conference Report 1972, 52; Election Manifesto 1972, 30.

${ }^{28}$ Roderick Alley, Nuclear-Weapon-Free Zones: The South Pacific Proposal (Muscatine, Iowa: The Stanley Foundation, Occasional Paper 14, 1977).

${ }^{29}$ Ibid.

${ }^{30}$ Australian Department of Foreign Affairs Record, 46: 7 (July 1975), 406.

${ }^{31}$ United Nations, UN Disarmament Yearbook 1975 (New York: United Nations, 1976), 43-44, 55-56.

${ }^{32}$ Lange, Nuclear Free, 39.

${ }^{33}$ Naidu, Fiji Anti-Nuclear Movement, 186-189; Roy H. Smith, The Nuclear Free and Independent Pacific Movement: After Moruroa (London: Tauris, 1997), 24-27; Ronni Alexander, Putting the Earth First: Alternatives to Nuclear Security in Pacific Island States (Honolulu: Matsunaga Institute for Peace, University of Hawaii, 1994), 138-163.

${ }^{34}$ Honolulu Star Bulletin, 13 February 1982.

${ }^{35}$ Naidu, Fiji Anti-Nuclear Movement, 190-192.

${ }^{36}$ Clements, Back from the Brink, 109.

${ }^{37}$ Ibid., 112-113.

${ }^{38}$ Ibid., 114-116.

${ }^{39}$ Ibid., 117.

${ }^{40}$ Lange, Nuclear Free, 74.

${ }^{41}$ Clements, Back from the Brink, 123-124.

${ }^{42}$ Lange, Nuclear Free, 29.

${ }^{43}$ Ibid., 168.

${ }^{44}$ Joseph Camilleri, ANZUS: Australia's Predicament in the Nuclear Age (South Melbourne: Macmillan, 1987), 104.

${ }^{45}$ People for Nuclear Disarmament, Disarmament Declaration Campaign (Melbourne: pamphlet, 1984).

${ }^{46}$ Makurita Baaro, Director, Political and International Affairs Division, South Pacific Forum Secretariat, "The South Pacific Nuclear-Free Zone Treaty (The Treaty of Rarotonga) in: Pericles Alves and Daiana Cipollone, eds., Nuclear-Weapon-Free Zones in the $21^{\text {st }}$ Century (New York and Geneva: UNIDIR, 1997).

${ }^{47}$ Bill Hayden, Hayden: An Autobiography (Sydney: Angus and Robertson, 1996), 392.

${ }^{48}$ Ibid., 392-393.

${ }^{49}$ Ibid.

${ }^{50}$ Bob Hawke, The Hawke Memoirs (Port Melbourne: Heinemann, 1994), 217.

${ }^{51}$ Ibid., 229-221.

${ }^{52}$ Australian Government Cabinet, South Pacific Nuclear Free Zone - Major Issues (Canberra: Minister for Foreign Affairs Bill Hayden's report to Cabinet on progress achieved by the South Pacific Forum's Working Group on a South Pacific Nuclear Free Zone (SPNFZ), 24 April 1985, Submission No.2806, declassified 2013).

${ }^{53}$ Ibid.

${ }^{54}$ Ibid.

${ }^{55}$ Australian Labor Party, ALP Federal Conference Report 1979 (Canberra: ALP, 1979), 57.

${ }^{56}$ Australian Labor Party, ALP Platform 1982 (Canberra: ALP Secretariat, 1982), 57. 
Jeannette Debney-Joyce, "Venereal Disease in World War I", Proceedings of the 14th Biennial Labour History Conference, eds, Phillip Deery and Julie Kimber (Melbourne: Australian Society for the Study of Labour History, 2015), 63-69. ISBN: 978-0-9803883-3-6.

\title{
Venereal Disease in World War I
}

\author{
Jeannette Debney-Joyce
}

My thesis is on the life and work of Dr Fanny Reading, an orthodox Jewish Russian refugee, who studied medicine at the University of Melbourne and practised in Sydney after her graduation in 1922. Her general practice there was mainly with women and children, some of whom no doubt would have been infected with sexual diseases caught by their partners or husbands. ${ }^{1}$ This paper on venereal disease in World War I will consider the approach championed by another strong and resourceful woman, New Zealander Ettie Rout (1877-1936), and the military and establishment responses to her strategy. Rout advocated a rational approach to the treatment of infected men and women in a "no-blame" way. In order to convince the ANZACs that they should use her kits, she implored them to consider the effects of sexual diseases on the future health of their innocent wives and children and thus deemed sexual education to be crucial. In the contemporary discourse about venereal disease, the myth of the "fallen woman" (the prostitute) can be contrasted to the myth of the idealised woman (the wife and the mother) and these images were certainly exploited by the propaganda machines of both sides of the conflict. In male-dominated societies women were, and still are, identified as the spreaders of venereal disease-especially prostitutes. Nineteenth-century Victorian social attitudes towards sex were prudish and therefore contracting a venereal disease was considered shameful. There was little open discussion about the causes; society blamed nasty foreigners as well as prostitutes, xenophobically calling syphilis the "French pox", and some even believed it to be divine retribution for dissolute behaviour. ${ }^{2}$

Ernest Scott in Australia During the War (first published in 1938) has a short reference to Ettie Rout, "whose friendship and guidance were lavished on thousands of Australians in Paris". ${ }^{3}$ This does not do justice to her work or her insights into the problem of venereal disease. Marilyn Lake has challenged the current attitudes to World War I and the glorification of war in What's Wrong with Anzac: The Militarisation of Australian History. ${ }^{4}$ She has asked how a whole nation could be defined by the actions of white male supremacists and the battle at Gallipoli, which concerned only men within a narrow age range, and how they could be said to speak for contemporary Australia. ${ }^{5}$ Milton Lewis's Thorns on the Rose: The History of Sexually Transmitted Diseases in Australia in International Perspective describes how in wartime the great movement of population, the suspension of the certainties of everyday life with the accompanying psychological changes in the face of death and danger, and the abandonment of peacetime sexual morality contributed to the high levels of infection. ${ }^{6}$ There were pressing non-medical factors that meant the degree of infection control that was theoretically possible at the time simply did not happen. ${ }^{7}$ He has identified these factors as moral concerns, organisational and educational issues.

Jane Tolerton has written an extended biography of Ettie Rout, an early campaigner for a more enlightened approach to venereal disease, as well as the entry in the Dictionary of New Zealand Biography. ${ }^{8}$ Rout was born in Launceston, Tasmania, but she grew up in New Zealand and she was well ahead of her time. P.S. O'Connor's paper, "Venus and the Lonely Kiwi: The War Effort of Miss Ettie A. Rout" provides the background to Rout's work with the ANZACS in Egypt, England and France. Finally, there is Rout's own book, Two Years in Paris (1923), which sets out the rational approach to venereal disease that she promoted. 
Mercedes De Masi's paper, "Sex, Stigma and Scapegoating: Contagious Disease Acts of Victorian England" is also pertinent for this paper. ${ }^{9}$ Masi's analysis of the British Contagious Diseases Acts concludes that they were "the outcome of the belief that strict, scientific laws of social improvement were discoverable and applicable".${ }^{10}$ She notes that, after the Contagious Disease Acts, there were two discernable approaches to dealing with infection in the UK. The first was to isolate and detain the polluting bodies (women of the lower classes); the second was to use pedagogic tactics on those who were educable (the upper middle classes). The exception to this second paradigm shift was the introduction of Regulation 40D during World War I, which made it a criminal offence for any woman with a venereal disease to solicit or have sex with a member of the armed services and provided for compulsory examination of such women. ${ }^{11}$ Masi argues that the Contagious Diseases Acts violated the human rights of women by their controls, forced examinations, registration and resulting degradation, and were in fact a form of "moral panic". She claims that the Acts focused on specific populations in terms of class and gender. ${ }^{12}$

In Britain the Contagious Diseases Act of 1864 had regulated prostitution, especially near army bases. Prostitutes could be arrested, examined for venereal disease and forcibly detained for treatment for up to a year. There were no legal sanctions against their male clients, although there was an outcry from the women's movement at the unfairness of this. ${ }^{13}$ Venereal disease had always been a concern for the armed forces, and, during World War I there were 400,000 hospital admissions for venereal disease among British military personnel, without accounting for reinfections and re-admissions. Roughly 5 per cent of all the men who enlisted in British armies through the war became infected. ${ }^{14}$ Lewis claims that the average incidence rate for the AIF as a whole was around 12 per cent. In Australia, a punitive approach was taken and two camps opened at Langwarrin in Victoria and Liverpool in NSW for infected men. Between August 1914 and September 1918, there were 13,038 military cases in Australia and 40,950 cases overseas. If the figures from Egypt after March 1916 are included, another 1000 cases could be added. It was believed gonorrhea took 72 days to cure and syphilis 74 days. Men who were not deemed cured after four months were discharged..$^{15}$ A Military Order of February 1915 meant that infected soldiers in the AIF were deemed absent from duty and forfeited their pay, including the portion allocated for their family, and their leave was stopped. ${ }^{16}$

The Venereal Diseases Act (Victoria) of December 1916 enforced compulsory treatment for men who had contracted a sexual disease; however, few were willing to make the obligatory statutory declaration about the source of their infection. In the two months following the act, 1650 cases were reported to the Victorian Health Department but only two men were willing to complete the statutory declaration that enabled action under the Police Offences Act against a prostitute. She could then be arrested as a vagrant and her health compulsorily examined. Mr. Elmslie, speaking in the Victorian Legislative Assembly, warned of the "appalling" danger, "There are 4000 women walking the streets of Melbourne spreading the disease", he declared. ${ }^{17}$ The spreading of disease was wholly attributed to the women involved - the men involved were innocent of spreading infection.

In 1918, Miss Vida Goldstein was the principal spokeswoman for the Women's Political Association when a deputation visited the Chief Secretary of Victoria, Mr John Bowser, later Sir John (1856-1936). ${ }^{18}$ Bowser was a gentleman "noted for an absurd shyness with women". ${ }^{19}$ Goldstein informed him that her organisation was against compulsion of any kind in dealing with "vice" of any kind because it meant sex and class legislation of "the most pernicious kind" 20 and was only the Contagious Diseases Act "in a new Dress". ${ }^{21}$

During World War I, Ettie Rout worked closely with the ANZAC troops and authorities in Egypt and in Britain to take a more practical and rational approach to venereal diseases such as gonorrhea and syphilis. She was generally regarded as a thorn in the side of the authorities, being described as "highly objectionable in every way" and a "considerable bother". ${ }^{22}$ Historian Milton 
Lewis describes her as "redoubtable ... a self appointed expert on wartime control of venereal disease and later an internationally recognized exponent of sex education". ${ }^{23}$ Rout's war work was transnational, taking her from New Zealand to Egypt, Europe and England, and her influence was felt in all these countries. Though she was not always regarded positively at the time, there were those who supported her approach. Rout was not a nurse; she had trained as a typist and, with her skills in shorthand, had worked as a court clerk in New Zealand. She was a radical and a socialist and also a vegetarian; she did not wear corsets because she preferred loose-fitting clothing; she often wore plain long skirts, men's jackets and even boots; she like to ride a bicycle; she cut her hair short and she upset the Establishment. In 1910, she started the labour paper, the Maoriland Worker, with the New Zealand Shearers' union. She was not a member of the union but she edited the first six editions of the Maoriland Worker without payment, until the editorship was taken over by the New Zealand Federation of Labour in 1911.

In 1915, Rout formed the New Zealand Voluntary Sisterhood and invited women between the ages of 30 and 50 years to accompany her to Egypt to support the New Zealand troops there. ${ }^{24}$ In 1916, she went to Egypt against the wishes of the New Zealand government with a small group of 25 like-minded women. Egypt at that time was a British protectorate and Sir John Maxwell was the Imperial Commander-in-Chief. Rout saw that venereal disease was rife there. By the end of 1915, there were 10,000 cases and, by the middle of 1916, the infection rate amongst Australians was 178.8 per thousand, six times the incidence amongst British troops housed in Egypt. ${ }^{25}$ Rout's work in Egypt was mainly concerned with providing troops with better, fresh food, first at the YMCA canteen in Esbekia. She also obtained sporting equipment from New Zealand for the New Zealand troops. She moved to London in June 1917 where she made a practical study of the situation, tramping the streets, talking to prostitutes and visiting the brothels. ${ }^{26}$ By 1918, Rout was in Paris where she lived for two years. She was mentioned in dispatches and very briefly in Australia's official history of the war. ${ }^{27}$ She never received the recognition she deserved in her lifetime for the work she did. Her writing and letters were censored in New Zealand and anyone publishing her ideas there incurred a fine of $£ 100$.

The military authorities preached "moral prophylaxis" but Rout believed that "physical prophylaxis" and sex education would be far more effective in protecting the health of the troops than lectures on chastity. She wrote to W.H. George of the New Zealand National Council of the YMCA that "the ordinary Australasian soldier-particularly the Australian-does not deliberately intend to be vicious. He is simply and frankly a pagan". ${ }^{28}$ She implied by this that any appeal to such men on moral grounds would simply fall on deaf ears. Rout claimed that there was "no necessary connection between Vice and Disease". ${ }^{29}$ She wrote that venereal diseases were "dirt diseases", ${ }^{30}$ not diseases of morality. Rout emphasised the fact that venereal disease was a medical problem and that it should be approached as a medical problem. This idea was certainly not accepted by the military authorities in Britain or New Zealand in 1916. Rout was roundly accused of promoting vice and was disliked intensely, particularly by the women of New Zealand, who saw her as an advocate for vice and sin, the equivalent of a "fallen woman" in their eyes.

Rout's solution to the problem of venereal disease for both men and women was cleanliness. She believed that the servicemen cared deeply about the health of their women and children at home, even if they did not care about their own health. By emphasising their responsibility to their wives and future children, she persuaded the soldiers to use the kits she provided. These kits contained Condy's crystals (potassium permanganate) a disinfectant for washing, condoms (much thicker than the modern ones) and calomel ointment (mercurous chloride) ${ }^{31}$ Rout also believed that sex education was vital because it would make servicemen more aware of the dangers of unprotected sex. Rout worked solidly against the negative attitudes towards her ideas during and after World War I. She disliked the Wowsers or the puritans who argued that using physical prophylaxis spread "immorality". ${ }^{2}$ She had taken her typewriter and 
cyclostyling machine with her to war. An excellent typist, she was thus well equipped to type and then print her circulars and letters. The circulars contained clear instructions for the men on how to use the kits. ${ }^{33}$ She also wrote circulars for the prostitutes in both English and French on how to take preventative measures both before and after "connection". She worked actively with Military Command, where she could, to raise awareness of her "physical prophylaxis" approach. She was also able to convince wealthy friends and supporters, like H.G. Wells, to give her money so that she could set up the kits.

Writing in June 1919 in a memo to the ANZACs, she said that the English, Australian and New Zealand YMCAs had tried to close blue-light rooms in the Beaver Hut (Canadian YMCA) and the Eagle Hut (American YMCA) on the Strand. These blue-light rooms appear to have been designated areas where a soldier could seek medical help or a prophylaxis kit. She was annoyed that the YMCA authorities would not allow their lecture halls to be used for medical lectures, even when these had been approved of by the relevant military authorities. ${ }^{34}$

After the cessation of war in November 1918, Rout described the chaos in Paris when soldiers poured into the city; they were "exhausted, distracted, nervous, restless and reckless", she later wrote. ${ }^{35}$ Even before November 1918 the army authorities were meant to meet the men at the stations but, after the Armistice, she observed, the system broke down completely. She regularly got up at 5am when New Zealand troops were due in at the Gare du Nord to greet them after their long, tiring, overnight trip. She gave them each a kiss on the cheek and handed out disinfection kits and cards with the address of Madam Yvonne's clean brothel. She tried to persuade the men to go to a hotel and have a sleep first. It seems that she had booked out an entire hotel in her own name and that she would write the room number on the soldier's hand in indelible pencil. At the hotel there was a supply cupboard of disinfection material that the soldiers could access at any time. She persuaded the men to leave their gear with her for safe-keeping, including their money. She limited each man to 50 francs a day, unless it was a special occasion. ${ }^{36}$ The prostitutes might charge two to three francs a session; a British private in the infantry only received about 10 francs a week whereas his Canadian and Australian counterparts were paid "five times as much" ${ }^{37}$ Each day, when the soldier returned for another 50 francs, Rout made sure that he had a new prophylaxis kit. She wrote that the ANZACs were "perfectly good-tempered and nice-minded" 38 over the restrictions she placed on them because they realised that she was acting in their interests. She tried to create a "home from home" for them. "I sat on thousands of pounds of the men's money, and uncounted pay books, watches and other personal property", she wrote. ${ }^{39}$

Rout also managed to achieve workable and friendly relationships with the British Military Police (BMP) in Paris. Over time, the BMP set up an informal routine with Rout and brought back to her any ANZACs they found drunk, dazed, or "broke". They even sent a few back to her in a taxi with cards pinned to their clothing. In return, there was an understanding that all the ANZACs who had benefitted from this lenient attention from the BMP would contribute to "Jack's Box", which was the Military Police Mess Fund. Rout claimed that at any one time there were between 40,000 and 50,000 officers and men of the British Army who were out of action as a result of venereal disease.

Rout's approach was non-judgmental, she appealed to the better nature of the ANZACs, she wrote that "the unforgiveable sin ... would be for a man to go home and sow in the body of an innocent wife the seeds of disease he had picked up in foreign lands in moments of excitement and folly". ${ }^{40}$ Untreated syphilis can cause various problems with pregnancy, miscarriage, stillbirth, premature delivery or death of the baby shortly after delivery. Babies that survive often have a low birth weight and may have become infected with syphilis in the womb. This is called congenital or constitutional syphilis and can result in serious kidney and bone damage, progressive blindness, deafness, atypical facial features and mental retardation. ${ }^{41}$ Rout wrote that there was one appeal that never failed to touch the soldier-"the Appeal on behalf of his own women and children". ${ }^{42}$ 
It took a long time for the concept of "physical prophylaxis" to be accepted. In 1922, Mr D. Poole, writing to the British Medical Journal, thought that sexual disease was the result of evil and a descent to vice, and that fear would the best deterrent. ${ }^{43}$ The result of this fall, he wrote to the editor, would be "universal physical weakness and degeneracy unparalleled in history". A more enlightened correspondent, Mr J. Armstrong, thought that the situation had developed because of the virility of men and the slackness of the authorities. He felt that if venereal diseases were notifiable and treated like other conditions, then the diseases could be brought under control. ${ }^{44}$ Rout also wrote to the British Medical Journal supporting those soldiers who had been accused of deliberately infecting themselves with venereal disease to escape active duty. She said that for "those of us who really know war", these poor soldiers excited only pity. ${ }^{45}$ A total of 43,933 soldiers of the AIF were admitted to hospitals overseas for venereal disease between 1915 and 1918. This was an average figure 70.0 per 1000 men. ${ }^{46}$ There were 416,891 hospital admissions among British and Dominion troops during World War I. ${ }^{47}$

Why was there such resistance to Ettie Rout's message and approach to venereal disease during the war period? The medical and military authorities recognised the breadth of the problem and the effect upon the war effort. New Zealand's General Godfrey in Cairo in 1915, for example, thought that he could lose 10 per cent of his troops if the recommended "washout" method failed. He had ordered 5000 tins of Metchinkoff s Ointment for his troops but this caused blistering, and the prostitutes, who each might service between twenty and thirty men a day, did not like it. However, the local people in Cairo apparently found that it was effective against hair and body lice. ${ }^{48}$ Although the military commanders could see the efficiency and effectiveness of the physical prophylaxis kits, they could not be seen to condone "Vice". Public opinion was against them on this issue.

There was an important myth that had to be sustained, which was the myth of the "fallen woman". The propaganda of the time identified the prostitute as the "fallen woman" and the "source" of disease; for instance, posters warned enlisted men about the enemy said to be hidden in the bodies of prostitutes. ${ }^{49}$ The prostitute was depicted as a "slut", she was "Susie Rottencrotch", she was the "enemy": a sweet-innocent faced young girl who could be a "booby trap". The myth of the prostitute as the "fallen woman" and "source" can be contrasted with the image of the idealised wife or girlfriend back home. Rout effectively exploited this conventional dichotomy when she appealed to the men to use the kits, and it worked for her it seems.

Rout's rational approach towards sexual infection was to be resurrected later in the twentieth century when the AIDS epidemic occurred. Regarded with dislike in New Zealand and elsewhere, Rout and her work polarised opinion. She wrote to her friend H. G. Wells in 1922 that, "It's a mixed blessing to be born too soon". ${ }^{50}$

Jenny Debney-Joyce is a PhD history student at Federation University Ballarat, researching the life of Dr Fanny Reading, a Jewish doctor who studied medicine at the University of Melbourne during World War I.

\section{Endnotes}

\footnotetext{
1 Suzanne Rutland, The Jews in Australia (Melbourne: Cambridge University Press, 2005), 46.

2 Simon Willis, How Our Ancestors Died (Barnsley, South Yorkshire: Pen and Sword Books Ltd., 2013 ), 184.

3 Ernest Scott, Australia During the War, Vol. 11 of The Official War History of Australia: The War of 191418.

(Brisbane: UQP in association with The Australian War Memorial, 1989), 727.
} 
4 Marilyn Lake and Henry Reynolds, What's Wrong with ANZAC? The Militarisation of Australian History (Sydney: New South Press, 2010).

5 Ibid., 16.

6 Milton Lewis, Thorns on the Rose: The History of Sexually Transmitted Diseases in Australia in International Perspective (Canberra: Australian Government Publishing Centre, 1998), 153.

7 Ibid.

8 Jane Tolerton, Ettie: A Life of Ettie Rout (Auckland: Penguin, 1992); Jane Tolerton, "Rout, Ettie Annie", Dictionary of New Zealand Biography and Te Ara - Encyclopedia of New Zealand, updated 28 January 2014. http://www.TeAra.govt.nz/en/biographies/3r31/rout-ettie-annie.

9 Mercedes DeMasi, "Sex, Stigma, and Scapegoating: The Contagious Diseases Act of Victorian England", Social Sciences Journal, 7 no.1 (2007): 17. http://respository.wcsu.edu/ssj/vol7/iss1/17.

10 Ibid., 96.

11 Ibid., 97.

12 Ibid., p.98.

13 Richard Marshall, “The British Army's Fight Against Venereal Disease”, in Heroic Age of Prostitution, (http://ww1centenary.oucs.ox.ac.uk/?p=2255).

14 Ibid.

15 Lewis, Thorns on the Rose, 157.

16 Ibid., 158.

17 “The Scourge of Venereal Disease”, Every Week (Melbourne), 27 September 1917, 3.

http://nla.gov.au/nla.news-article 153439590.

18 "The Social Evil", Truth, 13 July 1918, 6. http://trove.nla.gov.au/ndp/del/article/130172330.

19 Margaret Vines, "Bowser, Sir John (1856-1936)", Australian Dictionary of Biography, National Centre of Biography, Australian National University, http://adb.anu.edu.au/biography/bowser-sir-john5316/text8977.

20 Truth, 13 July $1918,6$.

$21 \mathrm{Ibid}$.

22 P.S. O'Connor, "Venus and the Lonely Kiwi: The War Effort of Miss Ettie A. Rout", NZ Journal of

History, Part 1 (1967): 21.

23 Lewis, Thorns on the Rose, 158.

24 Tolerton, "Rout, Ettie Annie".

25 O'Connor, "Venus and the Lonely Kiwi", 16.

26 Ettie A. Rout, Two Years in Paris (London: E. Rout, 1923), 9.

27 Jane Tolerton, “A Lifetime of Campaigning: Ettie Rout, Emancipationist beyond the Pale", International Journey of the History of Sport, 18, no.1 (2001): 73-9.

28 O'Connor, "Venus and the Lonely Kiwi", 20.

29 Rout, Two Years in Paris, 9. Author's capitalisation.

$30 \mathrm{Ibid}$. Author's emphasis.

31 Tolerton, "A Lifetime of Campaigning”, 8.

$32 \mathrm{Ibid}$. Author's capitalisation.

33 Ibid.

34 Rout, Two Years in Paris, 20.

35 Ibid., 6.

36 Ibid.

37 Marshall, "The British Army's Fight Against Venereal Disease".

$38 \mathrm{Ibid}$.

39 Ibid., 17.

40 Rout, Two Years in Paris, 16.

41 Willis, How Our Ancestors Died, 186.

42 Rout, Two Years in Paris, 9. Author's emphasis.

43 Rout, Two Years in Paris, 9.

44 Ibid. 
45 Ibid. Author's emphasis.

46 Lewis, Thorns on the Rose, 160.

47 Marshall, "The British Army's Fight Against Venereal Disease".

48 O'Connor, "Venus and the Lonely Kiwi", 1-2.

49 Elizabeth Gettelman and Mark Murrmann, "The Enemy in Your Pants: The military's decades-long war against STDs", MotherJones, http://www.motherjones.com/politics/2010/05/us-army-std/enemy-yourpants-9.

50 Tolerton, "Rout, Ettie Annie". 


\title{
Worker for Peace from behind the Iron Curtain
}

\author{
Doris LeRoy
}

This paper examines the life of Professor Josef Hromádka, his close involvement with the Soviets, his visits to Australia and his influence on those Australians who shared like views. Hromádka was a Czech Lutheran pastor, who became an influential theologian worldwide despite embracing socialism. He was a founding member of the World Council of Churches. Hromádka was an undoubted worker for peace, but also was a supporter of the Soviet Union and world communism and awarded the Order of Lenin, whilst remaining the ideological leader of the evangelical movement in Czechoslovakia. The Australian receptions given Hromádka in 1954 and 1956 were extremely mixed. They verged on hysterical anti-communist vitriol to an acceptance that he was a genuine worker for peace, attempting to find a middle way for those Christians forced to live under Soviet rule. Those Czechoslovakian refugees living in Australia regarded Hromádka as a traitor.

Professor Josef Hromádka was an ordained Czech Lutheran pastor, who had served also a chaplain during the First World War. Extensive theological studies saw him become a leading theologian in his own country, holding teaching positions at the Protestant Theological Faculty of the Charles University in Prague-from 1920 to 1966. During World War II he escaped to the United States where he held the position of visiting Professor, Theology, at Princeton Theological Seminary until 1946. He also was supportive of socialist ideology. On his return to Czechoslovakia after the war he became a member of an Action Committee for the Evangelical Church of Czech Brethren set up in 1948 which welcomed the new communist government, anticipating that it would "preserve the deepest traditions of freedom and justice" in Czechoslovakia. ${ }^{1}$ The Protestant Evangelical church to which he belonged had ties to the Presbyterian church. Hromádka "advocated dialogue with the Marxists, arguing that the Marxist revolution was a revolt against unjust social orders, not against God". Hromádka regarded the birth of socialism in Czechoslovakia with "sober Christian realism". The church, he said, stood "amid great historical changes" which could not be sidestepped. It could, of course, ignore the new situation and look to its past, "but such an attitude to the problems of today would weaken us spiritually, would withdraw the church to the fringe of events".

Hromádka was a founding member of the World Council of Churches (WCC) in 1948, and had a debate with John Foster Dulles at that time which indicated the deep East/West divisions that were to follow. "Henceforth the West must share world responsibility with the East, and this means that the West must get over its 'almost metaphysical horror' of the new world trends and their eastern leader, Soviet Russia". ${ }^{4}$ Hromádka served on its executive from 1954-1961. This did not save him from the unwelcome attention of those in the West who mistrusted any who espoused Christian-Marxist principles, and who co-operated with the Communist regimes. As well, Hromádka was the founder of the Christian Peace Conference (CPC) working behind the Iron Curtain for peace. Despite there being people in the organisation recognised as wanting peace, the same charges of control from Moscow and infusion of "Moscow Gold" were levelled as with the communist-influenced World Peace Council (WPC), of which Hromádka was also a member. Western opponents of communism claimed the WPC as being the 
organisation through which the Soviets organised their "front" organisations and the CPC was listed as a "front" organisation. ${ }^{5}$ Hromádka was influential beyond the Iron Curtain, often compared with Anglican Dean Hewlett Johnson, another priest who claimed that there was no incongruity in Christians working with communism, and who extolled the benefits of the socialist system. However Hromádka's theological standing far outstripped that of Johnson. Johnson's visit to Australia in April 1950 had created extreme unrest among the Australian populace. ${ }^{6}$

\section{Australia}

Hromádka's influence extended to Australia, in particular on the so-called "Peace Parsons", Reverends Dickie, Hartley and James of the Victorian Branch of Australian Peace Council (APC), which worked closely with the WPC. There were some clerics who were prepared to defy their churches and become involved in organisations such as the APC, even though this organisation was closely aligned with the Communist Party of Australia (CPA), had some union support and was subject to ASIO surveillance. The Peace Parsons claimed the situation in Czechoslovakia between Church and State proved that communism and the church could co-exist, with both working toward the betterment of mankind. Since the political and religious climate in Australia was, in the main, anti-communist during the Cold War, the Australian reception given Hromádka in both 1954 and 1956 was extremely mixed, verging on hysterical anti-communist vitriol to a more measured acceptance that he was a genuine worker for peace, attempting to find a middle way between those Christians who lived under Soviet rule and the State. An additional complication was created by the influx into Australia of immigrants from Eastern Europe, some of whom were avidly anti-communist. The CPA had a negative attitude to those migrants who had chosen not to live under communist rule and who came to Australia instead. The CPA actively campaigned so that these migrants were discriminated against in obtaining employment. ${ }^{7}$ The mainstream Australian religions had adopted an anti-communist stance, despite some being prepared to host Hromádka's visit in the hope it might lead to better understanding. ${ }^{8}$ Most certainly the Australian Government followed the anti-communist line adopted by both the British and US Governments. ${ }^{9}$

Reverends Victor James and Frank Hartley, of the APC, had met with Hromádka when they visited Czechoslovakia. James and Hartley have been assessed as unable to objectively appraise the communist societies they visited, since they had a blinkered view regarding the role played in those societies by the church. Hromádka played a vital role in establishing that view. ${ }^{10}$ Hartley recorded in his diary that Hromádka had been extremely helpful to them, that he and James dined at his home, and that he travelled with them to Moscow. This connection was bound to place Hromádka under greater suspicion in Australia, as Hartley and James were considered by many to be colluding with communists. In 1951 Hartley wrote "To me, Professor Joseph Hromadka represents a bridge between East and West, that is why I crossed the world to see him". ${ }^{11}$ Rev. Alfred Dickie had also formed strong bonds with Hromádka, and followed Hromádka's utopian vision of "the church as a bridge between East and West". ${ }^{12}$

\section{World Council of Churches}

The WCC was an important link for Australians to become informed of events occurring overseas, since isolation was one of the major problems encountered in Australia in the 1950s. To some extent this isolation was counteracted by newspapers and magazine reports, but of course such sources had their varying stances. A prime example of this was the Anglican press in Sydney, where the competitive Anglican Church Record (ACR) and the Anglican very often provided alternate versions of the same events. So it was that Hromádka's first Australian visit after the 1954 WCC Evanston gathering came at a time of unrest. 
Hromádka and other Iron Curtain clergy had met antagonism from within the US for their attendance at the WCC meeting at Evanston. ${ }^{13}$ Also complicating the WCC meeting was the attitude of the US security forces toward those eleven clergy from behind the Iron Curtain that had been granted visas to attend. There was opposition mounted to the WCC by the International Council of Christian Churches (ICCC) a fundamentalist international council headed by American Dr Carl McIntire. This organisation held its meetings at the same time as the WCC meetings, and claimed that the WCC was "communist inclined, because it included people like Hromadka who co-operated with communist regimes". ${ }^{14}$ The emphasis on anti-communism in the US also made for an uncomfortable visit for some clergy, since participants were asked to keep other Iron Curtain clergy under surveillance. Norman J. Hjelm-later to be acting deputy secretary of the Lutheran World Federation-outlined the inability of those from outside the Iron Curtain to appreciate the difficult conditions confronting those forced to find accommodation with the communists. ${ }^{15}$ The pangs so obviously felt by Hjelm regarding incompatibility of East/West surfaced when:

the Australian Council of Churches chose not to issue an invitation to Dr Hromadka to speak when he visits Australia next month. The general Secretary of the Council, Dr Malcolm Mackay reported that the special committee of Australians appointed to discuss Dr Hromadka's visit had decided it could do no more than welcome Dr Hromadka since it cannot align itself with the various 'peace' councils sponsoring his visit. ${ }^{16}$

Hromádka had moved a motion at Evanston supporting "the communist intervention in Korea", passed despite opposition from "the Americans and some members of the Australian delegation, including Malcolm Mackay". Mackay was formerly a member of the University of Sydney Student Christian Movement. The Australian Student Christian Movement (ASCM) did not endorse Hromádka's Australian meetings even though Hromádka was involved in the World Student Christian Federation (WSCF). Hromádka, who "believed in being in 'critical solidarity' with the post-war communist governments" was described as a "mentor" for Hartley and Dickie. Boyce Gibson, a stalwart of the University of Melbourne SCM also opposed Hromádka's visit and meetings. ${ }^{17}$ This stance was not adopted by all ASCM identities. Margaret Holmes acted as chauffeur for Professor Lonsdale when Lonsdale and Hromádka were in Sydney. As well, the formation of committees for International Affairs across Australia, as an initiative of the WCC ${ }^{18}$, caused dispute amongst ASCM members. ${ }^{19}$ The fear was that these committees would be under communist control-a suspicion also voiced regarding the WCC, because of the membership of identities such as Hromádka.

Anglican Rev. D.W.B. Robinson published his critique of Hromádka in the ACR, where Hromádka was the subject of a two page critical spread. ${ }^{20}$ Dr Mowll, Archbishop of Sydney and Primate of the Anglican Church in Australia, was unmoved. He advised the Clergy School at Moss Vale the day of his return from Evanston that he:

would act as host for Dr Josef Hromadka the distinguished Czech theologian and member of the World Council of Churches, who reached Australia yesterday at the invitation of the Peace Forum in Melbourne. Dr Mowll made it clear he was welcoming Dr Hromadka 'as a convinced fellow-Christian' and that he was not associated with the groups who invited Dr Hromadka, nor did he necessarily endorse their views. ${ }^{21}$

The Anglican editorial welcomed Hromádka to Australia, claiming the Peace Quest Forum (sponsors of the Peace and Goodwill Assemblies) was what it purported to be: "a band of true Christians, mostly ministers of religion, and including Anglican clergy and Quakers, genuinely 
and constructively interested in peace" and urged Anglicans not to be deterred from attending the meetings and to make their own independent decision. ${ }^{22}$ Other influential Anglican clergy showed support for Hromádka; Bishop J. S. Moyes of Armidale gave an interview to the Anglican:

Dr Hromadka was a valued member of the WCC, a spiritual hero, a symbol of the hopeless division of the Christian world between East and West. He decided he had to cooperate with those who denied his Christian faith to take part in the reconstruction of his country, he was disappointed at the abandonment of Czechoslovakia by Western allies 1938. He fled on the advice of police. He taught in the US at Princeton-returned to Czechoslovakia, all along a convinced socialist. The men who rule Czechoslovakia are honest and hard workers. He could have joined the party years ago but not now, he is too well known. 'The Lord asks that I live among Communists, I love them; Christ died for them also'. ${ }^{23}$

Hromádka's ASIO file reveals that written protests against Hromádka's visit were received by parliamentarians and forwarded onto Prime Minister Menzies, in addition to protest letters being published in the local newspapers. ${ }^{24}$ Rev. John James Eric Owen, of the Peace Quest Forum, was not aligned with the WPC. He was a Presbyterian minister, who had been Moderator of the Presbyterian church in Victoria, and was shocked that the Menzies government did not accept that Hromádka was a genuine worker for peace between the East and the West. Owen's protestations fell on deaf ears, despite having previously had an interview with Menzies regarding the credentials of the Peace Quest Forum. Though the Peace Quest Forum had been explicitly formulated so that there was no communist involvement, it still was subject to scrutiny by ASIO. This prompted Menzies to make a statement in the House of Representatives that there was evidence that there was communist infiltration into the Peace Quest Forum, and especially into the Australian Convention of Peace and War, which was being organised for September $1953 .{ }^{25}$ Owens then met with Menzies, who made another statement in the House that "I entirely accept what Owens has told me". However Menzies still claimed, despite Owens being "a man of great character" and "certainly not a communist", that the government had information "there had been a great deal of Communist activity...quite real, and giving a character to the proceedings that will occur" ${ }^{26}$ This led to the reluctant withdrawal of Dr Harold Woods from the Forum, his position as headmaster of the Methodist Ladies College in Melbourne made his involvement in any such suspect activity undesirable. While Owen decided to stay in the organisation and the convention was held, the Peace and Goodwill Assemblies a year later came under the same suspicion from the Menzies government.

The attendance of the two overseas visitors, Professor Hromádka and Professor Kathleen Lonsdale (a Quaker and noted nuclear physicist who worked for peace) for the Peace and Goodwill Assemblies was noted and they received the full attention from ASIO. In Sydney Hromádka addressed meetings with Professor Lonsdale. However, it was typical of the times that Lonsdale, as a woman, did not receive the accolades due to her status as a physicist and less ASIO scrutiny. Their meetings were well publicised. Margaret Holmes was charged with the duty of chauffeuring Lonsdale. Her recollections reveal that the meetings in Sydney were slightly less confrontational than those in Melbourne - and when appeals were made to contribute to the cost of bringing out the speakers huge amounts were raised from working class people. ${ }^{27}$ The ASIO report on a NSW CPA meeting on 18 August claimed Hromádka's visit "is to be organised by the Peace Council" and that "he will make a lecture tour of N.S.W. prior to going to the Assembly". The report claimed that "attempts may be made by W.C. Wentworth to organise the Fascist New Australians in a demonstration against this visitor. For this reason it is important that there may be many comrades present wherever he should appear" ${ }^{28}$ W.C. Wentworth was the strident anti- 
communist Liberal Member of the House of Representatives, who frequently associated with Eastern European anti-communists. It must be remembered that the WPC was a suspect organisation, which many unionists joined, and the muscle provided by those unionists certainly was used to ensure meetings could be held. ${ }^{29}$

Unfortunately for Hromádka, the influence Dr Mowll had in Sydney was not reflected in the Melbourne diocese. Hromádka had a very difficult time in Melbourne in 1954. While he did receive assistance from some sections of the churches in Australia, when he spoke at the Assembly Hall in Melbourne on 16 September 1954, he was met with an unruly mob. Earlier the same day he spoke to 800 students at University of Melbourne, where "New Australians hissed and booed him and distributed pamphlets against him. They were sent away by the University authorities". Hromádka maintained "that Christians who had been persecuted in Communist countries had been persecuted for political rather than religious reasons". He also claimed "the Christian Church has been identified with the middle classes and is out of touch with the workers". Rev. Don McCrae, who chaired the meeting, refused permission to "a Roman Catholic clergyman the right to reply for just two minutes". ${ }^{30}$

The "Peace and Goodwill rally" at the Collins St Assembly Hall that evening met with even more violent confrontation. The ASIO report listed Stephen Murray-Smith (a member of $\mathrm{CPA}$ ) as "a journalist returned Czechoslovakia" and "one of the main persons associated with the organisation and holding of the meeting". While there can be no doubt of the support received from the CPA for the Peace and Goodwill Assembly meetings, evidenced by the ASIO files on the CPA meetings around the country, it is doubtful that the CPA initiated the meetings. The Peace Parsons (Reverends Dickie, Hartley and James) were listed on the platform with Anglican Canons Maynard and Thomas-all active in the APC. The platform was completed with Professors Hromádka and Lonsdale, Reverend J. F. Long and Reverend J. Eric Owen (Peace Quest Forum). Owen was the chairman. The meeting "was very disorderly, anti-Communists and members of the Czechoslovakian community interjecting profusely". The ASIO lists of others at the meeting included those suspected as being complicit with suspect peace overtures, such as the Australian Convention on Peace and War in 1953. Also listed as antagonists were Vladimir Borin (Free Czechs); Rev. Norman Hill, Vicar of St Marks Anglican Church, Fitzroy; and another "Nicholls", supposedly the son of a Presbyterian minister. ${ }^{31}$ The newspapers widely reported the meeting. "Crowds of New Australians bearing banners with anti-communist slogans milled about the Assembly Hall ... Nearly five hundred people jammed the footpath ... The police had to separate several groups when blows were exchanged". ${ }^{32}$ Inside, Anglican priest Rev. Norman Hill grabbed the microphone to criticise Hromádka, physically fending off Rev. Eric Owen. ${ }^{33}$

Hill was identified by Peace Quest officials as the "ringleader" of the problems at the Assembly Hall. Objectors had entered the hall in the dark and were already seated before the meeting started. Rev. Owen appealed to Hill to "behave". Hill claimed it was he who brokered the agreement that "Mr Vladimar Borin, leader of the Free Czechs" could answer Hromádka. It was only after this a concession was made that the meeting could continue. ${ }^{34}$ Rev. Hill thus totally ignored the tolerant lead of his primate, Mowll, toward Hromádka. Hill was avidly anticommunist and a supporter of Eric Butler-an Anglican layman who became the backbone of the Australian League of Rights. Professor Lonsdale was permitted to address the meeting in relative calm, stating "she was not a communist, but a Peace-lover. She spoke of the effects of war and the atom bomb, and of the damage to property and the loss of life in war". However, "then Hromádka endeavoured to speak, but could not be heard through the uproar. To stop the noise the National Anthem was played three times." Rev Hartley then made the usual collection toward the cost of hosting the overseas visitors, and $£ 124.5$.0 was collected. ${ }^{35}$

The Anglican decried the behaviour; it was "unthinkable that an eminent Christian visitor be howled down. Were the mob new or old Australians?" and considered the conduct was 
"harking back to the Petrov departure". ${ }^{36}$ Since the "Red" Dean had not met similar treatment in 1950, the likely cause was Hromádka's visit, and his connection with the communists. Any organisation that claimed to be working for peace was suspect; so was any person advocating cooperation with communists. Meetings were addressed across Australia. ASIO informants detailed that the CPA vigorously encouraged their members to attend these meetings, which enabled ASIO to make detailed lists of those under ASIO surveillance who attended. The Rev. Gordon Locksley file was maintained until 1962 when his visit to Papua New Guinea for the Assembly of Papua Ekalesia received attention. ${ }^{37}$ Locksley had played host to Hromádka at Cromwell College, St Lucia, in 1954. In 1962 Australia was sensitive to the possibility of communist infiltration from the north. The contact made in 1954 was sufficient to raise suspicion. ASIO considered "International communism is taking an increasing interest in Oceania". Hromádka was described in the ASIO report on his contact with Locksley as "one of the cleverest men ever to visit the West from Iron Curtain countries". ${ }^{38}$ However the Regional Director in Papua was able to reassure headquarters that the assembly seemed innocuous, being the handover to Papuans of the London Missionary Societies activities. A full list of clerics attending was proffered, but services were conducted mainly by Papuan clergy with the visitors being mere observers.

Hromádka departed Australia on 7 October 1954 after a torrid visit with lasting repercussions for those associating with him. His departure was observed by ASIO, the report listing all those farewelling him. ${ }^{39}$ Hromádka reported on his return to Europe that "In America it was in particular the press that made it unpleasant for me and my assistants. In Australia they tried to break up public meetings at which I appeared. They did it with pamphlets and newspaper attacks and with the most crude means in the meetings themselves". ${ }^{40}$ It is uncertain what part did W.C. Wentworth played in the animosity displayed to Hromádka What is certain is that he did not intend to leave matters lie, even after Hromádka had returned to Czechoslovakia. Wentworth was prone to seek information from ASIO. On 7 October 1954, he wrote to Senator Spicer, Attorney General, claiming he "had heard a rumour" that Hromádka had been "one of the people who carried out the purge at Carolus University in Prague in 1948". He requested that "your Department" check up on this and "let me know if it is correct". This request was forwarded to Charles Spry, Director-General of ASIO, who replied on 7 November, "We have no comments to make on this matter". Wentworth was advised by Spicer to ask the Department of External Affairs. This Wentworth did, ultimately receiving an acknowledgement from R. G. Casey, Minister for External Affairs, on 8 December that he would have enquiries made. Again a reply came from Spry, on 16 December, "we have no information on Hromdaka regarding this matter". ${ }^{41}$

\section{WCC Executive Consultation in Sydney, 1956}

Both the archbishop of Canterbury and Mowll, the primate of Australia, were supportive of the aims of the WCC. The Sydney Consultation was attended by the Central Executive of the WCC, which included Hromádka, as well as 100 Australian church leaders. At the end of the four days consultation a Festival of Faith evening was held at the Sydney Showgrounds. The Festival was attended by 25,000 people, with the official party including such luminaries as Prime Minister Menzies, Dr Evatt, Leader of the Opposition, Queen Salote of Tonga, the Lord Mayor of Sydney, the Governor of New South Wales, the Premier of New South Wales and 15 members of the WCC Central Executive. ${ }^{42}$ The format of the meetings was WCC consultations during the day with public meetings in the evening. Douglas Dargaville, an Anglican, attended this consultation and has left invaluable recollections of the event. As has ASIO, who had extensive files on some attendees-including Hromádka. Dr Hromádka and Bishop Otto Diebelius, the head of the German Evangelical (Lutheran) church who had openly opposed the Nazi party during WWII, both spoke regarding differences between the nations, and argued that national differences should 
be disregarded so that individual Christians were be able to work towards the establishment of the union of churches across national borders. ${ }^{43}$ Diebelius was not a supporter of communism, and had great difficulty in administering to a church with connections in the East. Dargaville observed that the press concentrated on these two churchmen, who were attempting to cope with church life within communist jurisdiction. Hromádka shunned publicity. Dargaville felt "this was understandable since the press treated him as a plaything, prying into every detail of his life to see how far he is a communist". Rev. Eric Owen, who had had previous contact with Hromádka on his visit in 1954, tried to protect him "from this embarrassment" ${ }^{44}$ Such protection was difficult, since the ICCC also held their rival meeting in Sydney in opposition to the WCC. Protest rallies had been organised around the country by the Bible Union of Australia. Their express target was Hromádka "because he was serving the communist cause" ${ }^{45}$ McIntire addressed a rally to welcome the church leaders to Sydney: Dr Kinney from America; Burgomaster Waarnaar from Amsterdam; Rev. Mazierski of the Polish Reformed Church in exile in London; Rev. Ormeo, president of the Far Eastern Council of Christian Churches in the Philippines; Rev. Tow of Singapore; and Rev. Kennedy of California. McIntire specifically attacked Hromádka, claiming that "Thousands of Christians behind the Iron Curtain believe Dr Hromadka has betrayed the Church of Christ...The International Council of Churches repudiated both Dr Hromadka's doctrines and concept of the Church". ${ }^{46}$

Hromádka's ASIO files reveal that surveillance was maintained, both on him (including reports from overseas, and until his death) and those with whom he had made contact during his visits. Recorded also was Hromádka's comment during his 1956 visit regarding the Royal Commission on Espionage, prompted by the defection of Vladimir Petrov: "Hromadka decried the breaking down of relations between the USSR and Australia on the evidence of a man who, he said, must rate as a traitor to his own country. It was clear that his views followed the Communist approach to the question" ${ }^{47}$ One added to the ASIO list was a John Fisher, who had contact with Hromádka previously in Czechoslovakia and wanted to catch up with him. As a contact of Ric Throssell, son of well-known communist Katherine Sussanah Pritchard, Fisher was of interest. ${ }^{48}$

\section{Australian branch of the World Council of Churches-1965}

In 1958 Hromádka had written to the Central Committee of the Communist Party of Czechoslovakia, taking up an invitation to all Czechs to comment on the construction of the state. In that memorandum he stated that he regarded himself as "a co-worker" beside the communists, but believed that being a member of the party should not privilege them above "all those workers, farmers, educators and men of letters" who were needed to assist "Communists to shoulder the burden of the tasks facing them". Hromádka "recognised the reasons inducing the Communist Party to rid our public life of all vestiges of superstitions and lifeless religious traditions and in particular of all attempts to use the Church and religion for false restorative aims". His church "took the purification of the Church and religious thinking very seriously". Hromádka repeated his claim that he "cannot complain of even the slightest attempt to restrict my intellectual or public activities or my teaching". But "I know dozens of people who work in schools, public institutes and public life...who are being forced...to give up their faith...and their membership of the Church". He decried that such people had to announce to their Evangelical Czech Brethren congregations that they had to quit them in order to retain their much-loved position as educators. Hromádka also cited instances where Brethren members were afraid to visit their pastor during daylight hours, as it "might jeopardise their jobs". As well there were entire towns where surveillance was carried out to identify those who followed a religious path and there was discrimination in obtaining places in schools against any from a religious family. Hromádka felt the school education did not provide children with the inner convictions based on religious traditions which would enable "the zeal for truth and the goals for socialist society". He ended 
with an offer to meet and discuss any problems the Party may have with his church. So it would seem that all was not quite as favourable in his country as Hromádka had portrayed it when he was in Australia. ${ }^{49}$

The liberalisation of Czechoslovakia under Alexander Dubcek in 1968 gave hope to those who wished to live independently of the USSR. However reservations were held regarding those who had co-operated with the communist regime, such as Hromádka. In 1965 the ACC sought reaction from the Prime Minister's Department for approval in principle for two representatives of the Ecumenical Council of Churches in Czechoslovakia to visit Australia. ${ }^{50}$ The Department of Immigration was advised there was no security objection to this invitation being issued. ${ }^{51}$ Both Hromádka and Milan Opočensky went ahead with arrangements to visit. Hromádka applied for a travel visa for Australia and New Zealand, and included his wife who was to accompany him; the stated aim was to visit "Churches and Theological colleges". ${ }^{52}$ A cable was sent on 7 October from the Australian High Commissioner in London to the Department of External Affairs seeking advice regarding issuing visas to the Hromádkas noting that "In June 1956 ... applicant reached notoriety in Australian press as being pro-communist". ${ }^{33}$ The application for Hromádka was forwarded to the Director General of ASIO to approve the visa. A four-page hand written negative summary was forwarded to Spry, which claimed that Hromádka would again cause problems by espousing the "glowing picture of the sound leadership of the Government (of Czechoslovakia) and the tremendous and glorious strides his country was making towards great prosperity in conditions of democracy and freedom" as he had done to a meeting in Sydney in 1956. Reference was also made to Hromádka's stated opinion at that time that Petrov was a traitor. The agent compiling this summary considered "Hromádka identified himself completely with the Communist regime in Czechoslovakia". ${ }^{54}$ A vetting report was also prepared. ${ }^{55}$ The Director General decided that security clearance would not be given to Hromádka, since "he could only be considered a risk" ${ }^{56}$ This unwelcome decision was never conveyed, either to the ACC or Hromádka, as the ACC advised the Department of Immigration that they had "received from the Council in Czechoslovakia, word that this visit had been postponed 'due to present situation". The ACC hoped "to be able to renew the invitation at an appropriate later date". ${ }^{57}$

Whatever the reason for the change of heart from the Ecumenical Council of Churches in Czechoslovakia in 1965, Hromádka underwent qualms regarding his support for the Soviet Union, when it sent troops into Czechoslovakia in August 1968. The "Prague Spring" was over. Hromádka voiced his objection to this invasion of his country through a letter to the Soviet Ambassador. In it - after citing his credentials as a Lenin Peace prize recipient, that he and his wife had visited Russia many times, and that he had "many friends in the Soviet Peace Committee and the Russian Orthodox Church" - Hromádka recorded that:

In the past few years I have felt more and more disquieted by the feeling that in our State, the old pre-January regime was diminishing the affection of our people for the Soviet Union, our Communist Party was losing its authority and the very structure of our socialist society was paralysed by the political, economic and cultural ability of the Party and State leadership.

Hromádka went on to praise "the process of renewal which started in January 1968" (the "Prague Spring"). He had claimed many times that he did not consider Soviet intervention would happen in his country "because I valued so highly the statesmanship and wisdom of Soviet Political leaders". He stated "the Soviet Government could not have committed a more tragic error...Only a speedy withdrawal of the occupying forces can partially diminish our common disaster" ${ }^{8}$ In Moscow, where he and his wife were receiving medical treatment courtesy of the USSR, Dickie came out to support the "preservation of socialism and maintain the unity of the socialist state". 
While the WPC backed the Soviets, on a motion moved by Isabelle Blume, Co-ordinating President, and seconded by the Secretary General, Hartley reported that there was dissent. ${ }^{59}$

A few days later, before the meeting of the Working Committee of the CPC that was to decide "the hard task of coping with the occupation of the Czechoslovak Socialist Republic by socialist states, and on taking a stand on it", Hromádka reflected that his letter to the Soviet Ambassador was "written at the moment of greatest emotion and with feelings of great bitterness". He needed to explain his position as President of the CPC. He had encountered from the renewal period commencing in January 1968 two interpretations of his actions over the past two decades.

Many friends, especially abroad, are coming to see me and congratulate me on certain results of my activities. But many people, especially at home and in my own Church, are discovering in me an old quizling, a man of the old Stalinist era, and are calling me to account. One of my young former students accused me in a letter that, because of my positive attitude to communism and the USSR and at home, 'I had led Czech Protestantism to moral disintegration, to a spiritual and political disintegration. ${ }^{60}$

In a long résumé of events Hromádka claimed that there was a "tremendous difference between our Czechoslovakian situation of August 21 and the Hungarian events of October 1956". In Hungary there was a "chaotic situation" with "bloodshed, loss of life and a divided nation...some loud voices called for a renewal of the capitalistic order". In Czechoslovakia,

the unity of the people was strengthened from hour to hour; the trade unions, the working class, the farmers, the Army, the Public Security, the People's Militia, the intelligentsia, the youth, Czechs, Slovaks, and other nationalities were closely gathered about the Communist Party and the deported statesman...The week between August 21 and 27 is a glorious part of our history. The unity of our nation in the presence of tanks and machine-guns grew in strength day by day. ${ }^{61}$

Hromádka claimed that the "change in our political life after January 1968 was a revolutionary step forward". He also realised that now the "trustworthiness of the Christian Peace Conference was at stake". He stressed the need progress through "self-criticism to courage". ${ }^{62}$ What is clear is that Hromádka, though heartbroken by the incursion of the Warsaw Pact troops into Czechoslovakia, still maintained his Christian-Marxist beliefs. Moreover, his Australian disciples could not bring themselves to condemn the invasion or alter their world view, that an amalgam of Christianity and socialism was the way forward.

In the aftermath in 1969 the secretary of the CPC, J. N. Ondra, was forced to resign. While Hromádka was not asked to resign, he did so, in support of Ondra. Existing Western regional CPC were disbanded, but Assemblies were still held in 1971 and 1978, with "increasing participation of Third World delegates whose expenses are fully met, if need be, by the CPC". It was evident that the Sixth All-Christian Peace Assembly, held in Prague from 2-9 July 1985, was following the model adopted after the "CPC Crisis" of 1969, in that it was "more than possible for participants to learn nothing of the local political, social and cultural setting which must inevitably condition the Christian Peace Conference in Czechoslovakia". However, Ondra was "rehabilitated after long exile", and after Hromádka died in 1969, his widow was elected an honorary vice-president at the Conference. ${ }^{63}$ In Australia, clergymen such as Rev. Hartley continued their support for the USSR. Hartley was involved in the welcome and inspection of the Soviet Whaling fleet to Melbourne in April-May $1964 .{ }^{64}$ 


\section{Conclusion}

With the benefit of hindsight it is easy to classify as unrealistic those like Hromádka who believed in the possibility of co-operation through churches, for the cause of peace, across the East-West divide in a world where political differences seemed insoluble. But worthy men could be selfdelusional and unable to rid themselves of their utopian dreams. The Australian Peace Parsons reflected the same values as Hromádka, and possibly the same naivety. However, the attitude of those in the West who believed that change was impossible, and that those who attempted reconciliation were little short of being traitors was also mistaken. The influence that hard-line clerics, such as McIntire, exerted across the globe to accentuate bitterness that prolonged the Cold War, cannot be over emphasised. In any event, working for peace became a suspect occupation, where there was a plethora of individuals, organisations and nations all striving to implement their own conception of peace to the world.

Dr Doris LeRoy gained her PhD for the study of Anglican attitudes in Australia to communism in the early Cold War from Victoria University. Her interest is in the nexus of Religion and Politics.

\section{Endnotes}

${ }^{1}$ See Helen Cameron, "Seventy Years of the Evangelical Church of Czech Brethren (1918-88)," note 5, accessed 16 November 2013, http://www.biblicalstudies.org.uk/pdf/rcl/17-3_230.pdf; J. L. Hromadka, The Church and Theology in Today's Troubled Times (Prague, 1956). NB The accent on Hromádka's name was often not used in cited material.

${ }^{2}$ Ibid. note 5. S. R. Rican, 50 let Komenskeho evangelicke bohoslovecke/akulty v Praze, 54. Quoted in Dorothea Neumarker, Josef L. Hromtidka, Theologie und Politik in Kontext des Zeitgeschehens (Munich: 1974) 120.

${ }^{3}$ Paul Bock, "The Dulles-Hromadka Encounter Revisited," Occasional Papers on Religion in Eastern Europe - OPREE, Vol XI, No 3 (May 1991) 37-42.

${ }^{4}$ Geoffrey Beck, "Observer's Report on the Prague Christian Peace Conference", Chronicle, http://www.biblicalstudies.org.uk/pdf/rcl/13-3_335.pdf,335.

${ }^{5}$ Edith Temple Roberts, “Communist Hold on 'Christian’ Peace Movements," http://osaarchivum.org/files/holdings/300/8/3/text/17-1-95.shtml. For a discussion on communist front organisations, see Richard Felix Staar, Foreign Policies of the Soviet Union (Hoover Institution Press, Stanford CA, January 1991), 79-101 esp. 79-80.

${ }^{6}$ See Doris LeRoy, "Pyrrhic Victory? The 'Red Dean' Visits Australia” (Honours Thesis, Victoria University, 2006).

${ }^{7}$ Douglas Jordan, Conflict in the Unions: The Communist Party of Australia, Politics \& the Trade Union Movement, 1945-60 (Resistance Books, Sydney, 2013), 230-231.

${ }^{8}$ Doris LeRoy, "Anglicanism, Anti-communism and Cold War Australia" (PhD diss., Victoria University, 2010), http://trove.nla.gov.au/work/38883583?l-format=Thesis\&q=LeRoy+\%282010\%29\&c=book.

${ }^{9}$ Staar, Foreign Policies, outlines the US position.

${ }^{10}$ See Robert McArthur, "Locating Christ in a Communist World: The Reverends Frank Hartley and Victor James as Political Travellers,” Australian Historical Studies 40, no. 2 (2009), 178-196. 
${ }^{11}$ Marion Hartley, The truth shall prevail : the Rev. Cr. Francis John Hartley, B.A., B.D.: a noble life in quest of truth, reconciliation and peaceful co-existence / a biography by his wife Marion Hartley (Melbourne: Spectrum, 1982), 146-147, 155, 166.

${ }^{12}$ Cited in Robert Iain McArthur, "Christ and the Cold War: an exploration of the political activism of the Reverends Frank Hartley, Alfred Dickie and Victor James, 1942-1972” (PhD diss., University of Melbourne, 2007), 138.

${ }^{13}$ LeRoy, “Anglicanism," 160-163.

${ }^{14}$ Carl McIntire, History of the ICCC, http://www.iccc.org.sg/.

${ }^{15}$ LeRoy, "Anglicanism," 161-163.

${ }^{16}$ Ibid., note 769, Anglican, no. 108, 3 September 1954, 6.

${ }^{17}$ Renate Howe, A Century of Influence: The Australian Student Christian Movement 1896-1996 (Sydney: UNSW Press, 2009), 272-273. It is probably for this reason that the Hromádka meetings do not receive attention in Howe's history of the ASCM.

${ }^{18}$ Keith Rayner, "There is work for every Christian here - The Churches are combining in a world peace drive," Brisbane Courier-Mail, 26 March 1954, 2.

${ }^{19}$ Howe, A Century, 272.

${ }^{20}$ LeRoy, “Anglicanism," 163, note 770, ACR, Rev. D. W. B. Robinson, "Josef Hromadka, What does he stand for?", 19 August 1954, 3,12.

${ }^{21}$ Ibid., 165, note 775, Anglican, vol. 109, 10 September 1954, front page.

${ }^{22}$ Ibid., 165, note 776, Anglican, vol. 109, 10 September 1954, 4.

${ }^{23}$ Ibid., 166, note 778 “An Interview with Dr J. S. Moyes. Bishop of Armidale”, Anglican, vol. 110, 17 September, 1954, 9.

${ }^{24}$ National Archives of Australia (henceforth NAA), A6119, 2622, esp. folios 43, 46-8, 56, 59-60, 62,67-8, 79-80, 84, 94-5, 111, 142-3, 147-149, 152, 154, 160, 183-6.

${ }^{25}$ See Phillip Deery, "War on Peace: Menzies, the Cold War and the 1953 Convention on Peace and War", Australian Historical Studies, no. 22 (October 2003): 248-69.

${ }^{26}$ J. E. Owen, Road to peace: an experiment in friendship across barriers (Melbourne: Hawthorn Press, 1954), 4-22.

${ }^{27}$ Michelle Cavanagh, Margaret Holmes: the life and times of an Australian peace campaigner (Sydney: New Holland, 2006), 154-155.

28 "Peace and Goodwill Assembly-Professor Hromadka-Extract from NSW 'Q" report dated 18.8.1954", 157, NAA A6119, 2622.

29 "South Australia. Annual State Conference of the C. P. of A. 17-19 September 1954, Dr Joseph L. Hromadka, 7 October 1954" 172, NAA A6119/2622.

30 "Student Uproar over Clergyman", 86; "Peace man booed", 121; "Peace and Goodwill Assembly held in Sydney and Melbourne $10^{\text {th }}$ to $20^{\text {th }}$ September 1954", 175-180, NAA A6119, 2622. The Roman Catholic Newman society organised the meeting at the University.

31 "Hromadka's Rowdy Melbourne Reception", 115, 179, NAA A6119, 2622.

32 "Hostile reception for Hromadka," Canberra Times, 17 September 1954, 1.

33 "Wild crowd wrecks 'peace' talk," Argus, 17 September 1954, 1. Hill was a supporter of Eric Butler, an Anglican who formed the League of Rights, a racist, sectarian, anti-communist organisation. Hill issued a "How to vote" pamphlet from St Mark's vicarage, identifying himself as a Church of England Vicar who advocated putting Dr Evatt's party and the communists last in the 1955 State election. See "A Church of England's Vicar's view on the Victorian Elections: A warning on the Sectarian Question", issued by the 
Victorian League of Rights, authorised by Eric D. Butler. Butler met Spry of ASIO in Hill's vicarage. See "Eric Butler's Lunch with Malcolm Fraser", ALOR, The Australian League of Rights, 7 October 1994, http://www.alor.org/Volume30/Vol30No38.htm.

34 "Cleric Tried to ensure a Fair Go", Herald, 17 September 1954, 1, 7.

35 "Peace and Goodwill Assembly held in Sydney and Melbourne $10^{\text {th }}$ to $20^{\text {th }}$ September 1954", 179, NAA A6119, 2622.

36 "Church and Nation - The Man in the Street", Anglican, vol 111, 29 September 1954, 4.

37 "Rev. Geoffrey Lindsay Locksley", 276-277, NAA 6199, 2622.

38 "Assembly of Papua Ekalesia (L.M.S.) Port Moresby - Director General of ASIO to Regional Director for the Territory of Papua and New Guinea, October 22, 1962", 8, NAA A6199, 2623.

39 "Professor Joseph HROMADKA, Travel Officer "C" Section to PRINCIPAL SECTION OFFICER B.1. October 8, 1954" 161, NAA A6119, 2622.

40 "Prof. Hromadaka, Berlin Memo No. 175 from W. B. Pritchett, Secretary to Secretary, Department of External Affairs, Canberra-Translation from a statement 'At the Service of Humanity' in Neue Zeit, 27 November 1954 by Professor Hromadka regarding his impressions of America and Australia”, 204-205, NAA A6119, 2622.

${ }^{41}$ Wentworth to Spicer October 7, 1954,158, 166: "Memo to Director ASIO from Secretary, Attorney Generals Department, 22 October, 1954", 167: "Memo to Secretary Attorney General's Department from Director General, ASIO",168: "Spicer to Wentworth, 29 November 1954", 199, "Letter from Wentworth to R G. Casey 3 December, 1954”, 199 : “Letter to Wentworth from R G Casey, 8 December, 1954”, 200, "Memo to Secretary, Department of External Affairs from C. F. Spry, Director General of Security, 16 December, 1954”, 187, NAA A6199, 2622. Wentworth was well known for his constant requests for information on those he suspected as being communist.

42 "Record Crowds hear Church Leaders" ACR vol 21, no. 3, 16 February 1956, 1.

43 "Voices from Europe", ACR, vol 21, no. 3, 16 February 1956, 4. Also "Debelius and Hromadka, Christians who do not agree”, 229, NAA A6119, 2622.

${ }^{44}$ Ibid., 200, note 926, Douglas Dargaville "WCC Executive Consultation, 1956" unpublished notes. I thank Rev. Dargaville for allowing me access to this material.

45 “HROMADKA Josef Prof.", 105, NAA A6119, 2622.

46 "Protest Rallies Planned. Czech Cleric's Visit Opposed January 22 1956", 216: "Facts sought on Church Council", (Mercury January 23, 4)", 217, NAA A6119, 2622.

47 "Meeting of Czechoslovakian Community in Sydney, February 22 1956", 271: "Evaluation - Remarks New South Wales - Discussion", 274, NAA A6119, 2622.

48 "NSW John FISHER Jan. 20, 1956”, 266, NAA A6199, 2622.

${ }^{49}$ See J.L. Hromadka, "A Letter to the Central Committee of the Communist Party of Czechoslovakia", 5 May 1958, in The Field is the world: selected writings from the years 1918-1968/ Joseph Hromádka, edited and prefaced by Milan Opočensky (Prague: Christian Peace Conference, 1990), English-illustrated edition, 303-310.

50 "Proposal by the Australian Council of Churches to invite Czechoslovakian Church Leaders. Letter to Secretary, Prime-Minister's Department from Secretary, Department of Immigration, August 18, 1965”, 15 16, NAA A6119, 2623.

51 "Proposal by the Australian Council of Churches to invite Czechoslovakian Church Leaders. Letter to Secretary, Department of Immigration, from C.F. Spry, Director-General of Security August 26, 1965”, 17, NAA A6119, 2623. 
52 "Application for Visa - British Embassy Prague", 41-42; "Dr Milan Opocensky Dr Josef Hromadka and wife - Memorandum for headquarters ASIO from G.R. Richards October 15 1965”, 43, NAA A6119, 2623. 53 "Dr Josef Hromadka to Trade, PM's dept and ASIO, from Australian High Commissioner, London October 7 1965”, 21, NAA A6119, 2663.

54 “ASIO Minute paper Joseph Hromadka, October 26-28 1965”, 27-33, NAA A6199, 2623.

55 "Secret and Personal - Dr Josef Hromadka ASIO 'vetting' report November 1965" 33-34, NAA A6119, 2623.

56 "Dr. Joseph Hromadka, Czech - Letter to Secretary, Department of Immigration from Director-General, ASIO November, 1965”, 35, NAA A6119, 2623.

57 "Letter to Mr P.R. Haydon, Department of Immigration from Rev. J.R. Neal, Australian Council of Churches 22 October, 1965”, 38, NAA A6199, 2623.

${ }^{58}$ J L Hromdaka, "Letter to the USSR Ambassador, August 22, 1968", in Opočensky, The Field is the world, 428-429.

${ }^{59}$ McArthur, "Christ and the Cold War", 218.

${ }^{60}$ J. L. Hromadka, "New Questions before the Working Committee Meeting" in Opočensky, The Field is the World, 429-445.

${ }^{61}$ Ibid.,439.

${ }^{62}$ Ibid., 443.

${ }^{63}$ Geoffrey Beck, "Observer's Report on the Prague Christian Peace Conference," Chronicle, http://www.biblicalstudies.org.uk/pdf/rcl/13-3_335.pdf, 335-336. Beck was an observer at the ACPC on behalf of the British Council of Churches.

64 "HARTLEY, Francis John, 4 May 1964", 127, "Soviet Whaling Fleet to visit Melbourne April/May 1964)," 140, 143, NAA, A6119, 1104. 
David Faber, “'Today We Own the Streets': The Adelaide NoWar Rally of 16 February 2003. A Participant Observer Memoir", Proceedings of the 14th Biennial Labour History Conference, eds, Phillip Deery and Julie Kimber (Melbourne: Australian Society for the Study of Labour History, 2015), 83-92. ISBN: 978-09803883-3-6.

\section{“Today We Own the Streets": The Adelaide NoWar Rally of 16 February 2003. A Participant Observer Memoir}

\section{David Faber ${ }^{*}$}

On 16 February 2003 as war clouds gathered over Iraq, some ten per cent of the metropolitan population of Adelaide from across the political spectrum gathered to protest the international lurch towards military conflict. This was the largest political demonstration in South Australian history, larger even than the historic Moratorium March against the war in Vietnam (though not of course more important). What follows is an historical account of how the antiwar movement of 2002-2003 was organised by the NoWar collective, and a discussion of its historical legacy from the personal perspective of a participant observer, the designated historian of the movement. The qualification "personal" is necessary because, no matter how seriously the historical obligation of objectivity is taken, each individual activist's experience of the movement is different. Indeed no first person dimension of that historical moment could be captured otherwise. In addition, my recollections have been squared with those of over a dozen other activists, most of them prominent in one way or another.

It is first necessary to reconstruct the general climate of opinion within the NoWar collective. In 1996 the era of Labor Hawke and Keating governments came to an end and John Howard and the Liberals took power. The neo-liberal "reform" tendencies that animated these Labor administrations were redoubled with the change of office. The concerns of vested interests about perceived public and institutional "reform fatigue" became a thing of the past. In foreign policy the change of the guard signified little enough, as both major parties were committed to the US alliance, leaving disenfranchised critics to the left who favoured a more independent foreign policy in the tradition of Evatt and Whitlam. In his first administration, with the encouragement of the Murdoch press, Prime Minister Howard focussed primarily on domestic policy, oppressing the poor by introducing "mutual obligation" into welfare policy. He also aggressively took on the defensive power of the industrial flagship of the Maritime Union of Australia in the working class citadel of the waterfront, with mixed results. Even so Howard's deft dog whistling of conservative concerns, particularly national unity and the ethnic composition of the country, had a way of morphing from an internal to an external policy focus as his "comfortable and relaxed" Australia became increasingly paranoid and jingoistic over the emerging refugee influx, especially after the criminal attacks of 11 September 2001 on US targets and the resulting declaration by the Bush administration of a "War on Terror". Even prior to this Howard, a declared disciple of Menzies, had revived his deference to our great and powerful friends, America and Great Britain, insisting in 1999 that Australia had a role as deputy sheriff in our region. This did not go down well with our near neighbours. For these reasons by 2002 Howard was more than ever a bete noir for the left wing alternate constituency, which was the counterpart of his consecutive parliamentary majorities. ${ }^{1}$

By the time of President Bush's notorious first State of the Union address on 29 January 2002, in which he lumped together as an "Axis of Evil" three admittedly notorious regimes that 
had nothing to do with Al-Qaeda, the US had already led a coalition including British and Australian forces against the Taliban in Afghanistan, which had refused to hand over or permit hot pursuit of Bin Laden. These developments had early attracted small protests in Adelaide, in which I had not participated, thinking on Hobbesian grounds that the US was probably entitled to respond militarily to the $9 / 11$ provocation as an act of war. I later came around to the view of Gore Vidal that the outrage was best understood as a criminal act which required police intelligence rather than the blunt force of a full scale invasion. The eventual failure of the coalition to capture Bin Laden, who escaped to live clandestinely under the protection of the Pakistan intelligence service for a decade, confirms, I believe, the justice of this more acute approach.

Bush's indiscriminate bellicosity alarmed me and millions of others. Indeed I always said Bush, Blair and Howard were the best recruiters the peace movement had ever had. It became painfully apparent that Bush and his neo-conservative and filo-Zionist advisers, like Paul Wolfowitz and Richard Perle, were obsessed with following up Bush senior's unfinished business in Iraq. This was a regime with which U.S exponents like Donald Rumsfeld had been deeply complicit during the Ba'athist regime's murderous war of attrition against fundamentalist revolutionary Iran. Imperialistic neo-conservative dreams of reorganising the Middle East at gunpoint to secure oil reserves and suit Zionist regional ambitions ${ }^{2}$ were clearly opportunist. They had nothing to do with opposing terrorism and indeed would only lend it legitimacy. The supposed arsenal in Saddam Hussein's hands of so called "Weapons of Mass Destruction" after his military assets had been bombed to perdition during Operation Desert Storm was incredible, had all the hallmarks of wanton self-delusion, and was not verified by Australian intelligence. ${ }^{3} \mathrm{We}$ in the peace movement mocked the whole dubious public relations exercise as being based on "Words of Mass Deception".

Nevertheless it needs to be remembered that many decent people were taken in at the time by this official propaganda with its bold and brazen pretence of accurate intelligence. I recall asking a medical specialist of my acquaintance, for whose intelligence I had the greatest respect, what she thought of the looming war, knowing her to be temperamentally pacifist with a profound distaste for violence and human slaughter. To my naïve surprise she said she thought it all depended on whether Saddam Hussein had weapons of mass destruction. We were offering resistance to a formidable officialdom, whose views were being magnified by an uncritical mainstream media, so I really shouldn't have been caught so off guard.

The roots of opposition to Washington's designs went back to the Gulf War and beyond. I for example had first met political staffer and Middle East solidarity activist, Mike Khizam, on campus at Adelaide University in 1982, opposing apologists for the war crime of the Sabra and Chatila massacres in Beirut during Ariel Sharon's invasion of Lebanon. Other activists like Stephen Darley were prominent organising the Palm Sunday peace rallies of the 1980s. I lent Mike a very modest hand in protesting the 1991 Gulf War and Prime Minister Hawke's dispatch of Australian naval vessels to participate in it. This was when the first manifestation of NoWar was born, the brand originally conceived as an acronym for Network Organizing Against War And Racism (NOWAR). ${ }^{5}$ This $20^{\text {th }}$ century organisation, sometimes referred to short-hand as NOWAR I, bequeathed an historical legacy, some activists, a contact list and some funds to the successor $21^{\text {st }}$ century organisation. Some NoWar activists in 2002-2003 were to be of Vietnam War vintage, including myself. ${ }^{6}$ As the rhetoric ratcheted up during 2002, war psychology came to animate proponents and opponents alike. The looming conflict brought forth its own antagonists. Mobilisation got under way on 17 September 2002 in a hired meeting room at the Pilgrim Uniting Church in Flinders Street, filled to capacity by well over thirty representatives of peace, human rights and social justice organisations from across the religious and secular divide, called together by the venerable Australian Peace Committee SA Inc. The Committee, led in Adelaide amongst others by veteran labour movement and peace activists Don Jarrett, Sue Gilbey, Irene Gale and 
the late Ron Gray, dated from the early Cold War on the national level. ${ }^{7}$ Don's labour movement activism had begun decades before in the communist Eureka Youth League. ${ }^{8}$ Irene had begun her political activism even earlier at the age of six by holding a concert with her sisters to raise contributions for the fight of Republican democracy against fascism during the Spanish Civil War. Don had moved from the chair at the 2002 APC Annual General Meeting, which was addressed by an Islamic Women's Association exponent, that a NoWar organisation be set up. Among those represented at Pilgrim Hall were the Catholic and Uniting Churches, the Medical Association for the Prevention of War, the Women's International League for Peace and Freedom (celebrating its Great War centenary in 2015), Socialist Alliance and its youth wing Resistance, the reborn Communist Party of Australia (formerly the CPA splinter, the Socialist Party of Australia), unions, some university students and others. While many present were familiar with one another, others had never met before. In an effort to broaden the movement from the APC, Don nominated Mike to chair the meeting. Women's movement exponent and social worker Jeanie Lucas became secretary and took minutes. These pivotal roles were to be later confirmed for the movement's duration, involving a heavy commitment of overtime work. As discussion got under way, Jeanie declared that she wanted to see street marches as big and effective as the Vietnam Moratorium. Debate centred around alternative proposals to set up a writing group and organise a rally. From the chair Mike pointed out that the propositions being advanced in any case entailed expenses and recommended a hat be passed around. At this John McGill doffed his working man's cap, collecting some $\$ 200$ from those assembled. As the venue booking was about to expire, it was immediately resolved to continue elsewhere and accept the invitation of Greens Party secretary Anne McMenamin and decamp to the Party office in Wright Street. There a date of 5 October was set for the first rally, initiating a regular series.

Photographs taken at a subsequent rally on 30 November, which culminated at the Rotunda on the banks of the Torrens, feature the participation of Maugham Church Pastor Reverend Lee Levitt Olsson. Indeed the commitment of the Uniting Church throughout the movement is particularly warmly recalled by Jeanie and other key organisers. Another Christian church which participated was the historically pacifist Society of Friends, with Quaker Brian Arnott being an active participant in the NoWar organising collective. Brian's politics was as progressive as anyone's in the movement. His bona fides were accordingly never questioned by fellow activists, despite most of us being more or less atheist. The matter simply never arose in discussion amongst us. This raises the whole question of Christianity and indeed all religions and the left. At the 1997 Annual Conference of the Australian Society for the Study of Labour History Adelaide Branch, guest speaker Mick Atkinson MHA (now Speaker of the SA House of Assembly) complained that Christians were traditionally looked down on in the labour movement. In reply, thinking of the Palm Sunday peace mobilisation and that around the case of "turbulent priest" Father Brian Gore, ${ }^{9}$ I demurred, claiming I had never known the religious question to be divisive on a left with traditions of addressing itself to all people of good will. Indeed as the late Douglas Jordan noted, "historically...Australian peace movements have characteristically been alliances between middle class activists, often intellectuals or Christian pacifists, and radical socialist or trade union groups" ${ }^{10}$ Certainly this was the case in NoWar. We always studiously avoided offending religious and even political sensibilities in addressing ourselves to the public, and sought involvement from all quarters.

I was attracted to one of these rallies in late 2002 and quickly gravitated to participation in the organising collective. Early on, I ran past Mike the proposition which I subsequently put to the collective that what we were doing, the way we were doing it and the public response we were getting was historic and ought to be recorded in process. Apart from my political identification with opposition to this war I had also been attracted to the movement by my interest as an historian in the theoretical challenges of doing current history as it happened. My offer to act in 
this fashion was accepted by the collective with stationary and photographic costs being paid out of petty cash. Artist Mij Tanith was commissioned to keep a photo-record of a number of the early demonstrations at this time. As the mad march to war gathered momentum our rallies became progressively larger than the norm for Adelaide for many years past, although I remember scripting one small rally called at short notice on Parliament House steps. I persuaded an anarchist acquaintance of mine from Queensland to read Jefferson's preamble to the US Declaration of Independence to point out the vital importance of constructive autonomy in Australian foreign policy, just as the Viet Minh had done when they proclaimed the national independence of the Democratic Republic of Vietnam at Hanoi in August 1945. ${ }^{11}$ I then read from Gore Vidal's recent polemic Perpetual War for Perpetual Peace. ${ }^{12}$ I prefaced the reading with the following remarks:

Gore Vidal, who describes himself as "a narrator of our imperial history" is among the most illustrious living American men of letters and public intellectuals. He says of himself "I think I've always had an up close view of the death struggle between the American republic, whose defender I am, and the American global empire, our old republic's enemy." Gore Vidal has been in love with the democratic ideals of the republic all his life, and has warned about its imperial sins for almost as long. In his writings he seeks to bring the USA with wit and insight back to its senses. If he is anti-American, then so is Mark Twain. We do not feel anti-American in his company. We contend that the belligerent policies of Bush, Blair, Howard, Rumsfeld, Cheney, Rice and Powell are not in the best interests neither of the United States, nor Britain nor Australia.

As a former schoolboy orator and debater, to be able to participate in this way was very gratifying. Mike Khizam watched over the proceedings and I was pleased and relieved when he told me he considered the rally a discrete success. I also wrote throughout 2003 a regular column against the war for the Adelaide University campus newspaper On dit, whose editors, one of whom was an anarchist, were supportive of the movement.

What was so characteristic and effective about the collective mode of organisation? Starting out at around 50 participants, it stabilised at around 80, although Socialist Alliance exponent Lesley Richmond remembers some 120 crowding the Greens Party office on one occasion. Leadership was widely diffused non-hierarchically, the sense of participation thereby generated retaining the enthusiasm of all contributors. Certainly despite their centrality Mike and Jeanie were never invested with the status of Beloved Leaders as per the old left tradition of the Cult of Personality. Nevertheless they were the two principal activists around whom the rest of us chose to revolve, shouldering the burden of unrelenting commitment to keep connected a collectivity which numbered personalities of disparate psychological, cultural and political backgrounds. Not that there weren't personality clashes and moments of dissension. One day for example I was invited to chair the collective, and having a labour movement background addressed the assembled activists as "comrades". A feminist zealot snarled at me "That's sexist!" I had it on the tip of my tongue to point out to her that the term was in fact gender neutral, but thought better of it and ignored her the better to get on with business. On another occasion the same woman objected to me referring to "the Great War", interjecting "How can a war be great?" This time I took her to task, pointing out that World War I was so referred to at the time because of its terrifying scale. It is instructive here to note that Jeanie early issued a warning on such matters at the NoWar meeting of 7 November 2002, under the heading "Harmony".

Jeanie brought out into the open some problems in-group dynamics; group relationships; discord. Disparate ideologies and personalities exist, and this diversity must be accommodated for the sake of the cause: NoWar. ${ }^{13}$ 
But all things considered there was little enough interpersonal friction and sectarianism, personality clashes and political disenchantment. Some liked to think the Adelaide movement was particularly well behaved in this regard.

Most activists pulled together in the common cause most of the time, some in large ways, others in small. A few examples are in order here. Colin Mitchell displayed a literary knack, which amused and gratified not a few of us, for getting letters into the editorial columns of The Advertiser. Veteran of the socialist movement, Renfrey Clarke, gave sage advice. Don Jarrett, who was in due course designated chief marshal of the mega-demonstration of 16 February 2003, was very industrious in the collective's organisational work, drawing particularly on his union links, and considers it a copy book example of how to organise politically in modern society. While I agree with him that the collective was politically successful in mobilising activists and public opinion to ensure that war when it came could not be waged in our name, I do so with some reservations, which I will come to later. All in all the collective mode was appropriate to the given historical moment of high and serious political excitement which obtained as the community addressed the question of war and peace, one of the most important any society can face. To the extent that revolution is not a matter of violence in the streets or the overthrow of constitutional states, but rather the conduct of qualitatively elevated politics on other than a routine business as usual basis, it is no exaggeration to say that we were successfully practising revolutionary politics, whilst being very far from being, as the Howard Government alleged, paid agitators. On the contrary we were all unpaid volunteers, and overworked at that.

The call for a weekend of global protest against the war on the weekend of 15-16 February 2003 had gone out from London and the challenge was picked up by the NoWar collective as soon as it was received. As the great day approached Mike and Jeanie received such a volume of enquiries they estimated some 20,000 might answer the call in Adelaide; sceptical police estimated some 15,000 might turn up. Early on NoWar had advertised rallies in the press, but desisted, finding the investment poor value for money given feedback that most attendees were learning of rallies by word of mouth or email. The issue of again advertising in an uncritical mainstream press many of us felt was complicit in war mongering arose again at this time, and once again the pragmatic decision was made to advertise. We also gained the benefit of free advertising, given the editorial decision of The Advertiser to encourage debate about the ethics of secondary school student participation in our rallies. But early on the Sunday morning as we gathered under Don's stewardship at Wright Street we had no idea that the public transport system was straining to deliver unexpected numbers to the assembly point in Victoria Square. We stewards were all a little keyed up and apprehensive. Rounding the Supreme Court with the others carrying an armful of literature, I was relieved to see a goodly number already in the Square, and proceeded to take up my designated distribution point on the corner of Flinders Street. It wasn't very long before people seemed to be coming from everywhere and all the literature was taken, and it was time to link back with other marshals in the heart of the throng. Time passed very quickly and then the head of the march set off. The police had asked us to keep a traffic lane open, but it proved impossible to contain the crowd as it spread right across King William Street. A steward assisting Don as chief marshal became anxious about this, to the point where Don felt it necessary to calm him down with the firm observation "Today we own the streets!" When the march turned into Grenfell Street on its way to Hindmarsh Square, I headed for our ultimate destination at Parliament House. I don't recall exactly what the state of preparations was when I got there but it wasn't long before the proscenium of the House's steps was a riot of colourful flags and often witty placards and banners with people stretching along North Terrace as far as Pulteney Street.

As the time came to address the rally Mike received a phone request from The Advertiser for a crowd estimate. Perplexed he turned to another speaker waiting his turn, magistrate Brian Deegan, and asked him what he thought. Brian replied that he'd been part of a full house at the 
MCG and that this crowd, stretching as far as the eye could see, looked as big as 100,000, so this became our official estimate, which the press accepted. As it happened I was at the same time at the other end of the steps next to a police sergeant who was asked his assessment: he shrugged and offered the same estimate. Moments later Jeanie, who was always careful to remain behind at our rallies to clean up so that the movement could not be accused of littering, phoned through to Mike the report that the rear of the rally had not left Victoria Square. Mike reported this at Parliament House to the joyous acclaim of the crowd. Brian thinks in retrospect that his was probably a substantial underestimate. ${ }^{14}$

Mike continued to warm up with the crowd with a memorable short speech that directly spoke to the alienation and disenchantment typical of liberal democratic citizens:

If you've had times when you listen to the stupid things that George Bush has been saying or John Howard has said and you think to yourself "Am I the only one who can see they are crazy?", look around you. We are not alone. ${ }^{15}$

He went on to report of the millions who had marched in London, Madrid and Barcelona. He requested the head of the march to move further down North Terrace towards the railway station, but those in the prime positions could not be persuaded to give them up. One young man climbed into a tree to get a better view but fell heavily right in front of me, injuring his coccyx. An ambulance had to be called and was forced to inch its way across the intersection towards him: he was the only casualty of the day. $\mathrm{ABC}$ broadcaster and mistress of ceremonies, Julia Lester, likewise made slow progress through the crowd, arriving only just in time to get proceedings underway. Another ABC broadcaster, Peter Goers, also addressed the throng:

You are the best people in South Australia. You are linked with the world, which wants peace. The right wing governments say we are paid agitators and peaceniks. All we are saying is give peace a chance. Resistance! ${ }^{16}$

The crowd was perfectly peaceful, law-abiding, civil and well behaved. This was not only in keeping with the occasion but just as well, because if the crowd had wanted to loot the city no one could have stopped it, for the CBD was in a gridlock and neither police nor organisers could budge. There were drivers trapped in a parking station in Grenfell Street by the immobile marchers in the thoroughfare. Yet not a pane of glass was broken, and no-one came to blows with frustration; fellow feeling was the order of the day. Participant Dr Marie Longo remembered "the electricity in the air. The sense of community. The pride...[uniting] people [of] all ages, ethnicities, socio-economic status" and recalled how animated conversation was afterwards at the Exeter Hotel "not just about the war, but about life, love and the universe." ${ }^{17}$ There was no mistaking the almost carnival atmosphere of celebration of positive values which had been noted also at earlier rallies, not without some misgivings given the serious business in contemplation. ${ }^{18}$

Speaking of seriousness, the important set piece speeches given, which were only heard because of a reasonable public address system by those in front of Parliament House (those as near as Government House heard nothing), were set in train with a Kaurna Welcome to Country from Auntie Veronica Brody. She proclaimed "a very, very warm welcome to land from your indigenous brothers and sisters of South Australia, who walk with you in support for NoWar!" The crowd was very appreciative, with Julia commenting appositely "You know what attacking a culture means." Peter Coombe then poignantly sang a cappella - the very pertinent Joni Mitchell Vietnam-era peace classic The Fiddle \& the Drum. Then a children and adults' concert scheduled for the following Saturday was announced featuring Humphrey B. Bear and singer-songwriter Abbey Cardwell. Julia gently emphasised that Peter, an active member of the organising collective 
on the arts advocacy side of things, would headline without being didactic, speaking of love to kids. ${ }^{19}$

Then Flinders University lecturer, Dr David Palmer, a dual United States-Australian citizen, was brought to the microphone he had graced to acclaim at previous rallies. To cheers he began:

This war in Iraq is not our war. Bring home now Australian defence personnel. Australia must work with U.N. weapons inspectors, not against them as the current U.S. government is doing. The game is up George! We are sick and tired of your lies and deception. We don't believe dropping 4,000 bombs over forty-eight hours during Phase II of Shock and Awe, will liberate Iraqis. The embargo hasn't removed the dictator Saddam Hussein. War will only increase his legend and kill tens of thousands. This is a war for oil, although the Three Amigos deny this...Iraq had the second largest proven oil reserves in the world.

David continued by quoting a recent Manchester Guardian interview with former Adelaidean Rupert Murdoch, to the effect that "Bush was behaving very morally, very correctly and will follow through. We can't back down now. Bringing the price of oil down to $\$ 20.00$ a barrel would be one of the war's main benefits, the best outcome for the world economy, better than a tax cut." Any Security Council endorsement of the wilful, self-appointed Coalition of the Willing would destroy confidence in the UN. The day before weapons inspector, Hans Blix, had reported that his team had found no weapons of mass destruction but only some empty chemical munitions which ought to have been declared and destroyed. There was, therefore, no excuse for this war, when as American weapons inspector, Scott Ritter, had demonstrated, isolation and containment of Saddam Hussein was all that was necessary. War and occupation would only replace dictatorship with a puppet regime like the Shah or Marcos or warlordism as in Afghanistan. It would not bring democracy or end terrorism. We were part of the biggest peace movement in history, as shown by massive polling against the war in Spain, Britain, Japan, Turkey, Egypt and elsewhere. War would destabilise the region. Millions of middle class working Americans who remembered the tragedy of the Vietnam War were opposed to Bush's warmongering. One hundred Labor MPs at Westminster had rebelled against the war, and Blair's career was over. We were not powerless, we must overcome our fears. People not politicians had the real power. The global peace movement was just the beginning. That John Howard had dismissed the will of the majority as having no impact upon him boded ill for democracy. What was needed was not war but law enforcement, including prosecution of the Bali bombers; Osama Bin Laden did not after all live in Baghdad. Nelson Mandela had called for Bush to be thrown out of office. David himself had written to long serving liberal Massachusetts Senator Edward Kennedy calling for Bush to be impeached. Howard should resign and call an election. ${ }^{20}$

Next to the microphone was famed author Mem Fox who gave a pithy and passionate address:

Just look at us! There are tens of thousands of us, maybe a hundred thousand, here in great numbers for one great purpose, to stop the slaughter in Iraq along with millions of U.S. citizens and many millions around the world. We don't belong to the Coalition of the Willing, we belong to the Coalition of the Unwilling. We want only to stop this war. Saddam Hussein is a tyrant. But where did he get his chemical weapons?: Donald Rumsfeldt. The hypocrisy is sickening. The coalition of killers claims as few civilians as possible will be killed: but we must stand against this slaughter of the innocents. Don't the Iraqis have human rights? Why ignore them to restore them? Why kill to prevent killing? 
War would only increase the hatred of the fundamentalist fanatics and increase terrorism a hundred fold...

After Mem wound up her speech to thunderous applause, Mike returned to the microphone to ram home some vital points. A witty New York protestor had carried a toothbrush placard demanding "Fight Plaque not Iraq". We had better things to do than fight Third World countries presenting no threat to us. Despite a government fear campaign we had mounted the biggest demonstration in South Australian history, driven by common sense and decency lacking in our leaders. If the impending war went according to plan, however, unlike us its victims would not be able to turn off the TV. War was always a Pandora's box, easier to start than to finish, sowing seeds of hatred between peoples. But whatever happened it would not be conducted in our name. Mike then introduced serving magistrate, Brian Deegan, father of Bali bombing victim and Sturt footballer Joshua Deegan.

Brian spoke from the heart about loss and in the implicit conviction that the Howard Government had exploited and betrayed the Bali bombing victims. ${ }^{21}$ His legal training was evident in his emphasis on the rights and duties of a parent. An evocative close paraphrase ${ }^{22}$ of his moving, essential remarks, by journalist Tracie McPherson, was published the following day in The Advertiser, which is worth quoting in full:

I have a right to love and protect my remaining three children and we should not overlook the fact that these values are shared worldwide. Why should so many Iraqi children be condemned to the same fate as my child and the others in Bali? Bin Laden has succeeded in doing what he set out to do and what we were trying to prevent - we are doing his evil work. I have lost my son as a result of an undeclared war. Our government has cynically depersonalised these people who hold many of the same values we hold so dear. Don't the Iraqis love their children too?

Democrat exponent Ruth Russell also addressed the rally, declaring her intention to go to Iraq as a Human Shield. Collective member Edward Cranswick also went to Iraq on the same humanitarian mission.

The legacy of the rally and the NoWar movement was complex. Clearly the 16 February monster rally had been a great success. Activist resourcefulness had generated an imposing public response. But as most of the collective quietly expected war to break out anyway, there was no triumphalism amongst us, only sober determination to continue our opposition. A few activists were dismayed at the thought of our work being "wasted". I remember being surprised at hearing one activist muse in this sense on the eve of the rally. I realised that I had never thought we were likely to stop the war. My objective had been to politically isolate the proponents of war, make them indulge their bellicosity on their own responsibility. But many thousands who attended the rally were probably less pragmatic and more idealistic in their participation, and their disappointment was a factor in reduced attendances at protests after "Operation Iraqi Freedom" was launched. Mike had boldly predicted on the basis of the Gulf War precedent that after Australian boots hit the ground in Iraq, activist commitment and public support would drop away as the government supported the troops for all it was worth. We of course proposed supporting them by bringing them speedily home. I was somewhat sceptical about Mike's prediction, thinking it a bit drastic, but he proved to be substantially right. This raised the question of our next move. Should we pack up and go home having done our dash? Or should we persevere in the hope of evolving a sustainable anti-war organisation? The latter option was preferred, the question was how. This returns us in conclusion to the question deferred above of the limitations of the collective, which were most evident in the attempt to carry on after the rally. 
It is a key element of the concept of a participant observer that he or she intervene to shape and develop the processes under observation. Unaware of this theoretical imperative at the time, I had nevertheless acted to gain a hearing as a constructive critic of the collective's business management methods. At the NoWar organising meeting on 8 April 2003 I circulated a one page discussion paper with the wordy title An opportune minimum of accountable democratic structure: a proposal. Despite undiplomatically describing the collective as a dysfunctionally undifferentiated committee of all business, it was surprisingly accepted as a basis of reorganisation under the leadership of an executive steering committee. Unfortunately this process bogged down as a bored collective dwindled, legal advice to adopt and adapt a model constitution from the Associations $\mathrm{Act}^{23}$ being rejected in favour of laboriously reinventing the wheel by developing one clause by clause. This debate degenerated into an ideological confrontation regarding "direct" versus "representative" democracy between Stephen Darley on the one hand and myself and Bruce Hannaford on the other. I ended up retiring to my studies and the ranks of the movement after the first NoWar Annual General Meeting later that year, having been nominated media officer by Brian Arnott and losing to incumbent Green exponent Anne McMenamin by one vote. The NoWar executive worthily transacted much peace business in the name of a declining activist membership base until it was wound up in 2008. It responsibly contributed, for example, to the cost of the clean up of the Opera House after impolitic Sydney activists had daubed it with the NoWar slogan. During commemoration of the tenth anniversary of the February 2003 rally it was clear that veteran activists would do it all again in like circumstances.

Dr David Faber is a labour historian and Executive Member of the Australian Society for the Study of Labour History Adelaide Branch. He is an Executive Member with Jeanie Lucas and Mike Khizam of the Australian Friends of Palestine Association SA.

\section{Endnotes}

\footnotetext{
${ }^{1}$ This reconstruction of the historical context of the events of 2002 and 2003 is buttressed by readings of M. Kingston, Not Happy John!: Defending Our Democracy (Melbourne, Penguin: 2004); R. Manne (ed), The Howard Years (Melbourne: Black Inc., 2004); D. Marr \& M. Wilkinson, Dark Victory (Sydney: Allen \& Unwin, 2003); and C. Aulich \& R. Wettenhall (eds.), Howard's Second \& Third Governments: Australian Commonwealth Administration 1998-2004 (Sydney: UNSW Press, 2005); R. Manne "From Tampa to 9/11: Seventeen days that changed Australia" in M. Crotty \& D. Roberts (eds.), Turning Points in Australian history (Sydney: UNSW Press, 2009); T. Windsor "Going to war the Howard way", The Saturday Paper, 1 November 2014.

${ }^{2}$ See the English translation from the Hebrew by Israel Shahak of Israeli journalist Oded Yinon's "A Strategy for Israel in the Nineteen Eighties" (Belmont, Mass.: Association of Arab-American University Graduates Inc., 1982). The essay was originally published in Kivunim (Directions) A Journal for Judaism \& Zionism, No.14 February 1982. See also the collection of essays Neo-Conned Again (Vienna, Virginia: Light in the Darkness Publications, 2005).

${ }^{3}$ Margaret Swieringa, "Howard ignored official advice on Iraq's weapons and chose war", The Age, 12 April 2013. Swieringa was the public service secretary from 2002 to 2007 of the ASIO, ASIS and Defence Signals Directorate committee of the Commonwealth parliament. These Australian agencies took foreign intelligence into account in their assessments.

${ }^{4}$ See undated flyer entitled "WMDs...W Words of Mass Deception", which from internal evidence may have been issued as early as February 2003; in NoWar Archives in the State Library of South Australia. Personal contact details of individual activists have been with-held for privacy reasons, and remain in the designated custody of Jeanie Lucas.
} 
${ }^{5}$ The acronym embodied the belief that official appetite for war in the Middle East was racist and Islamophobic. The fully capitalised acronym was eventually dropped in favour of the more readily understood NoWar slogan after public feedback that the earlier acronym was obscure, but this did not occur until after the success of the rally of 16 February 2003. Here the more accessible form is used throughout.

${ }^{6}$ At the age of eight, I wanted to march in the Moratorium procession in Burnie, Tasmania, exploiting the credibility of my Cub Scout uniform. My timorous father talked me out of it on the grounds that ASIO might take my photo and compromise my employment prospects.

${ }^{7}$ Sue recalls that the Adelaide branch of the APC grew out of the Jim Gale-led Campaign Against Racial Exploitation and kicked off with a bequest from a veteran Communist. The activism in both organisations of Irene Gale would tend to confirm this account. Testimony, Sue Gilbey, September 2014. For the inauguration of the APC at the national level under the rubric of the Australian Peace Council, see Douglas Jordan, Conflict in the Unions: The Communist Party of Australia, Politics \& the Trade Union Movement 1945-60 (Sydney: Resistance Books, 2013), 61-2.

${ }^{8}$ For an autobiographic profile of Don's labour movement involvement see Movers \& Shakers: Stories of activists who have made a difference in South Australia (Adelaide: SA Unions, 2007).

${ }^{9}$ For a contemporary historical record of the Gore case see A. McCoy Priests on Trial (Melbourne: Penguin, 1984).

${ }^{10}$ See Jordan, Conflict in the Unions, 62.

${ }^{11}$ B. Tuchman, The March of Folly; from Troy to Vietnam (London: Michael Joseph, 1984), 240.

${ }^{12}$ G. Vidal, Perpetual War for Perpetual Peace: How We Got To Be So Hated (New York: Thunder's Monthly Press/Nation Books, 2002), previously published in Vanity Fair in December 2000 but written prior to the presidential election of 7 November. The title derives from the analysis of US foreign policy by American historian Charles A. Beard; see Vidal, 150.

${ }^{13}$ Minutes of NoWar Meeting, 7 November, NoWar Archives.

${ }^{14}$ Testimony of Jeanie Lucas, Mike Khizam and Brian Deegan, January 2013

${ }^{15}$ NoWar Adelaide Rally CD 1, NoWar Archives.

${ }^{16}$ Ibid.

${ }^{17}$ Email, Dr Marie Longo to David Faber, 11 April 2013.

${ }^{18}$ See reported critical comment from a participant at a previous rally regarding a "fair atmosphere", minuted under the heading "Rally Debrief", NoWar Organising Group Minutes, 5 December 2012, NoWar Archives.

${ }^{19}$ NoWar Adelaide Rally CD 1, NoWar Archives.

${ }^{20}$ Ibid.

${ }^{21}$ Testimony, Brian Deegan, January 2013.

${ }^{22}$ That the McPherson quotes were not exactly verbatim is clear from the NoWar recording of Brian's speech; he spoke longer than The Advertiser report suggests. NoWar Rally CD 1, NoWar Archives.

${ }^{23} \mathrm{My}$ recollection is that this excellent advice came from activist Bruce Hannaford and MHA Kris Hanna, both legally trained. 